\title{
Systematic studies in the eucalypts. 11 - New taxa and combinations in Eucalyptus Section Dumaria (Myrtaceae)
}

\author{
K.D. Hill, L.A.S. Johnson ${ }^{\dagger}$ \& D.F. Blaxell
}

\begin{abstract}
Hill, K.D., Johnson, L.A.S. \& Blaxell, D.F. (National Herbarium of New South Wales, Royal Botanic Gardens, Sydney, NSW 2000 Australia ) 2001. Systematic studies in the eucalypts. 11. New taxa and combinations in Eucalyptus Section Dumaria (Myrtaceae). Telopea 9(2): 259-318. New taxa and combinations in Eucalyptus Section Dumaria from Western Australia and South Australia are presented (some species occur in adjacent regions of Victoria and New South Wales). New species described are Eucalyptus capitanea, E. grossifolia, E. singularis, E. laevis, E. pleurocorys, E. trachybasis, E. planipes, E. spreta, E. valens, E. wubinensis, E. assimilans, E. infracorticata, E. redimiculifera and E. paralimnetica. New subspecies are recognised in E. costata F. Muell. (subsp. murrayana), E. leptocalyx Blakely (subsp. petilipes), E. scyphocalyx (F. Muell. ex Benth.) Maiden \& Blakely (subsp. triadica), E. fraseri (Brooker) Brooker (subsp. melanobasis) and E. obtusiflora DC. (subsp. cowcowensis). A new combination is made for E. obtusiflora subsp. dongarraensis (formerly E. dongarraensis Maiden \& Blakely), and circumscription and typification of E. incrassata and E. angulosa are discussed. Multiple entry tables are provided as an aid to identification.
\end{abstract}

\section{Introduction}

New taxa described here are from section Dumaria (as defined by Pryor and Johnson, 1971, with amendments discussed below), occurring mainly in Western Australia and South Australia. All are taxa defined during the studies led by the late L.A.S. Johnson as a part of an evaluation of the classification and relationships of the eucalypts. Several of these taxa are treated as undescribed species or subspecies in the semipopular account of south-western taxa by Brooker and Kleinig (1990). The new taxa discussed both here and by Brooker and Kleinig were delineated by us during a comprehensive revisionary study of the eucalypts, and were freely discussed with Ian Brooker in order to allow their treatment in Brooker and Kleinig. A number of other new species in this section have also been formally described by other workers (e.g. Brooker \& Hopper, 1991, 1993, Nicolle 1997), rendering keys presented by Chippendale (1988) obsolete. Multiple entry tables are provided as an aid to identification and as a supplement to keys presented by Brooker and Kleinig (1990).

Terminology and nomenclature are as in previous papers in this series (see Hill \& Johnson 1994, 1995). Rare or threatened species are allocated conservation status codes according to the system of Briggs and Leigh (1996).

We are acquainted with all the new and related taxa in the field, and all new taxa have been interpreted on the basis of both herbarium collections and field observations of populations in situ. 


\section{Section Dumaria}

Section diagnosed as follows: oil glands in pith (sometimes sparse or absent in series Incrassatae); oil glands absent from bark; outer calyptra shed early; filaments inflexed; anthers dorsifixed, versatile, cuneate (shorter and more cuboid in series Merrickianae, Leptocalyces and Deflexae), apically truncate, regularly radially arranged and apically packed against nectary disc, dehiscing by parallel slits; cotyledons rounded or shallowly obreniform; ovules in 4 rows (4-8 in series Incrassatae).

All species included here are part of section Dumaria, itself a component of the large subgenus Symphyomyrtus (Pryor \& Johnson 1971, Brooker 2000). This section is substantially Western Australian in distribution. The section is characterised by the regularly inflexed filaments with cuneate anthers that are regularly closely packed with their apices appressed to the nectary disc in unopened buds. The group is otherwise highly diverse, and has so far not been clearly demonstrated to be monophyletic. A number of distinctive and clearly defined series are recognisable, however, within the section Dumaria (Table 1). Series Incrassatae, Torquatae, Leptocalyces and Obtusiflorae are discussed separately below.

Table 1. A classification of Section Dumaria

Section Dumaria

Series Incrassatae

Subseries Incrassatosae

Subseries Tetrapterosae*

Series Rigentes*

Series Pimpinianae*

Series Torquatae

Subseries Laevosae

Subseries Corrugatosae

Subseries Torquatosae*

Series Leptocalyces

Series Deflexae*

Series Merrickianae*

Series Obtusiflorae

Series Cometaevallares*

Subseries Ovularosae

Subseries Cylindrocarposae

Subseries Cometaevallarosae

*Not treated in this paper

\section{Series Incrassatae}

Treated as Series Tetrapterae by Blakely (1934: 73) and by Chippendale (1988), but with the inclusion of E. pimpiniana Maiden. The latter was excluded from this series by Brooker and Kleinig (1990), a view with which we concur. Brooker (2000) separated the E. tetraptera group into a separate series on the basis of autapomorphic novelties, ignoring informative grouping characters that clearly place it with the taxa here included in the series.

Series distinguished as follows: oil glands usually present in pith, sometimes sparse or absent; juvenile leaves disjunct, petiolate; anthers angular or somewhat rounded; ovules in varying numbers of rows depending on species; seeds dark brown or black, 
regularly reticulate, irregularly circumferentially winged or flanged, more or less pyramidal or flattened-pyramidal, with winged ribs radiating from the paler, ventral hilum; stomata large and translucent, giving a bluish sheen to the leaves.

Two subseries are distinguishable within the series (Table 2). Subseries Incrassatosae is made up of a number of species that have all been included in a broad application of E. incrassata at some time or other. Several of these have already been clarified (Table 3, and see Chippendale 1988, Brooker \& Hopper 1993), and others are discussed below. The subseries is widely distributed across the 'mallee country' of southern Australia, from south-western Western Australia east to south-western New South Wales and western Victoria (Figs. 2, 3) This account and classification summarises our revisionary studies of this series, although further study of the variation in, and geographic extent of, E. captiosa Brooker \& Hopper is still required. A tabular comparison of characters is provided to facilitate identification within the series, rather than a dichotomous key (Table 4).

Table 2. A classification of Series Incrassatae

Series Incrassatae

Subseries Incrassatosae (E. incrassata sens. lat.)

$$
\begin{aligned}
& \text { E. captiosa } \\
& \text { E. incrassata } \\
& \text { E. angulosa } \\
& \text { E. ceratocorys } \\
& \text { E. costata }
\end{aligned}
$$

subsp. murrayana

subsp. costata

E. capitanea

E. grossifolia

E. singularis

Subseries Tetrapterosae
E. tetraptera
E. stoatei
E. forrestiana
E. dolichorhyncha

Table 3. Published names in Series Incrassatae (accepted names in Bold type, taxonomic synomyms represented by ' $=$ ', nomenclatural synonyms represented by ' $\equiv$ ').

E. incrassata Labill., Nov. Holl. Pl. Sp. 2: 12 (1806).

E. angulosa Schauer in Walp., Repert. Bot. Syst. 2: 925 (1843).

E. cuspidata Turcz., Bull. Soc. Nat. Mosc. 22(2): 22 (1849); = E. angulosa.

E. tetraptera Turcz., Bull. Soc. Nat. Mosc. 22(2): 22 (1849).

E. acutangula Turcz., Bull. Cl. Phys.-Math. Acad. Imp. Sci. Saint-Petersbourg 10: 337 (1852); =

E. tetraptera.

E. costata F. Muell., Trans. Victorian Inst., 33 (1855).

E. forrestiana Diels in Diels \& Pritzel, Bot. Jahrb. Syst. 35: 439 (1904).

E. angulosa Schauer var. ceratocorys Blakely, Key Eucalypts, 174 (1934); E E. ceratocorys.

E. stoatei C. Gardner, J. \& Proc. Roy. Soc. Western Australia 22: 126 (1936).

E. forrestiana subsp. dolichorhyncha Brooker, J. \& Proc. Roy. Soc. Western Australia 56(3): 74 (1974); $\equiv$

E. dolichorhyncha.

E. ceratocorys (Blakely) L.A.S. Johnson \& K.D. Hill, Fl. Australia 19: 508 (1988).

E. dolichorhyncha (Brooker) Brooker \& Hopper, Nuytsia 9: 57 (1993).

E. captiosa Brooker \& Hopper, Nuytsia 9: 55 (1993). 
Table 4. Subseries Incrassatosae (all measurements in $\mathrm{mm}$ ).

\begin{tabular}{|c|c|c|c|c|c|}
\hline Habit & $\begin{array}{l}\text { E. incrassata } \\
\text { mallee }\end{array}$ & $\begin{array}{l}\text { E. captiosa } \\
\text { mallee }\end{array}$ & $\begin{array}{l}\text { E. angulosa } \\
\text { mallee }\end{array}$ & $\begin{array}{l}\boldsymbol{E} \text {. ceratocorys } \\
\text { mallee }\end{array}$ & $\begin{array}{l}\text { E. capitanea } \\
\text { mallee }\end{array}$ \\
\hline Substrate & $\begin{array}{l}\text { noncalcareous } \\
\text { sands, gravels }\end{array}$ & $\begin{array}{l}\text { white sand } \\
\text { over laterite }\end{array}$ & $\begin{array}{l}\text { calcareous } \\
\text { sands coastal }\end{array}$ & $\begin{array}{l}\text { red or white } \\
\text { sand over } \\
\text { sandy loam }\end{array}$ & $\begin{array}{l}\text { red desert } \\
\text { sands }\end{array}$ \\
\hline $\begin{array}{l}\text { Juvenile } \\
\text { leaves }\end{array}$ & $\begin{array}{l}\text { elliptical to } \\
\text { ovate }\end{array}$ & $\begin{array}{l}\text { ovate to } \\
\text { lanceolate }\end{array}$ & broad-elliptical & $\begin{array}{l}\text { ovate to broad- } \\
\text { lancelote }\end{array}$ & $\begin{array}{l}\text { broad-elliptical } \\
\text { to ovate }\end{array}$ \\
\hline Adult leaves & $\begin{array}{l}\text { broad-lanceolate } \\
\text { to elliptical }\end{array}$ & $\begin{array}{l}\text { narrow- } \\
\text { lanceolate }\end{array}$ & $\begin{array}{l}\text { broad- } \\
\text { elliptical }\end{array}$ & $\begin{array}{l}\text { broad- } \\
\text { lanceolate }\end{array}$ & $\begin{array}{l}\text { broad- } \\
\text { lanceolate }\end{array}$ \\
\hline - size $(L \times B)$ & $50-110 \times 9-30$ & $50-70 \times 8-10$ & $80-140 \times 25-50$ & $70-120 \times 10-25$ & $70-130 \times 14-45$ \\
\hline Petiole & terete & terete & terete & $\begin{array}{l}\text { terete to } \\
\text { slightly } \\
\text { flattened }\end{array}$ & flattened \\
\hline Petiole (L) & $15-20$ & $10-20$ & $15-30$ & $20-25$ & $14-30$ \\
\hline Peduncle & flattened & $\begin{array}{l}\text { slightly } \\
\text { flattened }\end{array}$ & $\begin{array}{l}\text { flattened, } \\
\text { broad }\end{array}$ & flattened & flattened \\
\hline Peduncle (L) & $10-28$ & $8-20$ & to 20 & $10-25$ & $18-27$ \\
\hline Pedicel & $\begin{array}{l}\text { terete to slightly } \\
\text { quadrangular }\end{array}$ & $\begin{array}{l}\text { slightly } \\
\text { flattened }\end{array}$ & $\begin{array}{l}\text { terete } \\
\text { to quadrangular }\end{array}$ & $\begin{array}{l}\text { terete, } \\
\text { winged }\end{array}$ & terete \\
\hline Pedicel (L) & $15-23$ & $5-8$ & $3-5$ & $5-8$ & $2-6$ \\
\hline $\begin{array}{l}\text { Buds - size } \\
(L \times B)\end{array}$ & $12-16 \times 4-7$ & $10-12 \times 4$ & $11-17 \times 7-9$ & $9-11 \times 6-7$ & $9-22 \times 6-9$ \\
\hline - calyptra & beaked, ribbed & $\begin{array}{l}\text { strongly } \\
\text { beaked }\end{array}$ & $\begin{array}{l}\text { conical, } \\
\text { not beaked }\end{array}$ & $\begin{array}{l}\text { beaked, } \\
\text { not ribbed }\end{array}$ & $\begin{array}{l}\text { conical, } \\
\text { beaked }\end{array}$ \\
\hline - hypanthium & slightly ribbed & slightly ribbed & coarsely ribbed & ribbed & strongly ribbed \\
\hline Fruits & $\begin{array}{l}\text { cupular } \\
\text { to cylindrical }\end{array}$ & cupular & cupular & $\begin{array}{l}\text { suburceolate } \\
\text { to cylindrical }\end{array}$ & urceolate \\
\hline - size $(L \times B)$ & $8-13 \times 7-13$ & $6-10 \times 8-10$ & $15-25 \times 15-25$ & $17-25 \times 10-15$ & $16-22 \times 12-15$ \\
\hline - ribbing & slight & slight & strong & slight & distinct \\
\hline Valves & to rim level & to rim level & below rim & $\begin{array}{l}\text { deeply } \\
\text { enclosed }\end{array}$ & $\begin{array}{l}\text { deeply } \\
\text { enclosed }\end{array}$ \\
\hline \multirow[t]{2}{*}{ Seeds } & black & grey-black & black & black & $\begin{array}{l}\text { dark grey-brown } \\
\text { to black }\end{array}$ \\
\hline & not winged & $\begin{array}{l}\text { prominent } \\
\text { wing }\end{array}$ & not winged & narrow wing & narrow wing \\
\hline
\end{tabular}


Table 4. Subseries Incrassatosae (all measurements in $\mathrm{mm}$ ) cont.

\begin{tabular}{|c|c|c|c|c|}
\hline & $\begin{array}{l}\text { E. costata } \\
\text { subsp. costata }\end{array}$ & $\begin{array}{l}\text { E. costata } \\
\text { subsp. murrayana }\end{array}$ & E. grossifolia & E. singularis \\
\hline Habit & mallee & mallee & mallee & tree ('mallet') \\
\hline Substrate & $\begin{array}{l}\text { red sand or } \\
\text { sandy loam }\end{array}$ & $\begin{array}{l}\text { red sandy } \\
\text { loam \& } \\
\text { desert sand }\end{array}$ & $\begin{array}{l}\text { laterite or } \\
\text { silicious } \\
\text { sands }\end{array}$ & $\begin{array}{l}\text { sand over } \\
\text { laterite }\end{array}$ \\
\hline $\begin{array}{l}\text { Juvenile } \\
\text { leaves }\end{array}$ & $\begin{array}{l}\text { ovate to broad- } \\
\text { lanceolate }\end{array}$ & $\begin{array}{l}\text { ovate to broad- } \\
\text { lanceolate }\end{array}$ & $\begin{array}{l}\text { ovate to } \\
\text { elliptical }\end{array}$ & $\begin{array}{l}\text { elliptical to } \\
\text { broad-lanceolate }\end{array}$ \\
\hline Adult leaves & lanceolate & lanceolate & $\begin{array}{l}\text { lanceolate } \\
\text { to ovate }\end{array}$ & $\begin{array}{l}\text { narrow- } \\
\text { lanceolate }\end{array}$ \\
\hline - size $(L \times B)$ & $60-110 \times 13-28$ & to $120 \times 15-25$ & $50-120 \times 20-50$ & $70-130 \times 18-20$ \\
\hline Petiole & $\begin{array}{l}\text { terete to } \\
\text { slightly flattened }\end{array}$ & terete & $\begin{array}{l}\text { flattened to } \\
\text { terete }\end{array}$ & terete \\
\hline Petiole (L) & $12-20$ & $15-25$ & $11-26$ & $10-20$ \\
\hline Peduncle & angular, thick & $\begin{array}{l}\text { terete to } \\
\text { slightly flattened }\end{array}$ & $\begin{array}{l}\text { flattened, } \\
\text { broad }\end{array}$ & flattened \\
\hline Peduncle (L) & $12-18$ & $10-20$ & $12-30$ & $15-30$ \\
\hline Pedicel & terete & terete, & terete & quadrangular \\
\hline Pedicel (L) & $3-10$ & $3-5$ & $0-4$ & $5-10$ \\
\hline $\begin{array}{l}\text { Buds - size } \\
\text { (L×B) }\end{array}$ & $9-18 \times 5-8$ & to $15 \times 6$ & $9-17 \times 6-8$ & $9-20 \times 5-8$ \\
\hline - calyptra & $\begin{array}{l}\text { conical, } \\
\text { beaked }\end{array}$ & $\begin{array}{l}\text { conical, } \\
\text { beaked }\end{array}$ & $\begin{array}{l}\text { conical, } \\
\text { beaked }\end{array}$ & $\begin{array}{l}\text { long-beaked, } \\
\text { ribbed }\end{array}$ \\
\hline - hypanthium & slightly ribbed & ribbed & strongly ribbed & strongly ribbed \\
\hline Fruits & $\begin{array}{l}\text { ovoid to } \\
\text { cupular }\end{array}$ & cylindrical & $\begin{array}{l}\text { cupular } \\
\text { to obconical }\end{array}$ & cylindrical \\
\hline - size $(L \times B)$ & $11-16 \times 9-12$ & $9-13 \times 7-10$ & $10-20 \times 9-15$ & $15-20 \times 8-10$ \\
\hline - ribbing & distinct & $\begin{array}{l}\text { slight to almost } \\
\text { smooth }\end{array}$ & distinct & distinct \\
\hline Valves & $\begin{array}{l}\text { deeply } \\
\text { enclosed to } \\
\text { slightly below } \\
\text { rim }\end{array}$ & $\begin{array}{l}\text { rim level } \\
\text { or slightly } \\
\text { below rim }\end{array}$ & $\begin{array}{l}\text { deeply } \\
\text { enclosed }\end{array}$ & $\begin{array}{l}\text { slightly below } \\
\text { rim }\end{array}$ \\
\hline \multirow[t]{2}{*}{ Seeds } & $\begin{array}{l}\text { grey- } \\
\text { brown to } \\
\text { black }\end{array}$ & dark brown & $\begin{array}{l}\text { dark grey- } \\
\text { brown to } \\
\text { black }\end{array}$ & $\begin{array}{l}\text { dark brown } \\
\text { to black }\end{array}$ \\
\hline & narrow wing & slight wing & narrow wing & narrow wing \\
\hline
\end{tabular}


1. Eucalyptus incrassata Labill., Nov. Holl. Pl. Sp. 2: 12 (1806), tab. 150; non Sieber ex DC., Prodr. 3: 217 (1828), nom. illegit.

Type: south-western Australia, J.J.H. Labillardière s.n. (holo FI; iso BM, G, LINN, MEL). Cited as 'Habitat in terra Van-Leeuwin', and specimen annotated 'Nova Hollandia'.

The type of E. incrassata matches specimens of the taxon we are designating as E. incrassata sens. strict., which is intermediate in morphology between E. angulosa and E. captiosa (Fig. 1, and see Table 4). It occurs sporadically from the Stirling Ranges to east of Esperance along the south coast of Western Australia (Fig. 2), but appears to form distinct populations in a complex geographic mosaic with E. angulosa near the coast and E. captiosa further inland.

Mallee to $6 \mathrm{~m}$ tall. Bark smooth, grey to grey-brown, shedding in ribbons. Juvenile leaves disjunct, elliptical to ovate, to $8 \mathrm{~cm}$ long, $5 \mathrm{~cm}$ wide. Adult leaves disjunct; broad-lanceolate to elliptical, acuminate, glossy bright green, $5.0-11.0 \mathrm{~cm}$ long, $9-30 \mathrm{~mm}$ wide; petioles terete, $15-20 \mathrm{~mm}$ long; lateral veins at $35-45^{\circ}$ to midrib, moderately spaced, \pm degenerate; oil glands dense and distinct; intramarginal vein 1-3 $\mathrm{mm}$ from margin. Umbellasters axillary, 3-7-flowered; peduncles flattened, apically expanded, 10-28 mm long; pedicels terete to slightly quadrangular, 15-23 mm long. Mature buds ovoid, weakly to moderately costate, $12-16 \mathrm{~mm}$ long, $4-7 \mathrm{~mm}$ diam.; calyptra conical, often beaked, c. $1 / 2$ as long to as long as hypanthium. Fruits cup-shaped to cylindrical, weakly costate, 3-4-locular, 9-16 mm long, 7-12 mm diam.; calyptra scar and stemonophore flat, c. $0.5-1 \mathrm{~mm}$ wide; disc steeply depressed, $1.5-3 \mathrm{~mm}$ wide; valve tips raised to rim level. Seeds \pm pyramidal, deeply and regularly pitted, not winged, black, 1.0-2.0 mm long; hilum ventral; chaff red brown, smaller, angular (Fig. 1a, b)

Selected specimens (from 24 examined): Western Australia: c. $15 \mathrm{~km} \mathrm{~S}$ of Ravensthorpe on Hopetoun road and then $2 \mathrm{~km}$ along side road to Esperance, Blaxell 1701 \& Pryor, 23 June 1978 (NSW, PERTH); between Twilight Cove and Pink Lake, Esperance, Brooker 9516, 7 Nov 1986 (CANB, NSW); 200 m E of Lol Gray Picnic Site, Brooker 9893, 8 Mar 1988 (CANB, NSW); Along Southern Ocean West rd, west of Hopetoun, Carr 658 \& Carr, 2 Apr 1968 (CANB, AD, NSW, PERTH); Stirlings Range, Diels 2990, 31 May 1901 (B, NSW); Western Australia, Drummond 65, 1845 (BM, NSW); c. 2 km from Nunijup on Koonjie road, Hill 2451, Johnson \& Blaxell, 13 Nov 1986 (NSW, PERTH); 31.7 km from Old Ongerup Rd on Hamersley Drive, Hill 3145, 7 Sep 1988 (NSW); between Young [River] and Oldfield (halfway Esperance to Ravensthorpe), Johnson W 208, 18 Dec 1960 (NSW); 1 mile [1.6 km] N of Kundip, Johnson W 221, 19 Dec 1960 (NSW); Esperance, Maiden NSW 353217, Nov 1909 (NSW); 3.5-4 miles [5.6-6.4 km] N of Mt Bland, Fitzgerald River National Park, Tindale 3854a p.p., 30 Aug 1973 (NSW); between Albany and Williams River, Webb s.n., (MEL, NSW).

Intergrades: E. angulosa $\leftrightarrow$ E. incrassata

Selected specimens (from 2 examined): Western Australia: $14.2 \mathrm{~km} \mathrm{~S}$ of highway on track to Eyre telegraph station (now Eyre bird observatory), Hill 2171 \& Johnson, 3 Nov 1986 (NSW, CANB, MEL, PERTH).

2. Eucalyptus angulosa Schauer, in Walp., Repert. Bot. Syst. 2: 925 (1843).

Type: Western Australia: Swan River Colony, J. Drummond 4: 75 (lectotype BM, here designated; isolecto CGE, FI, K, PERTH, W). No type was cited in the protologue, and Schauer may have used collections by Brown, A. Cunningham, Labillardière or Drummond in drawing up the description. This typification clearly fixes the name to the coastal taxon generally understood to be represented by this name.

E E. cuspidata Turcz., Bull. Soc. Nat. Mosc. 22(2): 22 (1849). Also based on Drummond 4: 75.

E. angulosa was reduced to a variety of E. incrassata by Bentham (1867), which treatment was followed by Maiden (Crit. Revis. Eucalyptus 1903-1933, 1: 101). Blakely reverted to Schauer's treatment, then Burbidge (1947) followed Bentham with a narrower circumscription. Pryor and Johnson (1971) included E. angulosa in 


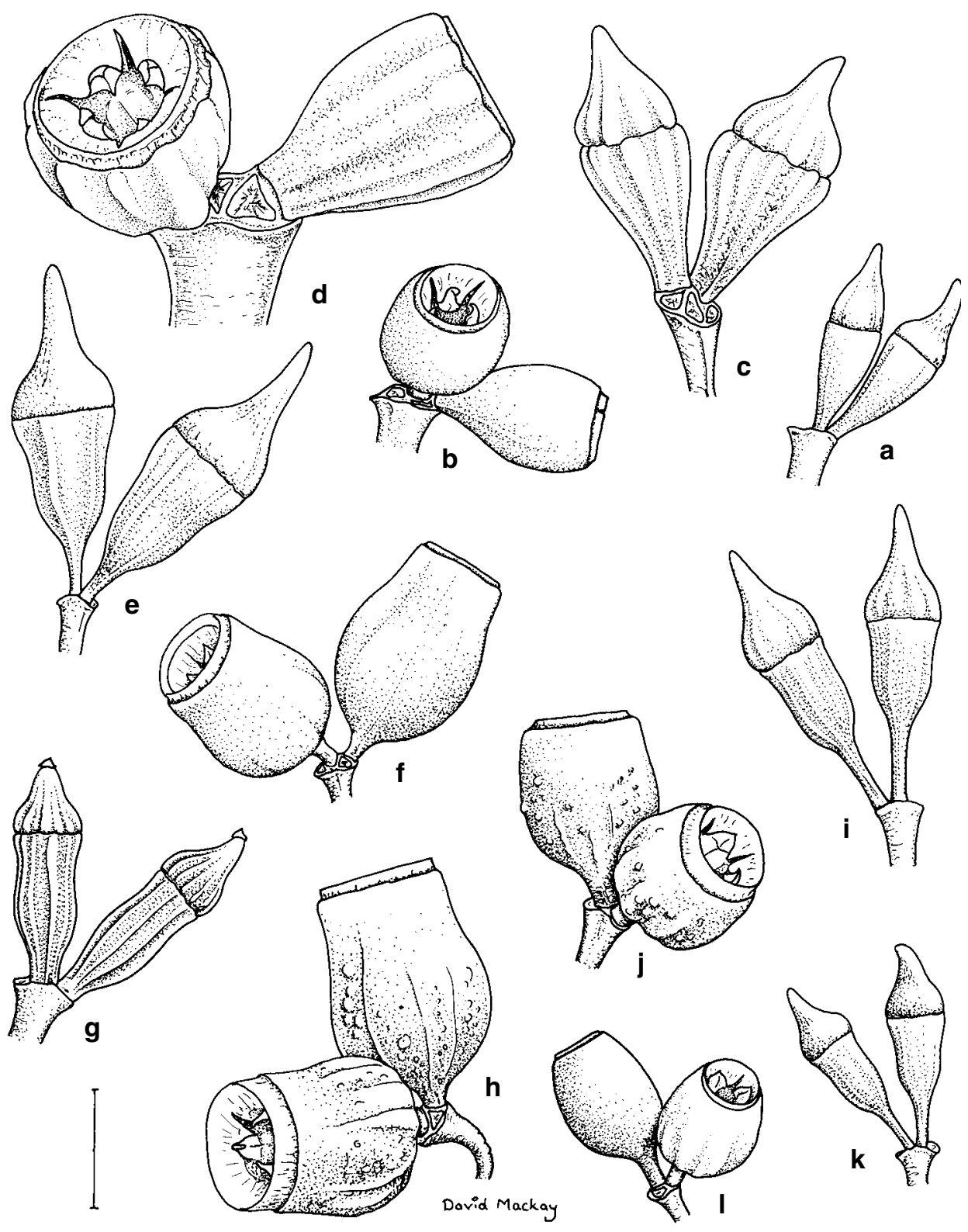

Fig. 1. E. incrassata. a, buds; b, fruits (from Maiden NSW 353217); E. angulosa. c, buds; d, fruits (from Brooker 8046). E. ceratocorys. e, buds. f, fruits (from Brooker 9088, Cometvale, W.A. Booker 9088, 13 Nov 1985 (PERTH, CANB, NSW). E. capitanea. g, buds. h, fruits (from Brooker 8466). E. costata subsp. costata. i, buds. j, fruits (from Carrick 3187). E. costata subsp. murrayana.k, buds. 1, fruits (from Gauba CANB 000253). Scale bar $=1 \mathrm{~cm}$. 
E. incrassata as a local variant of a highly variable species. Following more detailed studies, we now consider that a number of taxa can be distinguished within E. incrassata sens. lat., of which E. angulosa is one (Table 2). Chippendale (1988) applies essentially the same circumscription of E. angulosa in his treatment.

Mallee to $6 \mathrm{~m}$ tall. Bark smooth, grey to grey-brown, shedding in ribbons. Juvenile leaves disjunct, broad-elliptical, to $10 \mathrm{~cm}$ long, $7 \mathrm{~cm}$ wide. Adult leaves disjunct; broad-elliptical, apiculate, glossy bright green, $8.0-14.0 \mathrm{~cm}$ long, $25-50 \mathrm{~mm}$ wide; petioles terete, $15-30 \mathrm{~mm}$ long; lateral veins at $35-45^{\circ}$ to midrib, moderately spaced, \pm degenerate; oil glands dense and distinct; intramarginal vein $2-4 \mathrm{~mm}$ from margin. Umbellasters axillary, 3-7-flowered; peduncles flattened, broadly apically expanded, 10-20 mm long; pedicels terete to quadrangular, 3-5 mm long. Mature buds ovoid, coarsely distinctly costate, $11-17 \mathrm{~mm}$ long, $7-9 \mathrm{~mm}$ diam.; calyptra conical, usually not beaked, c. $1 / 2$ as long to as long as hypanthium. Fruits cup-shaped, distinctly broadly costate, 3-4-locular, 15-25 mm long, 15-25 mm diam.; calyptra scar and stemonophore flat, c. 1-2 mm wide; disc steeply depressed, $2-5 \mathrm{~mm}$ wide; valves enclosed. Seeds \pm pyramidal, deeply and regularly pitted, not winged, black, 2-3 $\mathrm{mm}$ long; hilum ventral; chaff red brown, smaller, angular (Fig. 1c, d).

E. angulosa is a coastal taxon, occurring in dense shrub thickets, usually on calcareous substrates, along the southern coast of Western Australia from West Cape Howe east past Israelite Bay, and in southern Eyre and Yorke Peninsulas and Kangaroo Island in South Australia (Fig. 2). It is distinguished within the series by the coarse leaves, buds and fruits (see also Table 4).

Selected specimens (from 69 examined): South Australia: Encounter Bay, Cleland 16, Feb 1921 (NSW); between Fishery Bay and Cape Wiles, Blaxell 2063 \& Johnson, 17 June 1983 (NSW, CANB); Stamford Hill, Maiden s.n., Jan 1907 (NSW); Port Lincoln to Coffins Bay, Maiden s.n., Jan 1907 (NSW); Mt Hope, Noble 7 E Bawden, Feb 1981 (NSW); 4 km S Mt Hope Post Office 85 km NW Port Lincoln, Pickard 2522, 10 Dec 1973 (NSW); Porter Bay, S of Port Lincoln, Erosion control area between Bay and Point, Symon 13712, 20 Dec 1983 (AD, CANB, NSW, US).

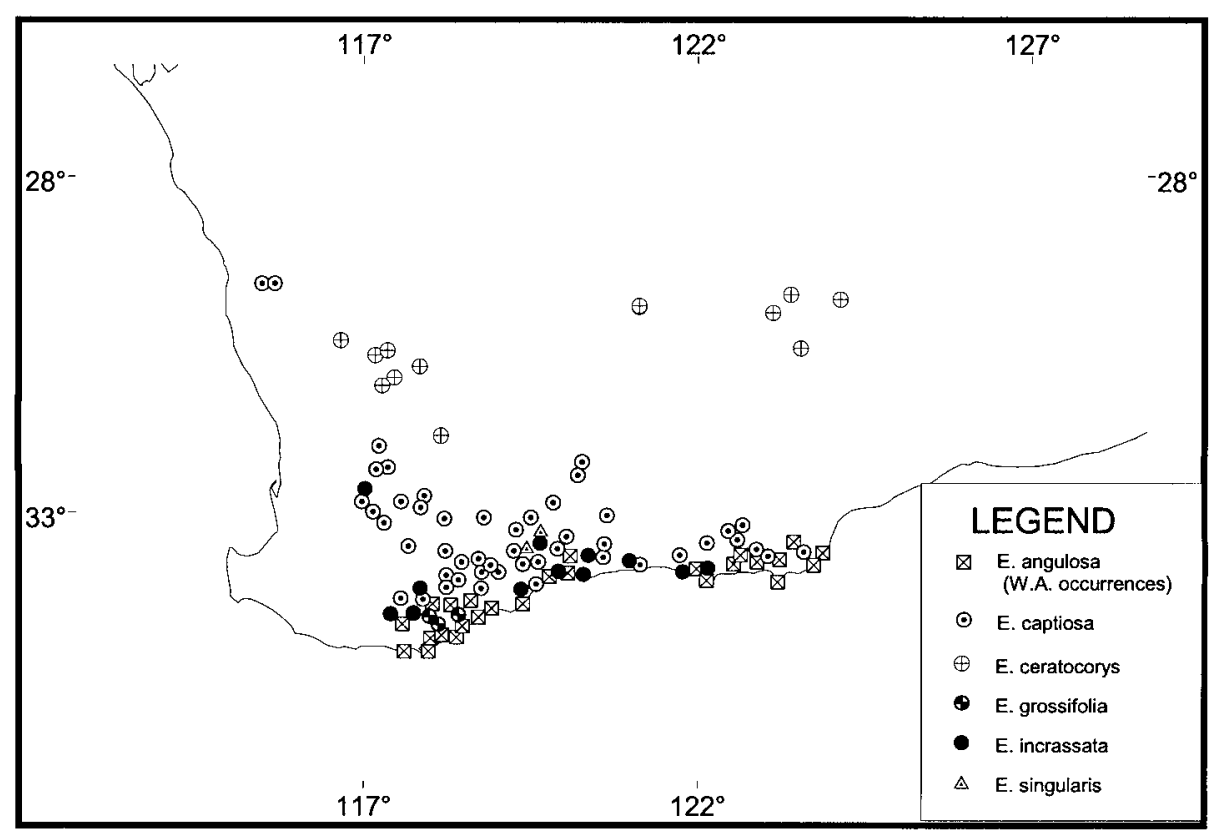

Fig. 2. Distribution of E. angulosa p.p., E. captiosa, E. ceratocorys, E. grossifolia, E. incrassata, E. singularis. 
Western Australia: N of Mt Le Grand, Cape le Grand National Park, Blaxell 1742, Pryor \& J. Briggs, 15 Sep 1978 (NSW, PERTH); 6 km south of Fisheries Road on Duke of Orleans Bay Road, Blaxell 86-077 \& Brooker, 6 Nov 1986 (NSW, CANB, PERTH); 22 km (direct) north of Wellstead, 2 km northwest of Rams Head on Monjebup road, B. Briggs 7877 \& Johnson, 11 Oct 1984 (NSW, CANB, PERTH); Cheyne Beach (east), Brooker 6686, 28 Dec 1979 (CANB, NSW, PERTH); Sandy Hook Island near Esperance, Brooker 7494, 1 May 1982 (CANB, NSW); Kojoneerup Springs road corner with Chillinup road, Brooker 8046, 23 Mar 1983 (CANB, NSW); Along Southern Ocean West road, W of Hopetoun, Carr 659 \& Carr, 2 Apr 1968 (CANB, BRI, CANB, MEL, NSW, PERTH); Bremer Bay, just out of town on Borden road, Carr 1129 \& Carr, 4 Sep 1969 (CANB, AD, BRI, CANB, MEL, NSW); Rotary Lookout, Esperance, Chippendale 183, 14 Mar 1967 (CANB, NSW); Warriup Rd, 15.2 km E of junction with Hassell Rd, c. 76 km (by road) NE of Albany, Conn 3363 \& Scott, 10 Oct 1989 (NSW); Stirling Range, junction of East Pillenorup and South Isongerup Tracks, Crisp 5277, 18 Jan 1979 (CBG, NSW, PERTH); Nova Hollandia, Drummond 75, (K, NSW); Culham Inlet W of Hopetoun, George 7596 \& Carr, 22 Feb 1966 (CANB, DNA, BRI, NSW, MEL, AD, PERTH, HO); Mt Ragged turnoff, $128.7 \mathrm{~km} \mathrm{~S}$ of Balladonia roadhouse on track to Israelite Bay, Hill $251 \mathcal{E}$ Johnson, 20 Oct 1983 (NSW, CANB); Mount Melville Garbage Tip (16.5 km from Highway), Hill 2430, Johnson \& Blaxell, 12 Nov 1986 (NSW, PERTH); West Cape Howe, Bruce Tarbottom memorial walk, on eastern slope of ridge, Hill 3078, 5 Sep 1988 (NSW, CANB, PERTH); Isthmus Hill trig. Flinders Peninsula, south of Albany, Powell 3216, Everett \& Bedford, 15 Nov 1985 (NSW, PERTH); Cape Riche, dunes above beach, Powell 3247, 16 Nov 1985 (NSW, PERTH, CANB); $8.4 \mathrm{~km} \mathrm{~W}$ of the ruins at Israelite Bay, Pryor $177 \mathcal{E}$ J. Briggs, 26 Oct 1978 (CANB, NSW); $131.8 \mathrm{~km} \mathrm{~S}$ of Balladonia (at turnoff to Israelite Bay), Pryor $186 \mathcal{E}$ J. Briggs, 26 Oct 1978 (CANB, NSW).

\section{Eucalyptus costata F. Muell., Trans. Victorian Inst.: 33 (1855).}

Type: South Australia: Angaston, Behr s.n., Dec 1848 (lecto MEL 1552443; here designated; isolecto K). Cited as: 'Behr \& Muell. Coll.'; 'In the Mallee scrub, from the Murray River to Spencer's Gulf.' This specimen was labelled E. incrassata var. angulosa by Mueller, but is the only specimen in MEL which can fit this citation.

Maiden (Crit. Revis. Eucalyptus 1903-1933, 1: 102) gave the authority for this name as R. Br., but Mueller did not acknowledge Brown or cite Brown's collection. Mueller did specifically cite Behr and Mueller as collectors, so the authority must remain as above, and Maiden's statement treated as below. The name has no connection with Metrosideros costata Gaertn. (三 Angophora costata (Gaertn.) Britten).

E. costata was included in E. incrassata var. angulosa by Bentham (1867) and Maiden (Crit. Revis. Eucalyptus 1903-1933, 1: 101), and in E. angulosa by Blakely (1934). Burbidge (1947) recognised it as a variety of E. incrassata, and Pryor \& Johnson (1971) included it in a broadly circumscribed E. incrassata. We now divide E. incrassata sens. lat. into several taxa, one of which is E. costata.

Mallee to $5 \mathrm{~m}$ tall. Bark smooth, grey to grey-brown, shedding in ribbons. Juvenile leaves disjunct, ovate to elliptical, to $10 \mathrm{~cm}$ long, $5 \mathrm{~cm}$ wide. Adult leaves disjunct; lanceolate to broad-lanceolate or narrow-elliptical, acuminate, glossy bright green, 6.0-11.0 cm long, 13-28 mm wide; petioles terete or slightly flattened, 12-20 mm long; lateral veins at $35-45^{\circ}$ to midrib, moderately spaced, \pm degenerate; oil glands dense and distinct; intramarginal vein 1-2 $\mathrm{mm}$ from margin. Umbellasters axillary, 3-7flowered; peduncles flattened, apically expanded, 12-18 $\mathrm{mm}$ long; pedicels terete, 3-10 mm long. Mature buds ovoid, weakly to moderately costate, $9-18 \mathrm{~mm}$ long, $5-8 \mathrm{~mm}$ diam.; calyptra conical, often beaked, c. $1 / 2$ as long to as long as hypanthium. Fruits ovoid or cup-shaped to cylindrical, weakly to moderately costate, 3-4-locular, 9-16 mm long, 7-12 mm diam.; calyptra scar and stemonophore flat, c. $0.5-1 \mathrm{~mm}$ wide; disc steeply depressed, 1.5-3 mm wide; valves deeply enclosed to just below rim level. Seeds \pm pyramidal, deeply and regularly pitted, narrowly winged, dark grey-brown to black, 1.0-1.5 mm long; hilum ventral; chaff red brown, smaller, angular (Fig. 1).

Distinguished within the series by the following: mallee; juvenile leaves medium to large (to $10 \times 5 \mathrm{~cm}$ ); adult leaves lanceolate to broad-lanceolate; calyptra short (1:b < 
2:1); fruits shallowly ribbed to almost smooth, urceolate, medium size (9-16 mm long, 7$21 \mathrm{~mm}$ diam., see also Table 4).

Two subspecies are recognised, as follows

\section{A. Eucalyptus costata F. Muell. subsp. costata}

Fruits ovoid to cup-shaped, large (11-16 mm long, 9-12 mm diam.), distinctly ribbed, valves deeply enclosed to slightly below rim level (Fig. 1i, j).

Restricted to South Australia, on red sand or sandy loam, central Eyre Peninsula, Yorke Peninsula and the upper and lower Murray Mallee regions, east almost to the Victorian border (Fig. 3).

Intergradation occurs in marginal regions with E. angulosa and hybrids are known with E. rugosa R. Br. ex Blakely.

Conservation status: not considered to be at risk.

Selected specimens (from 57 examined): South Australia: c. $10 \mathrm{~km} \mathrm{~N}$ of Cummins, Blaxell $2062 \mathcal{E}$ Johnson, 17 June 1983 (NSW, CANB); c. 16 km south of Curramulka, Blaylock 1801, 30 Apr 1973 (AD, NSW); Goolwa, c. 65 km south-south-east of Adelaide, River Murray Lakes, Boomsma, 9 Nov 1967 (AD, NSW); Padthaway, ca. $40 \mathrm{~km}$ SSW of Bordertown, Canty, 23 Oct 1980 (AD, NSW); Mt Weedind, about 15 miles [24 km] South from the Gawler Ranges and 125 miles [200 km] a little west of north from Port Lincoln, Gill, Dec 1912 (NSW); $74 \mathrm{~km}$ from Whyalla on Cowell road, Hill 2145 \& Johnson, 1 Nov 1986 (NSW, AD, CANB, MEL, PERTH); 7 km north of Arno Bay on Lincoln Highway, Hopton 21, 21 Oct 1988 (AD, NSW); c. $17 \mathrm{~km}$ S of Bordertown on Naracoorte road, Johnson 7920 \& Wilson, 20 Feb 1975 (NSW); 7 miles [11 km] south of Monarto South, McKern, 24 Aug 1958 (NSW); Murray Bridge, Maiden, Jan 1907 (NSW); 9 miles [14 km] from Port Broughton, towards Bute, Phillips, 11 Nov 1962 (CANB, NSW); 23 miles [36.8 km] from Bordertown, towards Keith, Phillips, 21 Oct 1966 (CANB, NSW); stock route $14 \mathrm{~km}$ SW Buckleboo HS [homestead], $150 \mathrm{~km}$ WNW Port Augusta, Pickard 2496, 9 Dec 1973 (NSW); between Bordertown and Keith, 8 miles (13 km) WNW of Bordertown, Smith 67/201, 17 Nov 1967 (MEL, NSW); area between Oak Dam (Frenchs Dam) and Gypsum Hills c. 32 miles [51 km] N of Overland Corner, Symon 3631, 9 Oct 1965 (AD,

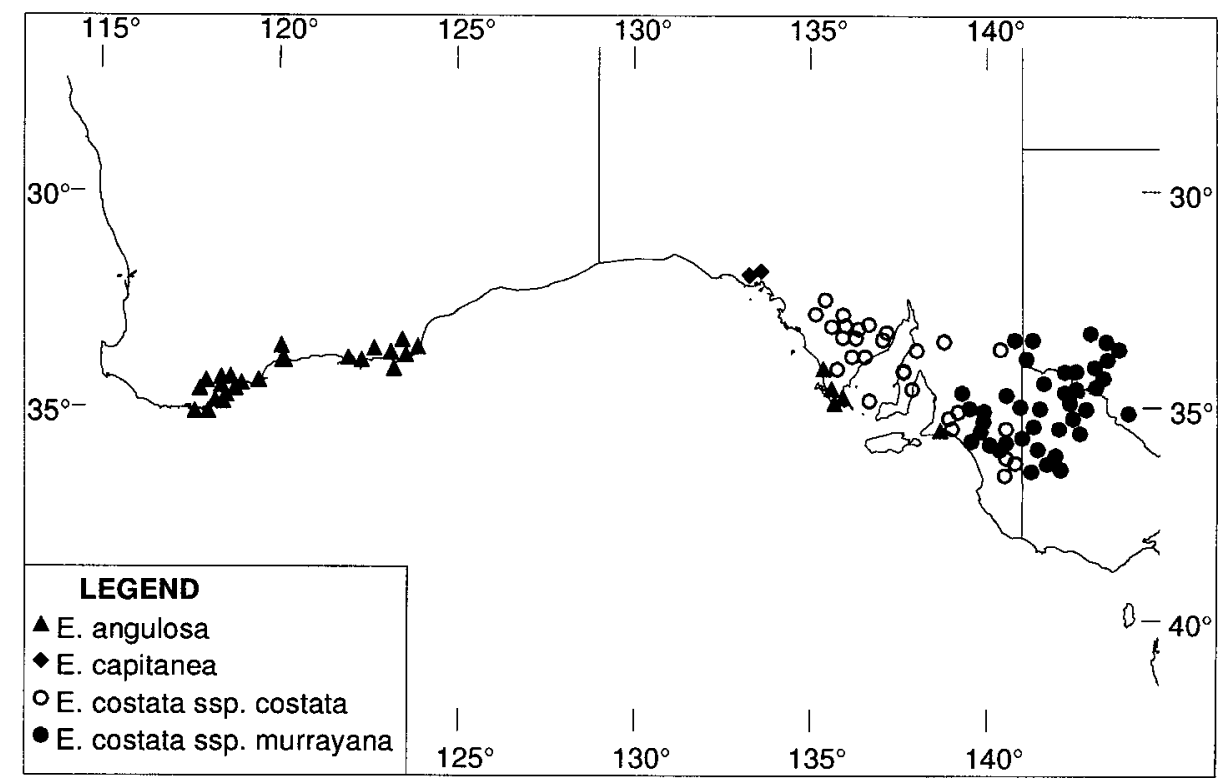

Fig. 3. Distribution of E. angulosa, E. capitanea, E. costata subsp. costata, E. costata subsp. murrayana. 
NSW); Hambidge Reserve, NW and NNW from Prominent Hill, Symon 4186, 8 Oct 1966 (AD, NSW); Hincks National Park, the inner NW angle of the reserve, $S$ of the Verran Hill road exit, Symon 6265, 9 Oct 1968 (AD, CANB, NSW); Gawler Ranges, $21 \mathrm{~km} \mathrm{SW}$ of Yardea on road to Minnipa, Symon 8106, 2 Oct 1972 (AD, MO, NSW); 8 miles [13 km] N of Arno Bay, Tindale 467, 12 Sep 1970 (NSW, AD, PERTH); 3 miles [4.8 km] south of Pine Point, Waterhouse 1374 a, 7 Feb 1970 (NSW); 7 miles [11 km] out of Moonta on Maitland Rd, Waterhouse 1384, 9 Feb 1970 (NSW).

Intergrades: E. angulosa $\leftrightarrow$ E. costata subsp. costata

Selected specimens (from 6 examined): South Australia: near Waitpinga, Brooker 6927, 9 May 1980 (CANB, AD, NSW); $2.5 \mathrm{~km}$ N of Waitpinga Beach towards Victor Harbour road, Chippendale 1342 $\mathcal{E}$ Brennan, 18 July 1975 (CANB, NSW); S from Sandergrove Siding towards Milang on abandoned railway line, between second \& third road crossings, Pearce 275, 22 Sep 1982 (AD, CANB, NSW); Newland Head to Waitpinga, Fleurieu Peninsula, Schodde 5185, 2 July 1967 (AD, NSW); 3 miles [4.8 km] E of Wanillo on North Shields Rd, Tindale 554, Sep 1970 (NSW, AD, K).

Hybrids: E. costata subsp. costata $\times$ E. rugosa

Specimens examined: South Australia: Eyre Peninsula, between Fishery Bay and Cape Wiles, Blaxell 2063 \& Johnson, 17 June 1983 (NSW).

3B. Eucalyptus costata F. Muell. subsp. murrayana L.A.S. Johnson E K.D. Hill, subsp. nov.

$\mathrm{Ab}$ E. costata subsp. costata distinguitur fructibus cylindricis relative minoribus $(9-13 \mathrm{~mm}$ longis, 7-10 mm diametro) et paene laevibus.

Type: Victoria: $42 \mathrm{~km}$ E of Ouyen on Manangatang road, J.D. Turner $125 \mathcal{E}$ H. Vos, 16 Sep 1977 (holo NSW; iso CANB, MEL, AD, PERTH).

Distinguished from subsp. costata by the cylindrical, small fruits (9-13 mm long, 7-10 mm diam.) that are almost smooth with valves at or slightly below rim level (Fig. 1k, 1, see also Table 4).

Scattered but locally frequent on red sandy loams and desert sands, from the Murray Mallee and 90-mile Desert of South Australia through Victoria almost to Swan Hill, and north to Pooncarie and Koraleigh in New South Wales (Fig. 3).

Extensive zones of intergradation occur between the two subspecies in the south-east of the range, from Dimboola and Mt Arapiles west to the Victorian border, and through the 90-mile Desert to the lower Murray in South Australia. A complete breakdown occurs in this area in South Australia, with a full range between the two end points evident.

Conservation status: not considered to be at risk.

The epithet is from the Murray region, where this taxon occurs.

Selected specimens (from 93 examined): New South Wales: S. Far W. Plains: 3 km Sth Prungle on Rd to Hwy, Cunningham 2477 \& Milthorpe, 24 July 1974 (NSW); 24 miles [38 km] from Pooncarie towards Darnick along Pooncarie to Darnick road, Dunlop 1465, 31 Aug 1969 (CANB, NSW); $2.5 \mathrm{~km}$ W of Bidura Homestead, Fox 7910015, 4 Oct 1979 (NSW); $12 \mathrm{~km}$ NE of Prungle Homestead, Fox 7910024, 5 Oct 1979 (NSW); 16 km east of Tarawi homestead, Fox 8304092 \& Fallding, 29 Apr 1983 (NSW); E. incrassata site just off Bicentennial Rd \& Belmore Rd, Fox 8411329, Nov 1984 (NSW); about 12 miles $[19 \mathrm{~km}] \mathrm{E}$ of Wampo towards Boree Plns (between Turlee and Hatfield), Johnson $\mathcal{E}$ Constable, 19 Mar 1959 (NSW); 12 miles [19 km] E of Turlee, ENE of Mildura Johnson B 2794 \& Briggs, 26 May 1969 (NSW); 18 miles [29 km] W of Euston, Mulham s.n., 22 Sep 1970 (NSW); near Tapalin mail-run turn-off on Sturt Highway, about 30 km east of Euston, Noble 1036, 5 May 1977 (NSW); Birdwood Station, Pooncarie, Noble 4, 11 Apr 1979 (NSW); Mylatchie via Balranald, Semple 1357, 25 May 1982 (NSW); 13 km NE Belmore homestead on Belmore to Belvedere Road, Turner $31 \mathcal{E}$ Vos, 5 Aug 1976 (CANB, NSW); 3 miles [4.8 km] E Gal Gal along track to Mandleman, Whaite 2051, 15 Nov 1956 (NSW); 11 km SW of Bellnar homestead on Arumpo to Buronga road, Wilson 3270, 4 Dec 1980 (NSW). 
SW. Plains: ca. $1.5 \mathrm{~km}$ SE of Hypurna homestead on main road, ca. $39 \mathrm{~km}$ by road N of Wentworth to Renmark road, Conn 1034, 14 Sep 1980 (AD, NSW); roadside ca. $2.5 \mathrm{~km}$ south of Cambrai, Jackson 3782, 6 Aug 1980 (AD, NSW); c. 3 miles [4.8 km] E of Koraleigh, on road to Lake Poomah (c. 1 mile [1.6 km] from Lake Poomah), Johnson s.n., 28 May 1969 (NSW 353325).

South Australia: Ki Ki, about 30 miles [48 km] SE of Tailem Bend, Banks B 1273, 4 June 1968 (CANB, NSW); Tintinarra [Tintinara], Cambage, 23 Mar 1901 (NSW); 90 Mile (Murray Desert), Gill s.n., Mar 1901 (NSW 353569); mallee heath 2 miles [3.2 km] E of Adelaide University Experimental Plot, Dark Island, about 10 miles [16 km] NE of Keith, Melville 462 \& Specht, 14 Aug 1952 (K, NSW); 5 km W of Murray Bridge, Nordenstam 1069 \& Anderberg, 7 Nov 1989 (NSW); Block 75 near old Telegraph Reserve, on oil search rd County Hamley, Symon 3808, 11 Oct 1965 (AD, HUJ, K, NSW); Belacre Simpson property, c. 24 km SE of Meningie, Symon 8553, 9 June 1973 (AD, CANB, NSW); 18 km N Pinaroo towards Paruna, Turner 18 \& Vos, 3 Aug 1976 (CANB, NSW); 13 km S Paruna turnoff to Pinaroo, Turner $106 \mathcal{E}$ Vos, 14 Sep 1977 (CANB, AD, MEL, NSW, PERTH); $10 \mathrm{~km}$ along road to Bow Hill from Mannum Road, Whibley 8717, 1 Nov 1983 (NSW, BRI, CANB, NSW).

Victoria: $3.3 \mathrm{~km}$ north-east of McCabes Hut ruin near Dimboola, Abell 531 \& Herscovitch, 17 Dec 1986 (NSW); Hattah Lakes National Park, between Hattah Station \& Hattah Lake, Beauglehole 19909, 11 Sep 1960 (MEL, NSW); Grampians, Mt Arapiles, SW side, Beauglehole 30886, 5 Sep 1969 (MEL, NSW); plain SW of Mt Arapiles, Brooker 5966, 23 Aug 1978 (CANB, MEL, NSW); $8.3 \mathrm{~km} \mathrm{~S}$ of Werrimul at abandoned channel, Brooker 10320, 11 Oct 1989 (CANB, AD, MEL, NSW); along Konardin Tank Road, $0.4 \mathrm{~km}$ from the junction of Mournpoul Road, Hattah National Park, D'Aubert 484, Hind \& Duggan, 23 Jan 1989 (NSW); near Mildura, Gauba s.n. (CANB 000253, NSW); $26 \mathrm{~km}$ S of Murrayville along the road-track to Nhill, N border of the Big Desert Wilderness, Greuter 20910, 22 Sep 1988 (NSW); $33.7 \mathrm{~km}$ northwest of Horsham on Dimboola road (eastern edge of Dimboola), Hill 1661, Johnson E Wilson, 8 Mar 1986 (NSW); 2.4 km east of Gerang Gerung on highway, Hill 1669, Johnson E Wilson, 8 Mar 1986 (NSW); Lawloit Range, on Western Highway, $18.0 \mathrm{~km}$ SW on Nhill, Jobson 3702, 27 Aug 1995 (MEL, AD, BRI, CANB, NSW); Little Desert National Park, on road to camping area, c. $16 \mathrm{~km}$ SE of Nhill, Lyne 601 \& Hadlow, 10 Nov 1991 (CANB, AD, MEL, NSW, PERTH); Hattah, $35 \mathrm{~m} \mathrm{~W}$ of high voltage power line in swale between 1st and 2nd tower $\mathrm{S}$ of Last Hope Track, Macfarlane 116, 21 Aug 1996 (MEL, AD, CANB, HO, NSW); Big Desert, Pengana Parish, 35 miles [56 km] NE by N of Kaniva, Melville 1097, Morris, Hicks \& Williams, 19 Sep 1952 (K, NSW); Sandhill c. $10.5 \mathrm{~km}$ from Sunset Tank along road to Cowangie (Grid B 3), Short 1281, 29 Sep 1981 (MEL, NSW); 42 km Ouyen to Manangatang, Turner 125 \& Vos, 16 Sep 1977 (CANB, AD, MEL, NSW, PERTH).

Intergrades: E. costata subsp. costata $\leftrightarrow$ E. costata subsp. murrayana

Selected specimens (from 11 examined): Victoria: Mt Arapiles, SW side, Beauglehole 30886, 5 Sep 1969 (MEL, NSW); plain SW of Mt Arapiles, Brooker 5966, 5967, 23 Aug 1978 (CANB, MEL, NSW); $2.4 \mathrm{~km}$ east of Gerang Gerung on highway, Hill 1669, Johnson $\mathcal{E}$ Wilson, 8 Mar 1986 (NSW); Little Desert Nat. Park, 6 miles [9.6 km] S of Kiata, Muir s.n., Mar 1970 (CANB, NSW 154289); Dimboola, Reader s.n., (MEL, NSW 353722).

\section{Eucalyptus capitanea L.A.S. Johnson E K.D. Hill, sp. nov.}

Inter species ex affinitate $E$. incrassatae combinatione characterum sequentium distinguitur: habitus multicaulis; calyptra brevis (longitudo: diameter $<2: 1$ ); fructus costati, urceolati, magni (15-20 mm longi, 12-14 mm diametro).

Type: South Australia: $8.4 \mathrm{~km}$ N of Koonibba towards Yumbarra Conservation Park, M.I.H. Brooker 8466, 9 Mar 1984 (holo NSW; iso CANB, PERTH, MEL, AD).

Mallee to $4 \mathrm{~m}$ tall. Bark smooth, grey to grey-brown, shedding in ribbons. Juvenile leaves not seen. Adult leaves disjunct; lanceolate to broad-lanceolate or narrowelliptical, acuminate, glossy bright green, $7.0-13.0 \mathrm{~cm}$ long, $14-45 \mathrm{~mm}$ wide; petioles flattened, 14-30 mm long; lateral veins at $35-45^{\circ}$ to midrib, moderately spaced, \pm degenerate; oil glands dense and distinct; intramarginal vein 1-2 $\mathrm{mm}$ from margin. Umbellasters axillary, 3-7-flowered; peduncles flattened, apically expanded, $18-27 \mathrm{~mm}$ long; pedicels terete, 2-6 mm long. Mature buds ovoid, distinctly costate, 9-22 mm long, 6-9 mm diam.; calyptra conical, shortly beaked, $1 / 2-2 / 3$ as long to as long as 
hypanthium. Fruits urceolate, distinctly costate, 3-4-locular, 15-22 mm long, 12-15 mm diam.; calyptra scar and stemonophore raised, 1-2 mm wide; disc steeply depressed, 3-4 mm wide; valves deeply enclosed. Seeds \pm pyramidal, deeply and regularly pitted, narrowly winged circumferentially and with ventral ridges, dark grey-brown to black, 3-4 mm long; hilum ventral; chaff red brown, smaller, angular. (Fig. 1g, h).

E. capitanea is distinguished within the E. incrassata complex by the following combination of characters: mallee; calyptra short $(1: b<2: 1)$; fruits ribbed, urceolate, large (15-22 mm long, 12-15 mm diam.). See also Table 4.

Locally frequent but at present known from one site only, on the crests of red desert dunes near Koonibba (Fig. 3). Associated taxa include E. yumbarrana Boomsma and Triodia, with E. oleosa subsp. repleta L.A.S. Johnson \& K.D. Hill and E. brachycalyx Blakely lower on dune slopes and on swales.

Conservation status: a species of restricted occurrence, although the extent is not known (2K).

The epithet is from the Latin capitaneus, head or chief, in reference to the larger size of this species in all parts in comparison to related taxa.

Specimens examined: South Australia: $8.4 \mathrm{~km} \mathrm{~N}$ of Koonibba towards Yumbarra Conservation Park, Brooker 8466, 9 Mar 1984 (CANB, NSW); c. 2 km NW of Koonibba Hill on access track to new wheatlands, c. $30 \mathrm{~km}$ E of Penong, Hill 714 E Blaxell, 15 Nov 1983 (NSW, AD, CANB, PERTH); $7.3 \mathrm{~km}$ $\mathrm{N}$ of highway to $\mathrm{N}$ of Charra turnoff (30 km E of Penong, $40 \mathrm{~km} \mathrm{~W}$ of Ceduna), Hill 2157 \& Johnson, 2 Nov 1986 (NSW, AD, CANB, MEL, PERTH).

5. Eucalyptus grossifolia L.A.S. Johnson $\mathcal{E}$ K.D. Hill, sp. nov.

E. angulosam plusminusve approximans sed habitu erecto, sparso, emergenti nec humile nec denso differt.

Type: Western Australia: $1.3 \mathrm{~km}$ from Kambellup on Woogenellup rd (34'S $\left.117^{\circ} 59^{\prime} \mathrm{E}\right)$, K.D. Hill 2444, L.A.S. Johnson E D.F. Blaxell, 12 Nov 1986 (holo NSW; iso PERTH).

Mallee to $6 \mathrm{~m}$ tall. Bark smooth, grey to grey-brown, shedding in ribbons. Juvenile leaves disjunct, ovate to elliptical, to $10 \mathrm{~cm}$ long, $5 \mathrm{~cm}$ wide. Adult leaves disjunct; lanceolate to broad-lanceolate or narrow-elliptical to ovate, acuminate, glossy bright green, 5.0-12.0 cm long, 20-50 mm wide; petioles flattened, 11-26 mm long; lateral veins at $35-45^{\circ}$ to midrib, moderately spaced, \pm degenerate; oil glands dense and distinct; intramarginal vein 1-2 $\mathrm{mm}$ from margin. Umbellasters axillary, 7-flowered; peduncles flattened, apically expanded, 12-18 $\mathrm{mm}$ long, to $10 \mathrm{~mm}$ wide apically; pedicels terete, $0-4 \mathrm{~mm}$ long. Mature buds ovoid, sessile or shortly pedicellate, distinctly irregularly costate, 9-17 mm long, 6-8 mm diam.; calyptra conical, often beaked, $1 / 3-1 / 2$ as long to as long as hypanthium. Fruits cup-shaped to obconical, distinctly irregularly costate, 3-4-locular, 10-20 mm long, 9-15 mm diam.; calyptra scar and stemonophore flat, c. $1 \mathrm{~mm}$ wide; disc steeply depressed, 2-4 mm wide; valves enclosed. Seeds \pm pyramidal to patelliform, deeply and regularly pitted, narrowly winged circumferentially and with ventral ridges, dark grey-brown to black, $2-3 \mathrm{~mm}$ long; hilum ventral; chaff brown, smaller, angular (Fig. 4).

E. grossifolia is most similar to E. angulosa, differing mainly in the slender, sparse, erect, emergent habit in contrast to the low, dense, bushy habit of the latter (see also Table 4). $E$. angulosa is also largely restricted to calcareous sand deposits on or near the coast, whereas E. grossifolia occurs on lateritic residuals, often with a shallow siliceous sand mantle, some distance from the coast.

A component of rich mixed mallee shrublands, associated species including E. uncinata Turcz., E. falcata Turcz., E. pleurocarpa Schauer, E. pachyloma Benth., E. tetraptera Turcz. 
and E. preissiana Schauer. Known occurrences are mainly on white siliceous sand over laterite, apparently restricted to the Kalgan Plain region (Fig. 2).

Conservation status: known from a few small stands, all of which have been partly or substantially cleared (2V).

The epithet is from the latin grossus, thick, coarse, and folium, leaf, in reference to the thick, coarse foliage.

Selected specimens (from 8 examined): Western Australia: $1.3 \mathrm{~km}$ from Kambellup on Woogenellup road, Hill 2444, Johnson \& Blaxell, 12 Nov 1986 (NSW, PERTH); $0.8 \mathrm{~km}$ south of Johnson Road on Palmdale Road, Hill 3090, 5 Sep 1988 (NSW); 4.5 km from Chester Pass Road on Tackalarup Road, Hill 3091, 5 Sep 1988 (NSW); 12.6 km W of Chester Pass Rd on Woogenellup N Rd, Hill 3094, 6 Sep 1988 (NSW); 35.2 km from Chester Pass Rd on Chillinup Rd, Hill 3101, 6 Sep 1988 (NSW); 12 miles [19 km] from Porongorup on road to Borden, Hindmarsh s.n. \& Waterhouse, 11 Aug 1973 (UNSW 2525, NSW).

\section{Eucalyptus singularis L.A.S. Johnson E D.F. Blaxell, sp. nov.}

$\mathrm{Ab}$ E. incrassata et speciebus cognatis habitu non fruticoso ('mallee'), canopeo angusto et habitatione differt.

Type: Western Australia: Fitzgerald Road. $4.9 \mathrm{~km} \mathrm{SW}$ of the junction with Koornong Road, at 'Urara' property rd, c. $42 \mathrm{~km}$ WNW of Ravensthorpe (3332'S 119³7'E), B.G. Briggs 7828 E L.A.S. Johnson, 10 Oct 1984 (holo NSW; iso AD, CANB, PERTH).

Slender tree ('mallet') to $6 \mathrm{~m}$ tall. Bark smooth, grey, shedding in ribbons. Juvenile leaves disjunct, ovate to elliptical, to $8 \mathrm{~cm}$ long, $2.5 \mathrm{~cm}$ wide. Adult leaves disjunct; narrow-lanceolate to lanceolate, with a curved, acuminate and prominent tip, glossy dark green, 7.0-13.0 cm long, 8-20 mm wide; petioles terete, 10-20 mm long; lateral veins at $30-45^{\circ}$ to midrib, irregularly spaced; oil glands not distinct; intramarginal vein

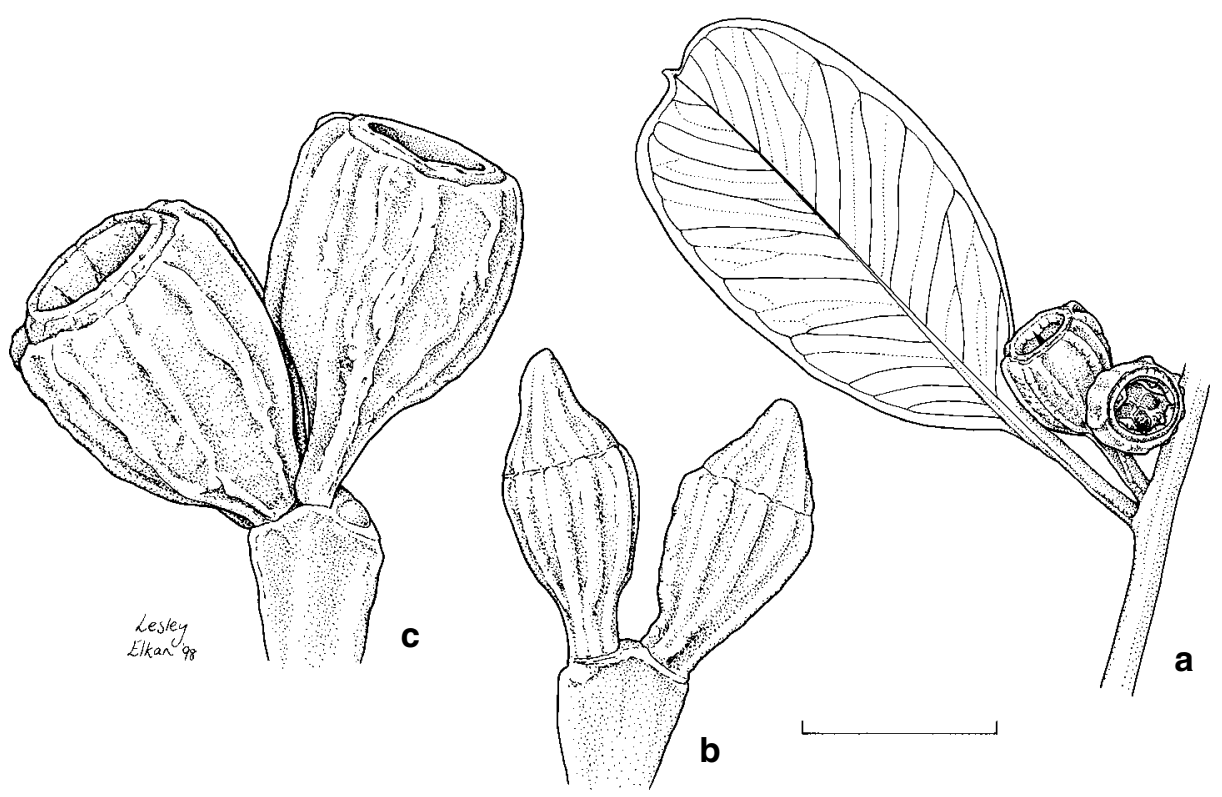

Fig. 4. E. grossifolia. a, adult leaves, inflorescence and fruits; $\mathbf{b}$, inflorescence and buds; c, inflorescence and fruits. (from Hill 3101). Scale bar $=1 \mathrm{~cm}$. 
c. $1 \mathrm{~mm}$ from margin. Umbellasters axillary, 7-flowered; peduncles flattened, apically expanded, decurved, 12-30 $\mathrm{mm}$ long, to $10 \mathrm{~mm}$ wide apically; pedicels vaguely quadrangular, ridged, to $8 \mathrm{~mm}$ long. Mature buds ovoid, distinctly costate, $15-20 \mathrm{~mm}$ long, 5-8 mm diam.; calyptra conical, long-beaked, 1.5-2 times as long as hypanthium. Fruits cup-shaped to cylindrical, distinctly costate, 3-locular, 15-20 mm long, 8-10 mm diam.; calyptra scar and stemonophore slightly raised, $1 \mathrm{~mm}$ wide; disc level with rim; valves just below rim. Seeds \pm pyramidal, distinctly pitted, very narrowly winged circumferentially and with ventral ridges, dark grey-brown to black, 2-3 mm long; hilum ventral; chaff red-brown, angular (Fig. 5).

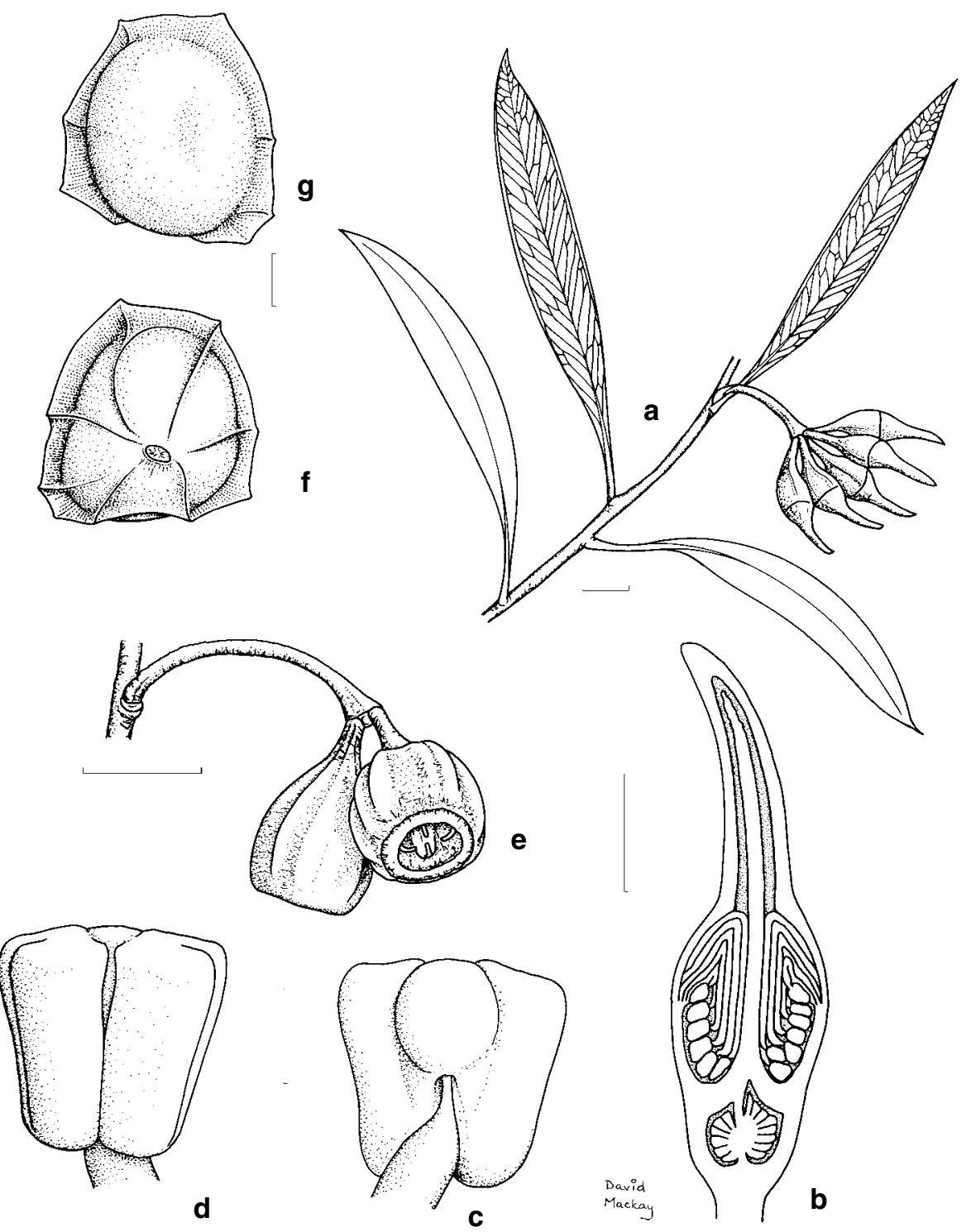

Fig. 5. E. singularis. a, adult leaves, inflorescences and buds; $\mathbf{b}$, longitudinal section of bud. c, $\mathbf{d}$, anther; e, inflorescence and fruits; $\mathbf{f}, \mathbf{g}$, seed (from B. Briggs 7828 ). Scale bars: $a, e=1 \mathrm{~cm}$; $\mathrm{b}=5 \mathrm{~mm} ; \mathrm{c}, \mathrm{d}, \mathrm{f}, \mathrm{g}=0.5 \mathrm{~mm}$. 
E. singularis is distinguished within the E. incrassata complex by its habit, a nonlignotuberous tree of 'mallet' form; its narrow crown and its substrate, shallow sand on lateritic rises (see also Table 4).

Only known from two (or three) populations in the region WNW of Ravensthorpe (Fig. 2). Associated species is predominently E. argyphea L.A.S. Johnson \& K.D. Hill, but, at one locality, E. phaenophylla Brooker \& Hopper and E. dissimulata Brooker are present.

Conservation status: a species of very restricted distribution, although further searching may increase its range. Probably at risk because of its occurrence along road verges in farming land $(2 \mathrm{~K})$.

The epithet is from the Latin singularis, alone, solitary, in reference to the habit of this species in contrast to all other members of the E. incrassata complex.

Specimens examined: Western Australia: $4.8 \mathrm{~km}$ from Koornong Road on Fitzgerald Road, Brooker 8809, 18 Jan 1985 (CANB, NSW, PERTH); Mallee Road, south of Lake King, Brooker 8888, 13 Mar 1985 (CANB, NSW, PERTH); Old Ravensthorpe Road, Brooker 10146, 12 Dec 1988 (CANB, NSW, PERTH); $4.5 \mathrm{~km}$ from Millsteed Road on Mallee Tree Road, Hill 2396, Johnson, Blaxell \& Brooker, 9 Nov 1986 (NSW, CANB, MEL, PERTH).

\section{Series Torquatae}

Series distinguished as follows: seeds ovoid-angular, wingless, dull, dark brown, grey or black, with regular deep sharp-edged pits; hilum indistinct; umbellasters 3 -11-flowered; filaments \pm slender, basally \pm constricted, apically gradually tapered to connective.

The first taxa described in this series as now circumscribed were E. corrugata Luehm. and E. torquata Luehm. (Luehmann 1897), although Robert Brown had earlier delineated two other taxa as E. anceps and E. rugosa in manuscript (both names were later adopted by Blakely (1934) for the taxa more or less as Brown delineated them). These were followed by E. griffithsii Maiden (1911). Maiden had earlier confused many different taxa including E. anceps (R. Br. ex Maiden) Blakely and E. rugosa in a complicated and flawed attempt to circumscribe E. dumosa (Crit. Revis. Eucalyptus 1: 101), an impossible task in those times of no or little information on many of the taxa.

The additional taxa in this group were described by Maiden (E. melanoxylon Maiden, Crit. Revis. Eucalyptus 1922, 6: 351, E. concinna Maiden \& Blakely, Crit. Revis. Eucalyptus 1929, 8: 49) and then Blakely (E. brachycalyx Blakely (1934: 119), E. rugosa R. Br. ex Blakely (1934: 120).

Recognition and circumscription of this series has occurred only in recent years. Maiden placed some of the species known in section Macrantherae subsection Tereticornes on the basis of anther morphology, in different series based on bark characters and together with quite unrelated taxa. Blakely placed the different species then known (except E. melanoxylon Maiden) in section Macrantherae subsection Subtruncatae series Dumosae, primarily on the basis of the more or less costate fruits, but in several subseries and in each case together with other species now placed in different series. E. melanoxylon was wrongly removed by him to series Exsertae with a group of Red Gums.

Pryor and Johnson (1971) recognised a series Torquatae, including the then known species of the series as now treated, but also including a number of other related taxa. The related taxa were removed to series Merrickiae and Ovulares by Brooker (1979, 1981), to leave section Torquatae as discussed here (Table 5). The group was formally described as series Torquatae by Chippendale (1988), although he included E. deflexa Brooker, which was not included in a subsequent discussion of this series by Brooker 
and Hopper (1993), and which we also would now regard as quite distinct and belonging in a separate series (see Table 1). Brooker (2000) separated E. torquata into a separate series on the basis of autapomorphic novelties, ignoring informative grouping characters that clearly place it with the taxa here included in the series.

The following account and classification conclude our revisionary studies of this series, except that glaucous forms of E. concinna Maiden \& Blakely occurring sporadically between Mulline and Mussons Soak require further field investigation.

A noteworthy circular pattern of intergradation around the Nullarbor Plain is evident in this group, starting with E. melanoxylon in the southern Goldfields of Western Australia intergrading with E. pleurocorys, running east into E. brachycalyx to the south and south-east of the Nullarbor Plain to Eyre Peninsula, then into E. concinna in the northern Eyre Peninsula and north-west through the Great Victoria Desert, then into E. planipes west of the Nullarbor and into E. griffithsii Maiden in the Western Australian Goldfields.

Table 5. A classification of Series Torquatae

Series Torquatae

Subseries Laevosae
E. laevis
Subseries Corrugatosae
E. melanoxylon
E. brachycalyx
E. rugosa
E. pleurocorys
E. concinna
E. trachybasis
E. planipes
E. griffithsii
E. corrugata

Subseries Torquatosae

E. torquata

\section{Eucalyptus laevis L.A.S. Johnson E K.D. Hill, sp. nov.}

E. melanoxylon affinis sed fructibus laevibus ovoideisque et calyptra breviore obtusaque distinguitur.

Type: Western Australia: $3.3 \mathrm{~km} \mathrm{~W}$. of highway on track turning off $11 \mathrm{~km} \mathrm{~N}$. of Norseman (32 ${ }^{\circ} 09^{\prime}$ S, $\left.121^{\circ} 39^{\prime} \mathrm{E}\right)$, K.D. Hill 587, L.A.S. Johnson, D.F. Blaxell, M.I.H. Brooker $\mathcal{E}$ S.D. Hopper, 6 Nov 1983 (holo NSW; iso CANB, PERTH).

[E. species W, Brooker \& Kleinig 1990: 343 (1990)]

Tree to $15 \mathrm{~m}$ tall, sometimes mallee. Bark persistent on trunk and base of larger branches, grey, shortly fibrous-flaky; smooth, grey, shedding in ribbons above. Juvenile leaves not known.Adult leaves disjunct; narrow-lanceolate, acuminate, glossy bright green, $6.0-14.0 \mathrm{~cm}$ long, 8-15 mm wide; petioles terete or slightly flattened, 7-10 mm long; lateral veins at $30-45^{\circ}$ to midrib, moderately spaced, \pm degenerate; oil glands dense and distinct; intramarginal vein $0.5-1.5 \mathrm{~mm}$ from margin, \pm degenerate. Umbellasters axillary, 7-11 flowered; peduncles terete, 9-17 $\mathrm{mm}$ long; pedicels terete, 3-5 mm long. Mature buds ovoid, 6-7 mm long, c. $4 \mathrm{~mm}$ diam.; calyptra conical, 
strongly convex, obtuse, faintly ribbed, c. $1 / 2$ as hypanthium. Fruits ovoid, apically \pm truncate, constricted, 3-4-locular, 6-7 mm long, 5-6 mm diam.; calyptra scar and stemonophore flat, c. $0.5 \mathrm{~mm}$ wide; disc vertically depressed, $1.0-1.5 \mathrm{~mm}$ wide; valves deeply enclosed, vertically raised, ultimate tips rim-level or slightly exserted. Seeds \pm rounded, deeply and regularly pitted, dark grey-brown, 1.0-1.5 mm long; hilum ventral; chaff red brown, smaller, angular (Fig. 6).

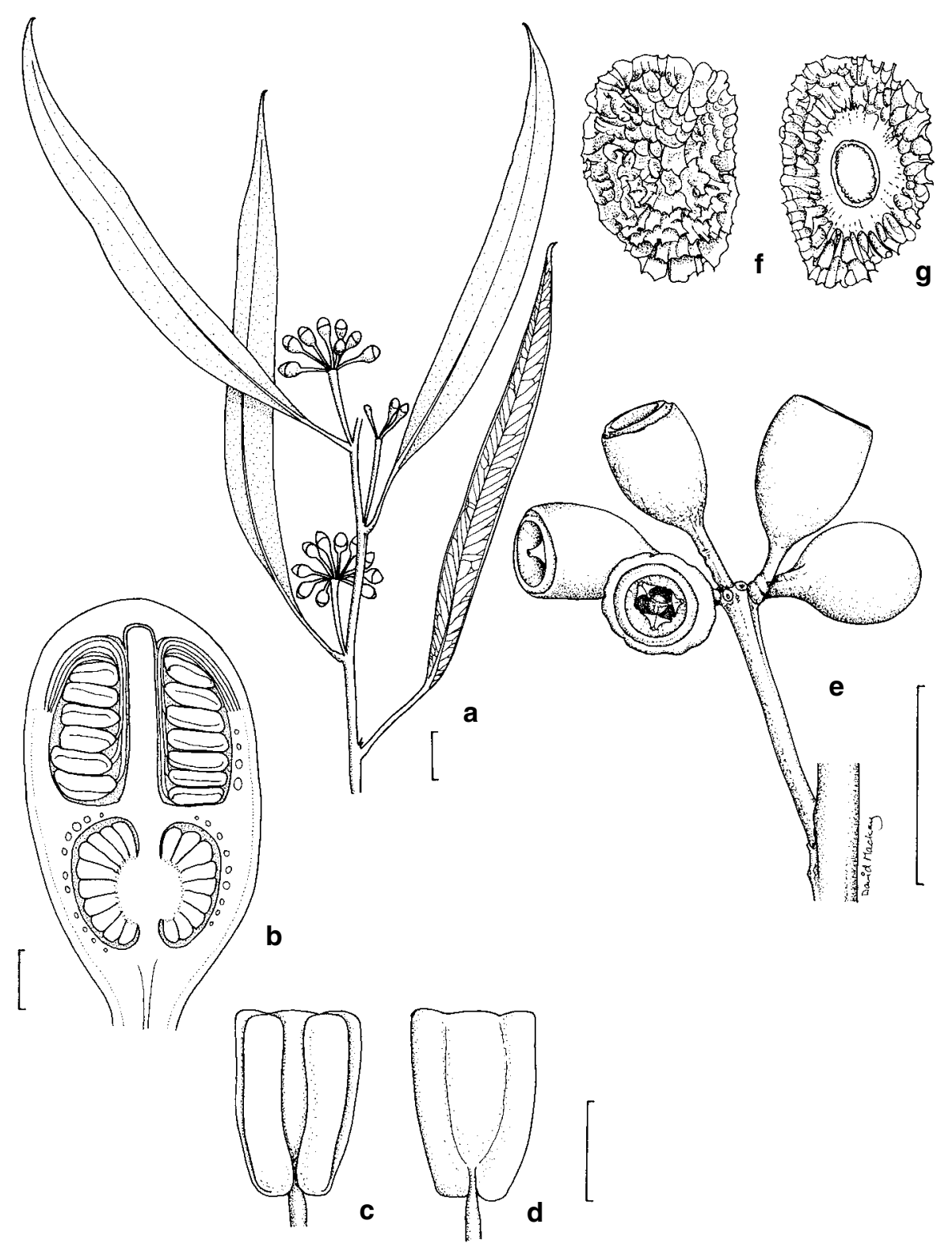

Fig. 6. E. laevis. a, adult leaves, inflorescences and buds; $\mathbf{b}$, longitudinal section of bud; $\mathbf{c}$, $\mathbf{d}$, anther; e, inflorescence and fruits; $\mathbf{f}, \mathbf{g}$, seed (from Hill 587). Scale bars: $\mathrm{a}, \mathrm{e}=1 \mathrm{~cm} ; \mathrm{b}, \mathrm{f}, \mathrm{g}=1 \mathrm{~mm} ; \mathrm{c}, \mathrm{d}=0.5 \mathrm{~mm}$. 
E. laevis is distinguished from E. melanoxylon by the smooth, ovoid to cylindrical fruits with less or non-exserted valves, and the shorter, obtuse calyptra.

A medium to large woodland tree of 'morrel' habit, occurring on heavy calcareous loams in more or less flat country, often associated with E. flocktoniae (Maiden) Maiden, E. lesouefii Maiden and a range of other woodland species. Widespread and relatively abundant between Norseman and Balladonia (Fig. 7).

Conservation status: not considered to be at risk.

The specific epithet is from laevis, a variant, commonly used in botanical Latin, of the classical levis, 'smooth'. It refers to the smooth calyptra.

Selected specimens (from 15 examined): Western Australia: 33.6 miles [ $54 \mathrm{~km}$ ] west of Balladonia towards Norseman, Brooker 2481, 14 Feb 1970 (PERTH, NSW); $3.3 \mathrm{~km} \mathrm{~W}$ of Coolgardie to Norseman road, Brooker 8347, 6 Nov 1983 (CANB, NSW); 0.5 miles [0.8 km] SW of Pioneer, Chippendale 148, 11 Mar 1967 (CANB, NSW); 67.2 miles [110 km] E of Norseman, Chippendale 159, 12 Mar 1967 (CANB, NSW); Fraser Range, $84 \mathrm{~km} \mathrm{~W}$ of Balladonia roadhouse on Highway 1, Hill 231 \& Johnson, 19 Oct 1983 (NSW, CANB, PERTH); $3.3 \mathrm{~km}$ west of Highway on track turning off $11 \mathrm{~km}$ north of Norseman, Hill 587, Johnson, Blaxell, Brooker \& Hopper, 6 Nov 1983 (NSW, CANB, PERTH); 24.6 km E of Norseman on highway, Hill 677 \& Blaxell, 14 Nov 1983 (NSW, CANB, PERTH); $10.6 \mathrm{~km}$ W of Balladonia roadhouse on highway, Hill 2182 \& Johnson, 4 Nov 1986 (NSW, CANB, MEL, PERTH); $124.3 \mathrm{~km} \mathrm{~W}$ of Balladonia roadhouse on highway, Hill 2833, 24 Aug 1988 (NSW); on Highway 1, $53 \mathrm{~km} \mathrm{~W}$ of Balladonia Roadhouse, Whaite 4042 E Whaite, 7 Sep 1976 (NSW).

8. Eucalyptus pleurocorys L.A.S. Johnson $\mathcal{E}$ K.D. Hill, sp. nov.

E. melanoxylon affinis sed calyptra latiore costataque, fructibus longioribus conicisque et regione basali quasi fibrosa cortice minus extensiva distinguitur.

Type: Western Australia: Junana Rock, $121 \mathrm{~km} \mathrm{~S}$ of Balladonia roadhouse on track to Mt Ragged (3323'S, 12324'E), K.D. Hill 240 E L.A.S. Johnson, 20 Oct 1983 (holo NSW; iso CANB, PERTH).

Mallee to $5 \mathrm{~m}$ tall, sometimes tree to $10 \mathrm{~m}$ tall. Bark persistent, grey, fibrous-flaky at base (to $3 \mathrm{~m}$ ); smooth, grey above. Adult leaves disjunct, lanceolate, often falcate, glossy bright green, acute or acuminate, $5.0-12.0 \mathrm{~cm}$ long, $0.8-2.0 \mathrm{~cm}$ wide. Petioles \pm flattened, $0.9-1.7 \mathrm{~cm}$ long; young stems angular. Lateral veins at c. $45^{\circ}$ to midrib,

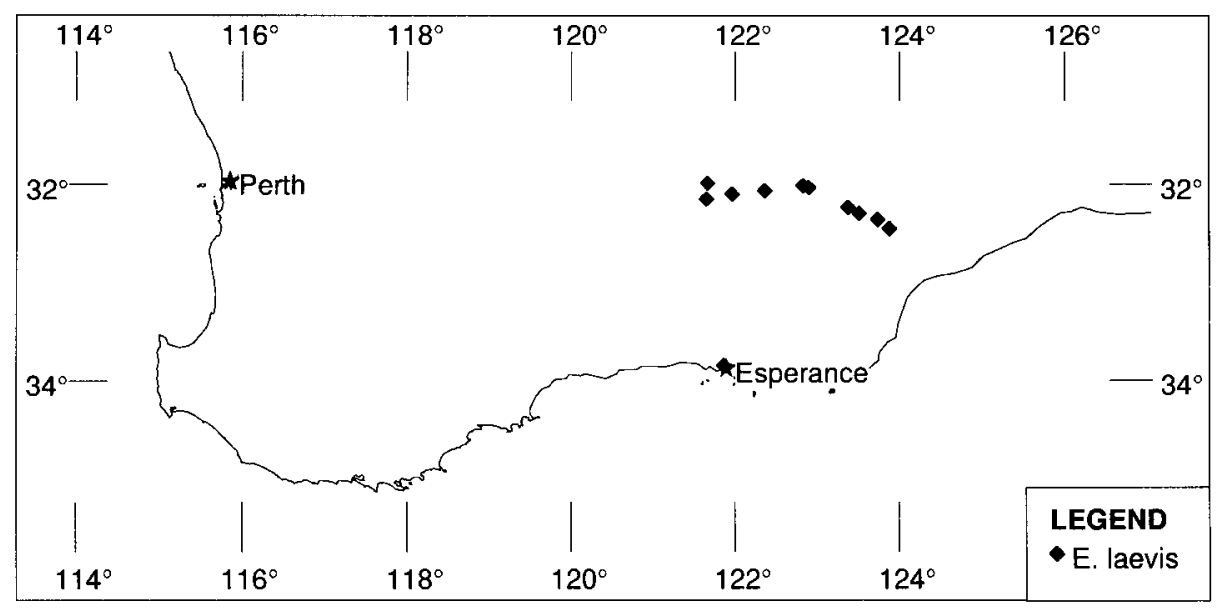

Fig. 7. Distribution of E. laevis. 
moderately spaced, somewhat obscure and irregular; intramarginal vein $0.5-1.0 \mathrm{~mm}$ from margin, present but obscure. Umbellasters axillary, 7-11-flowered. Peduncles \pm flattened 9-17 mm long. Pedicels \pm ribbed, 3-6 mm long. Mature buds ovoid, $8-10 \mathrm{~mm}$ long, 4-5 mm diam.; calyptra \pm cup shaped, obtuse, faintly ribbed, slightly shorter than hypanthium, distinctly narrower than hypanthium. Fruits obconical, tapered into pedicel, slightly constricted apically, 3-4-locular, 5-7 mm long, 6-8 mm diam.; calyptra scar and stemonophore flat or slightly raised, $0.5-1.0 \mathrm{~mm}$ wide; disc depressed at c. $45^{\circ}, 0.5-1.0 \mathrm{~mm}$ wide; valves narrowly triangular, acuminate, basally enclosed, apically ultimately vertically exserted, often broken at disc level. Seeds \pm angular, convex, deeply and regularly pitted, \pm fringed, dark grey-brown, 1.5-2.0 mm long; hilum ventral; chaff lustrous red-brown, smaller, angular (Fig. 8).

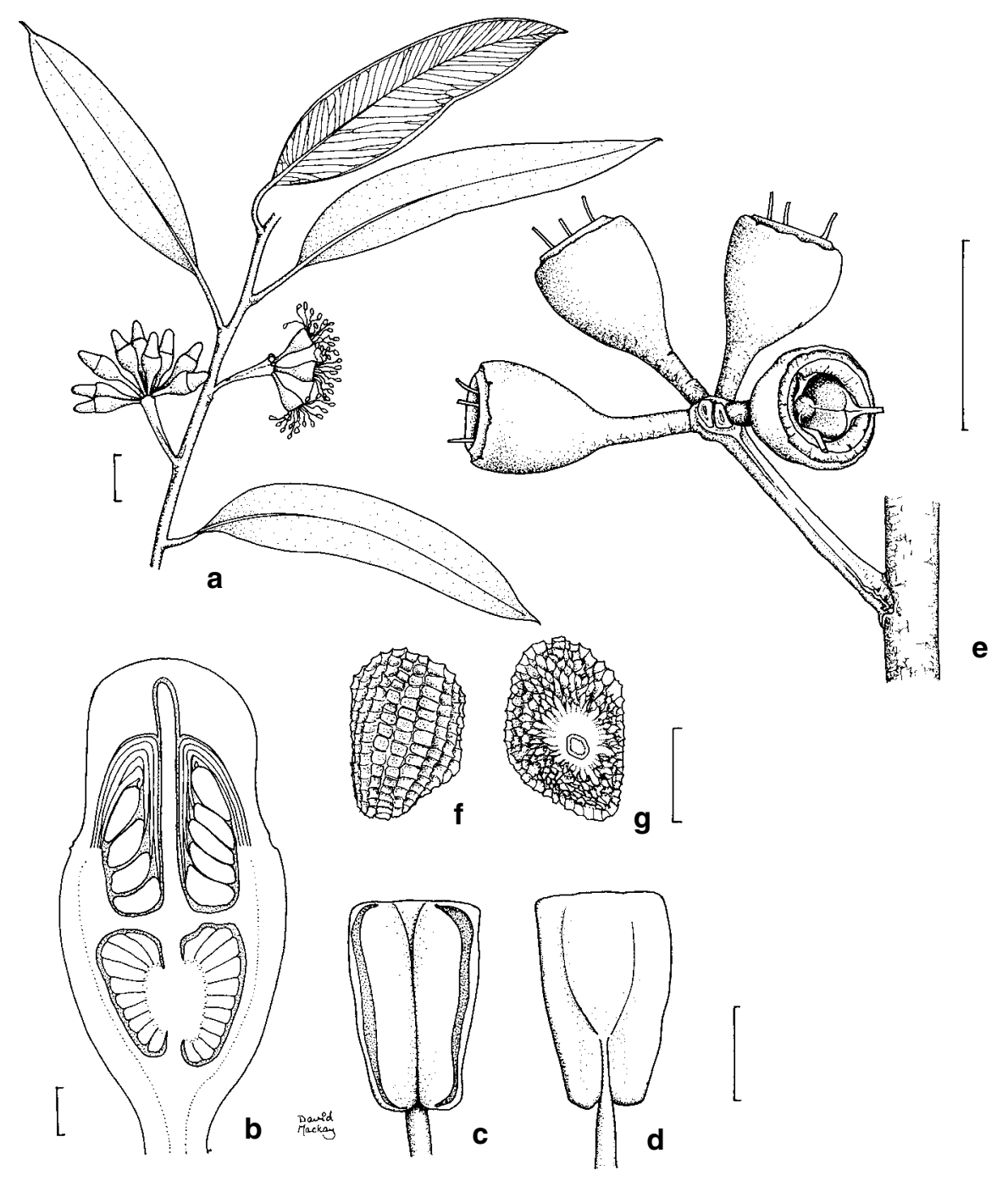

Fig. 8. E. pleucrocorys. $\mathbf{a}$, adult leaves, inflorescences, buds and flowers; $\mathbf{b}$, longitudinal section of bud; c, d, anther; e, infloresences and fruits; $\mathbf{f}, \mathbf{g}$, seed (from Hill 240). Scale bars: a, e $=1 \mathrm{~cm}$; $\mathrm{b}, \mathrm{f}, \mathrm{g}=1 \mathrm{~mm} ; \mathrm{c}, \mathrm{d}=0.5 \mathrm{~mm}$. 
E. pleurocorys is distinguished from E. melanoxylon by the broader, ribbed calyptra, the longer, conical fruits and the less extensive rough bark (see also Table 6).

This species occurs in a wide range of habitats, from mallee scrub on heavy calcareous soil over limestone to woodland on calcareous loam, and mallee heath on skeletal white sandy soil over quartzite. Associated species include E. gracilis F. Muell., E. oleosa F. Muell. ex Miq., E. flocktoniae and E. cooperiana F. Muell..

E. pleurocorys is recorded from near Mt Ragged and near Caiguna (Fig. 9). The intervening country is poorly explored and it is likely to occur throughout the region.

This taxon has in the past been included in E. rugosa, but its affinities are more with E. melanoxylon. E. rugosa, as here circumscribed, does not extend into Western Australia.

Conservation status: not considered to be at risk.

The epithet is from the Greek pleuron, 'a rib', and corys, 'helmet', referring to the ribbed calyptra.

Selected specimens (from 30 examined): Western Australia: 21.1 miles [34 km] south of Mt Ragged on track to Israelite Bay, Allan 756, 16 Sep 1971 (PERTH, NSW); $130 \mathrm{~km} \mathrm{~S}$ of Balladonia, SW of Mt Ragged, Brooker 5637, 3 Apr 1977 (CANB, AD, MEL, NSW, PERTH); 1.5 km from Israelite Bay track to Mt Ragged track, Brooker 8913, 8 Apr 1985 (CANB, NSW); $20.1 \mathrm{~km}$ from Israelite Bay track on Mt Ragged track, Brooker 8918, 8 Apr 1985 (CANB, NSW); c. 3 km S of Bandalup Hill, Brooker 9481, 11 Apr 1985 (CANB, NSW); c. 0.2 km E of Lake King turnoff on Ravensthorpe to Albany road, Brooker 9643, 19 May 1987 (CANB, NSW); Junana Rock, 121 km S of Balladonia roadhouse on track to Mt Ragged, Hill 244 E Johnson, 20 Oct 1983 (NSW); $4.5 \mathrm{~km}$ along track from Mount Ragged turnoff towards Israelite Bay, Hill 259 \& Johnson, 20 Oct 1983 (NSW); 25.0 km S of highway on track to Eyre telegraph station (now Eyre bird observatory), Hill 2176 \& Johnson, 3 Nov 1986 (NSW, CANB, MEL, PERTH); $9.2 \mathrm{~km}$ south of highway on Mason Bay road (south of Bandalup Hill), Hill 2365, Johnson, Blaxell \& Brooker, 9 Nov 1986 (NSW, CANB, MEL, PERTH); 9.3 km W of Ravensthorpe to Hopetoun road, on Road 11, Hill 2373, Johnson, Blaxell \& Brooker, 9 Nov 1986 (NSW, PERTH); Hamersley Inlet, at picnic area, Hill 3151, 7 Sep 1988 (NSW, CANB, PERTH); 2 miles [3.2 km] N of Ravensthorpe, Johnson W 225, 19 Dec 1960 (NSW); $33.5 \mathrm{~km} \mathrm{~W} \mathrm{of} \mathrm{the} \mathrm{ruins} \mathrm{at} \mathrm{Israelite}$ Bay, Pryor 183 \& J. Briggs, 26 Oct 1978 (CANB, NSW).

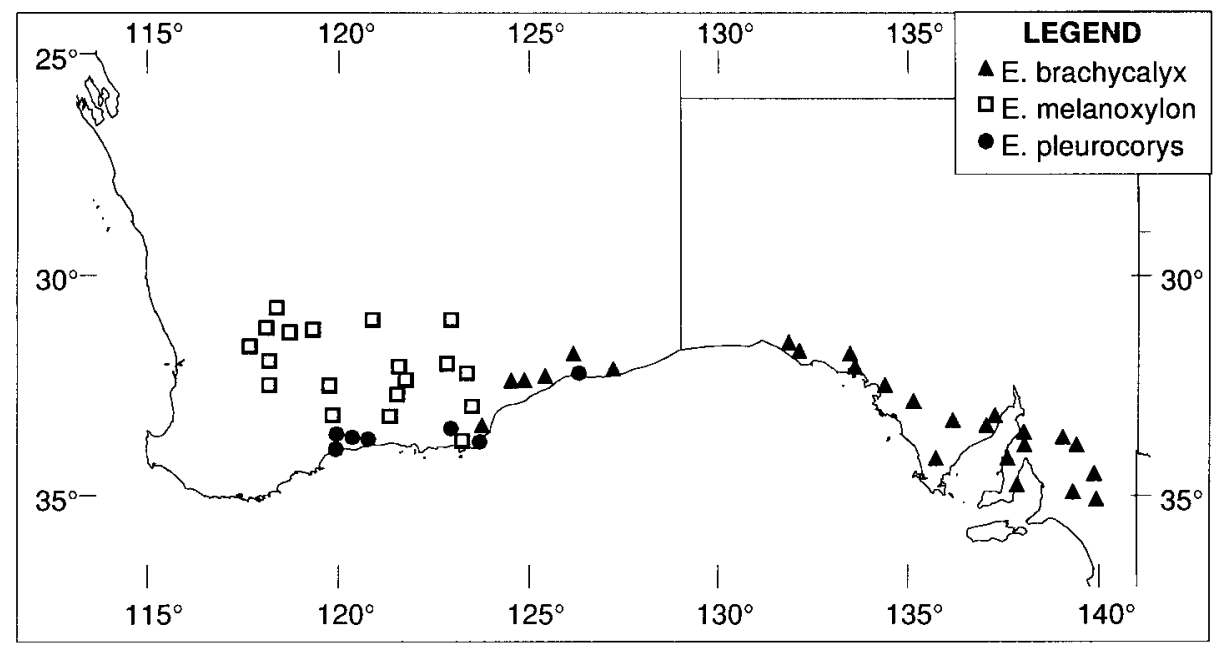

Fig. 9. Distribution of E. brachycalyx, E. melanoxylon, E. pleurocorys. 


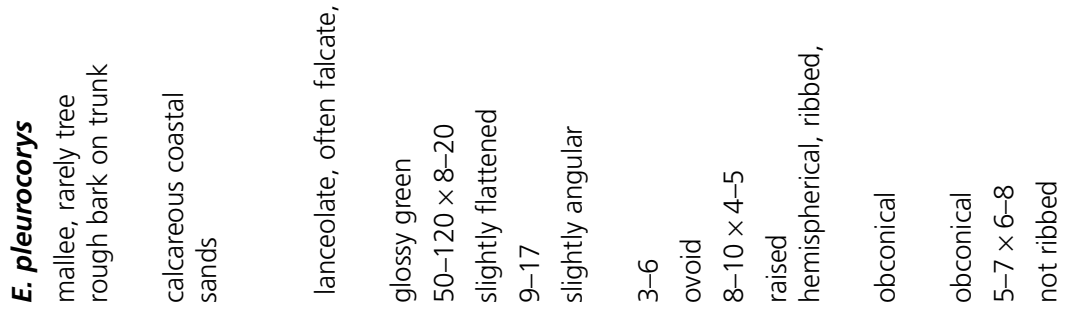

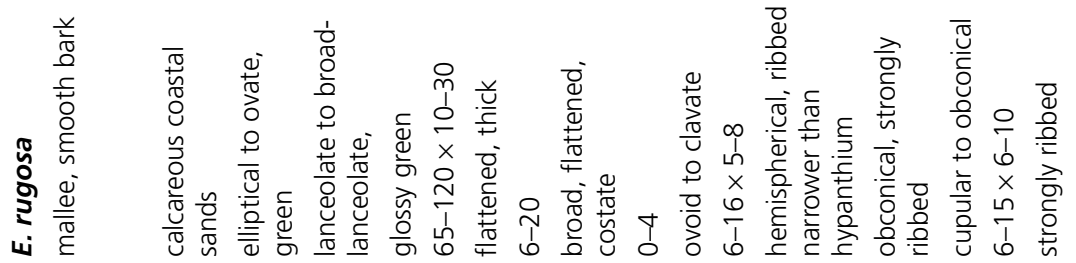

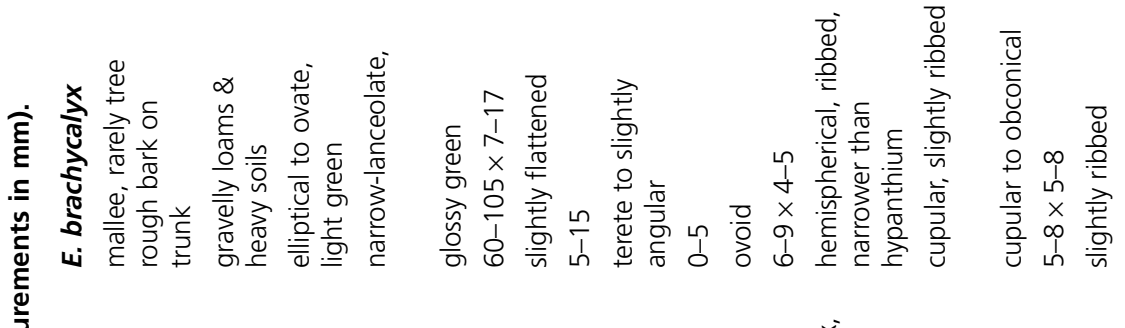

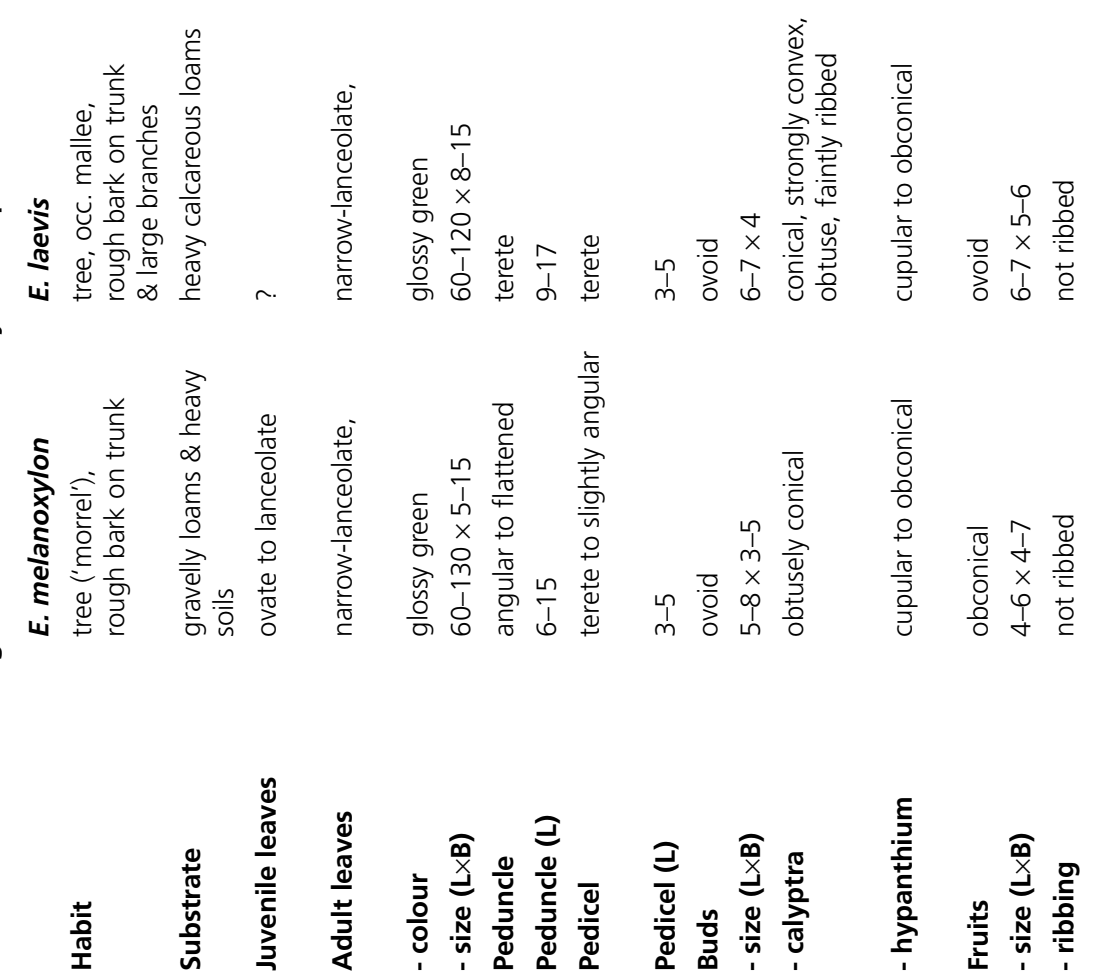




\section{Intergrades: E. brachycalyx $\leftrightarrow$ E. pleurocorys}

Specimens examined: Western Australia: $15.2 \mathrm{~km} \mathrm{~S}$ of highway on track to Eyre telegraph station (now Eyre bird observatory), Hill 2173 E Johnson, 3 Nov 1986 (NSW, CANB, MEL, PERTH).

\section{Eucalyptus trachybasis L.A.S. Johnson \& K.D. Hill, sp. nov.}

E. planipedis affinis sed alabastris fructibusque in pedunculo pedicellisque minus applanatis, et cortice plus minusve persistenti distinguitur. Ramuli saepe plus minusve pruinosi (haud in E. planipede). Umbellastrae triflorae ambas species ab E. concinna (non pruinosa) distingunt.

Type: Western Australia: $5.0 \mathrm{~km}$ N. of Widgiemooltha on highway (31 $\left.27^{\prime} \mathrm{S}, 1^{\circ} 1^{\circ} 04^{\prime} \mathrm{E}\right)$, K.D. Hill 2639 E L.A.S. Johnson, 27 Nov 1986 (holo NSW; iso PERTH).

Tree to $10 \mathrm{~m}$ tall, sometimes several-stemmed; bole short, branches spreading. Bark persistent, grey, fibrous-flaky at base (to 2-4 m); smooth, grey, often mottled brown or reddish above. Twigs usually pruinose. Juvenile leaves not seen. Adult leaves disjunct, narrow-lanceolate to lanceolate, often falcate, glossy bright green, acute or acuminate, 5.0-14.0 cm long, $0.8-2.9 \mathrm{~cm}$ wide; petioles terete, $0.9-1.8 \mathrm{~cm}$ long; lateral veins at $30-45^{\circ}$ to midrib, moderately spaced; intramarginal vein $0.5-1.0 \mathrm{~mm}$ from margin, present but obscure. Umbellasters axillary, 3-flowered. Peduncles terete to slightly flattened apically, 5-10 mm long. Pedicels flattened, 3-7 mm long. Mature buds pyriform to clavate, $8-13 \mathrm{~mm}$ long, 7-10 $\mathrm{mm}$ diam.; calyptra hemispherical to patelliform, distinctly regularly costate, c. $1 / 3-1 / 2$ as long as hypanthium, distinctly wider than hypanthium. Fruits obconical, tapered into pedicel, irregularly costate, 3-4-locular, 8-11 mm long, 8-10 mm diam.; calyptra scar and stemonophore flat or slightly raised, 1-1.5 mm wide; disc level to depressed to c. $45^{\circ}, 1.5-3 \mathrm{~mm}$ wide, valves narrowly triangular, acuminate, basally enclosed, apically ultimately vertically exserted, often broken at disc level. Seeds ovoid, smooth, shallowly and regularly pitted, dark grey- to red-brown, 1.5-2.0 mm long; hilum ventral; chaff dark red-brown, smaller, angular (Fig 10a, b, c).

Distinguished from E. planipes by the smaller buds and fruits with more slender and less flattened peduncles and pedicels, and the stocking of persistent bark. Twigs are also often weakly pruinose in E. trachybasis, and not so in E. planipes. The 3-flowered inflorescences separate both taxa from E. concinna (7-flowered), which is also not pruinose (see also Table 7).

Locally frequent on shallow calcareous soils on rocky greenstone ridges in the region from Widgiemooltha to north of Coolgardie (Fig. 11). Often locally dominant in open communities with a sparse understorey, frequently with chenopods.

Conservation status: not considered to be at risk.

The epithet is from the Greek trachy-, rough, and basis, base, in reference to the characteristic stocking of rough bark.

Selected specimens (from 9 examined): Western Australia: along Kambalda Rd, 1 mile [1.6 km] N of Kambalda to Coolgardie turnoff junction, 83 miles [133.1 km] N of Norseman, Baker 14, 9 Nov 1970 (CANB, NSW); 20 miles [32 km] N of Coolgardie, Beard 6243, 9 Sep 1970 (KPBG, NSW); 10-20 km N of Widgiemooltha, Blaxell 3338484 Nov 1986 (NSW); Widgiemooltha, Carr 1247 \& Carr, 9 Apr 1969 (CANB, NSW, PERTH); 3.7 km W of Callion towards Mussons Soak, Hill 2653 \& Johnson, 28 Nov 1986 (NSW, PERTH).

\section{Eucalyptus planipes L.A.S. Johnson \& K.D. Hill, sp. nov.}

$\mathrm{Ab}$ E. griffithsii nunc separata alabastris fructibusque non glaucis et plus prominenter alatis. E. griffithsii saepe differt habitu plus minusve arborescenti et cortice prope basin plus minusve fibrosa. 


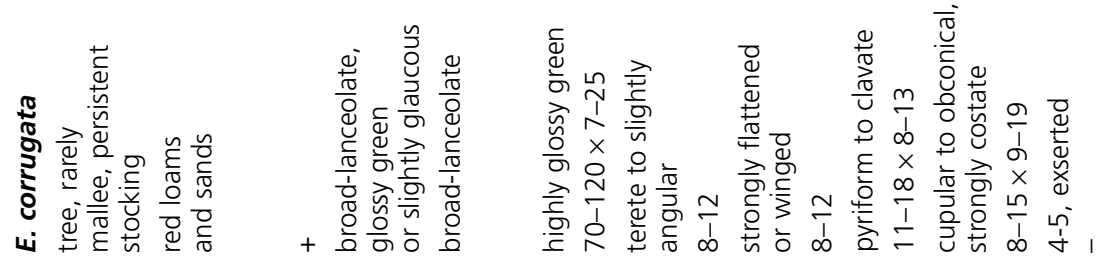
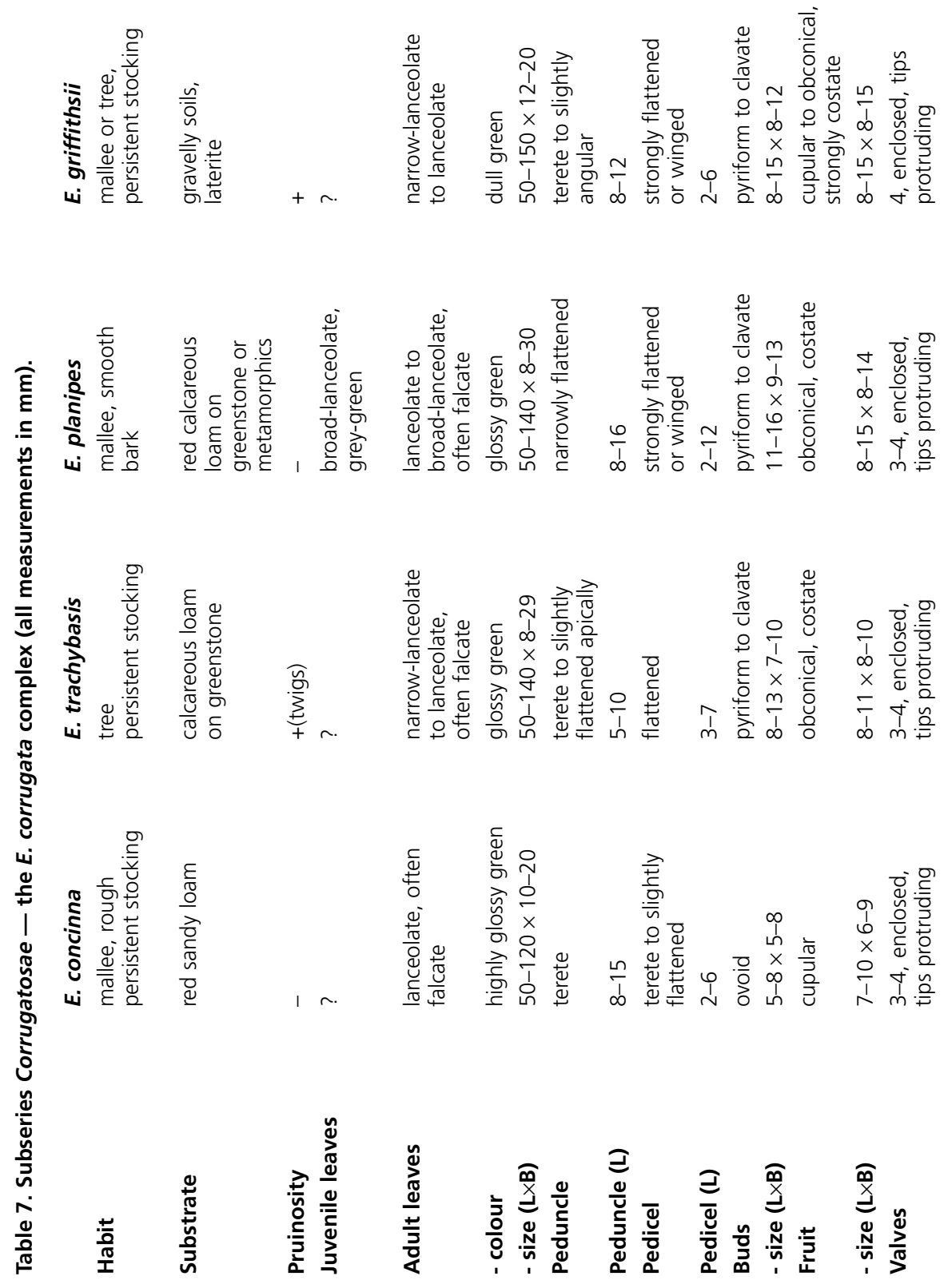
Type: Western Australia: $7.1 \mathrm{~km}$ east of Coolgardie on road to Kalgoorlie, K.D. Hill 576, L.A.S. Johnson, D.F. Blaxell, M.I.H. Brooker E S.D. Hopper, 6 Nov 1983 (holo NSW; iso CANB, PERTH).

Mallee to $8 \mathrm{~m}$ tall. Bark smooth, white or pale grey. Twigs not pruinose. Juvenile leaves disjunct, grey-green, broad-lanceolate, to $7 \mathrm{~cm}$ long, $2.5 \mathrm{~cm}$ wide, petioles to $15 \mathrm{~mm}$ long. Adult leaves disjunct, lanceolate to broad-lanceolate, often falcate, glossy bright green, acute or acuminate, $5.0-14.0 \mathrm{~cm}$ long, $0.8-3.0 \mathrm{~cm}$ wide; petioles \pm flattened, $0.9-2.5 \mathrm{~cm}$ long; lateral veins at $30-45^{\circ}$ to midrib, moderately spaced; intramarginal vein $0.5-2.0 \mathrm{~mm}$ from margin, present but obscure. Umbellasters axillary, 3-flowered. Peduncles narrowly flattened, 8-16 mm long. Pedicels strongly flattened or winged, 2-12 mm long. Mature buds pyriform to clavate, 11-16 mm long, 9-13 mm diam.; calyptra hemispherical to patelliform, distinctly regularly costate, c. $1 / 4-1 / 3$ as long as hypanthium, distinctly wider than hypanthium. Fruits obconical, tapered into
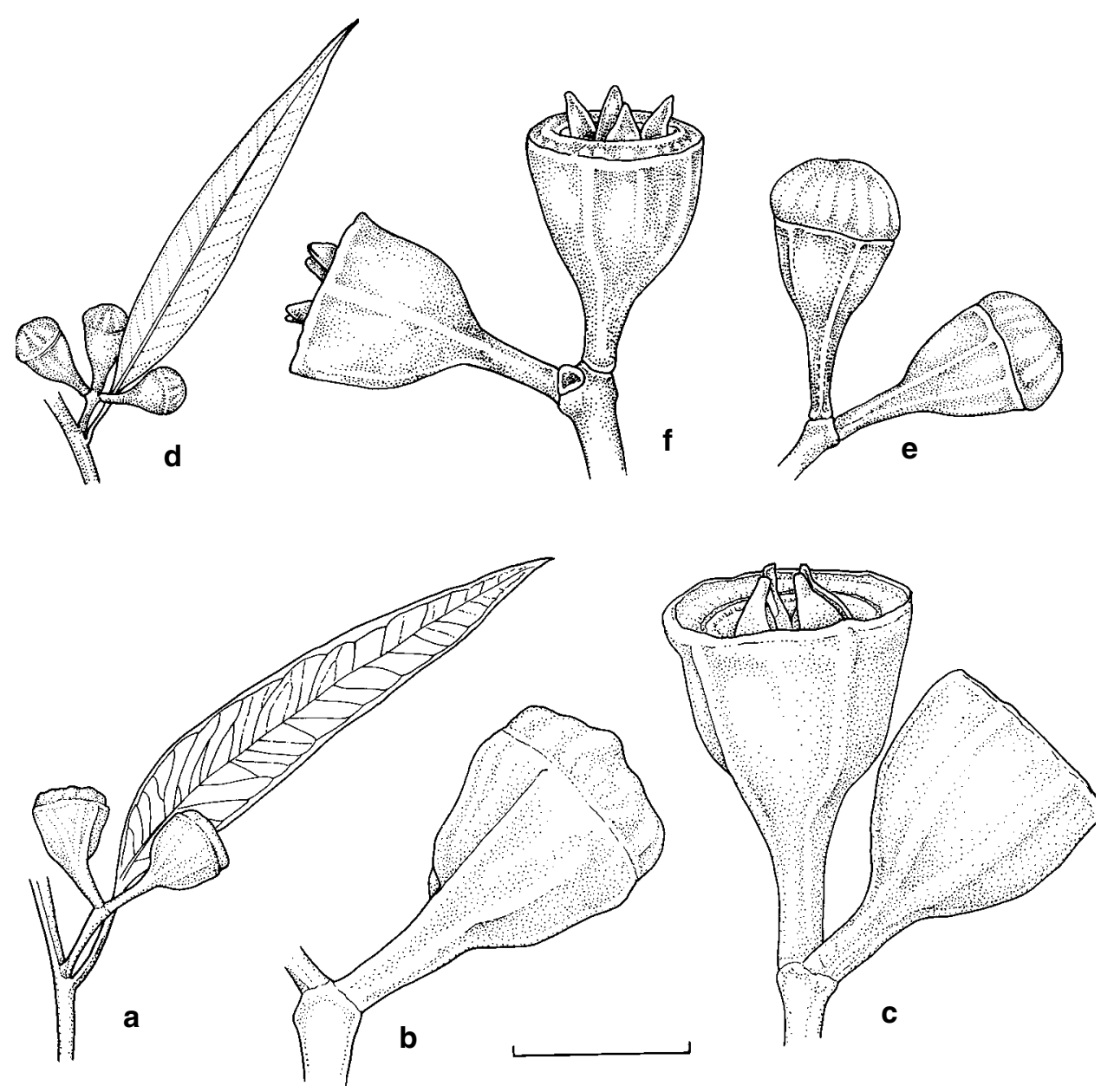

Fig. 10. E. trachybasis. a, adult leaf, inflorescence and fruits. b, inflorescence and bud. c, inflorescence and fruits. (from NSW 333848). Scale bar $=1 \mathrm{~cm}$. E. planipes. d, adult leaf, inflorescence and buds. e, inflorescence and buds. f, inflorescence and fruits. (from J. Baker 128). Scale bar $=1 \mathrm{~cm}$. 
pedicel, irregularly costate, 3-4-locular, 8-15 mm long, 8-14 mm diam.; calyptra scar and stemonophore flat or slightly raised, $1.5-2.5 \mathrm{~mm}$ wide; disc level to depressed to c. $45^{\circ}, 2-4 \mathrm{~mm}$ wide, valves narrowly triangular, acuminate, basally enclosed, apically ultimately vertically exserted, often broken at disc level. Seeds ovoid, smooth, shallowly and regularly pitted, dark grey- to red-brown, 1.5-2.5 mm long; hilum ventral; chaff dark red-brown, smaller, angular (Fig. 10d, e, f).

Previously included in a broader concept of E. griffithsii Maiden, now separated from the latter by the non-glaucous, more prominently winged, buds and fruits. E. griffithsii is also often a small tree with a short stocking of persistent fibrous bark. Individuals of E. planipes with smaller buds and fruits have also been confused with E. concinna, which is readily distinguished by the 7-flowered inflorescences (see also Table 7). Extensive intergradation occurs with E. concinna, with a spectrum of intermediate forms, and occasional intermediates are known with E. griffithsii.

Frequent on red loamy calcareous soils over metamorphics or greenstones, often a mallee among woodland trees such as E. torquata Luehm., E. clelandii (Maiden) Maiden, E. salmonophloia F. Muell., E. salubris F. Muell., E. oleosa or E. dundasii Maiden, with an open shrubby understorey often including Cratystylis and Atriplex spp.

Distributed across the region south and west of Kalgoorlie, from Norseman to around Coolgardie and some distance west of there (Fig. 11). The related E. griffithsii has a somewhat more restricted distribution around Kalgoorlie and a little further north.

Conservation status: not considered to be at risk.

The epithet is from the Latin planus, flat, and pes, foot, from the distinctively flattened pedicel.

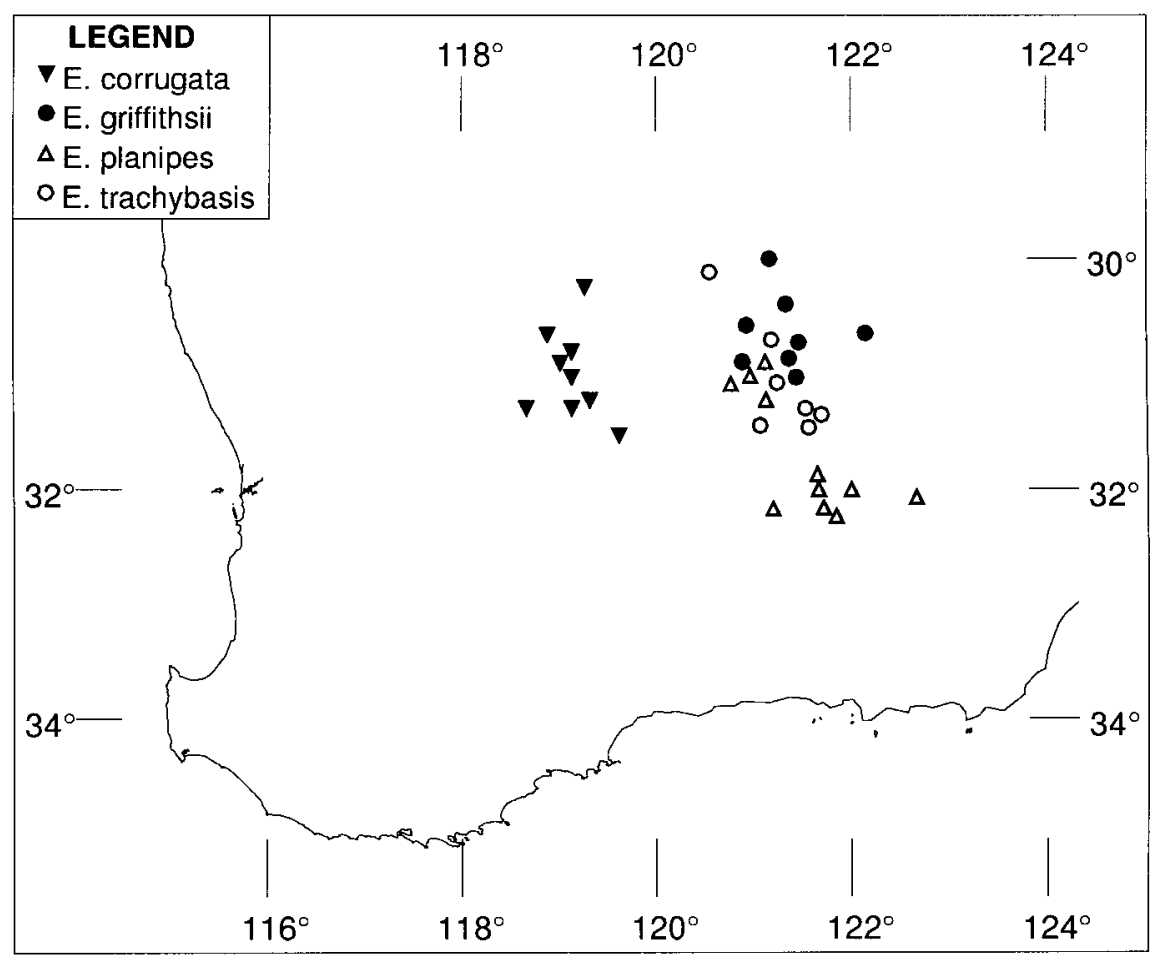

Fig. 11. Distribution of E. corrugata, E. griffithsii, E. planipes, E. trachybasis. 
Selected specimens (from 25 examined): Western Australia: 0.5 mile [0.8 km] W of Coolgardie, along Gt Eastern Highway, then (L) along Gnarlbine Rd for 7.8 miles [12.6 km], Baker 128, 23 Nov 1970 (CANB, NSW); 0.2 mile [0.4 km] (R) of Eyre Highway, 4.2 miles [6.7 km] E of Norseman, at foot of Mt Jembaluna [Mt Jimberlana], Baker 57, 13 Nov 1970 (CANB, NSW); SW of Lake Cowan, Beard 6276, 12 Sep 1970 (KPBG, NSW); c. 5 km S of Norseman on Esperance road, Blaxell 1666 \& Pryor, 21 June 1978 (NSW, PERTH); $4.6 \mathrm{~km} \mathrm{~W}$ of Bullabulling, Brooker 6398, 20 Aug 1979 (CANB, NSW, PERTH); $44.5 \mathrm{~km}$ S of Widgiemooltha, Brooker 6410, 21 Aug 1979 (CANB, NSW); Comet Hill, SW of Coolgardie, Brooker 6461, 23 Aug 1979 (CANB, NSW); 5.4 miles [8.6 km] W on road 6.8 miles [11 km] NW of Norseman, Chippendale 155, 12 Mar 1967 (CANB, NSW); 16 km SSW of Coolgardie along road to Gnarlbine Rock, Kangaroo Hills, Crisp 5617, 31 Jan 1979 (CANB, NSW, PERTH); $9 \mathrm{~km}$ east of Norseman on highway, Hill 2224 E Johnson, 4 Nov 1986 (NSW, CANB, MEL, PERTH); 9 miles [14.4 km] SW of Coolgardie, towards Gnarlbine Rocks, Phillips CBG25327, 6 Sep 1968 (CANB, NSW).

\section{Intergrades:}

E. concinna $\leftrightarrow$ E. planipes

Intergrading populations between E. concinna and E. planipes with varying degrees of backcrossing occur over a wide area in the eastern Goldfields.

Selected specimens (from 7 examined): Western Australia: 18 miles [29 km] south of Norseman towards Esperance, Brooker 2490, 15 Feb 1970 (PERTH, NSW); Grants dam, Hampton Hill Station [37 km ESE of Kalgoorlie], Coveny 8417 \& Habersley, 14 Sep 1976 (NSW, CANB, K, PERTH); 52 km E of Karonie along railway, Hill 559, Johnson, Blaxell, Brooker \& Hopper, 5 Nov 1983 (NSW, CANB, PERTH); crest of Fraser Ra, 95 km E of Norseman on Highway 1, Hill 700 \& Blaxell, 14 Nov 1983 (NSW, CANB, PERTH); $2 \mathrm{~km}$ E of Zanthus, then $29 \mathrm{~km} \mathrm{~S}$ of track towards Balladonia, Pryor $159 \mathcal{E}$ J. Briggs, 24 Oct 1978 (CANB, NSW).

E. concinna $\leftrightarrow$ (E. concinna $\leftrightarrow$ E. planipes $)$

Specimens examined: Western Australia: 7.1 miles [11.4 km] E of Karalee, Chippendale 106, 7 Mar 1967 (CANB, NSW).

(E. concinna $\leftrightarrow$ E. planipes $) \leftrightarrow$ E. planipes

Specimens examined: Western Australia: $65.5 \mathrm{~km} \mathrm{~W}$ of Balladonia roadhouse on highway, Hill 2825, 24 Aug 1988 (NSW); 40 miles [64 km] N of Kalgoorlie (35 miles [56 km] S of Menzies), Phillips CBG21974, 13 Sep 1962 (CANB, NSW).

E. griffithsii $\leftrightarrow$ E. planipes

Selected specimens (from 2 examined): Western Australia: Coolgardie, Helms 103, June 1899 (NSW).

\section{Series Leptocalyces}

Series distinguished as follows: seeds ovoid, \pm angular, black, glossy, regularly reticulate, ventral surface not ribbed; hilum paler, distinct; anthers cuboid, almost as broad as long; filaments stout, stiffly spreading, basally uniformly thick, apically abruptly narrowed to connective.

A wholly Western Australian series, here considered to consist of three species only (E. leptocalyx, E. scyphocalyx and E. platycorys).

The first taxon of this group recognised was E. scyphocalyx, as a variety of E. dumosa by Mueller, in a manuscript that was published by Bentham (1867). Bentham placed E. dumosa in series Normales subseries Robustae, which was a heterogeneous group including species from three different subgenera of those proposed by Pryor and Johnson (1971).

Maiden and Blakely (in Maiden 1929) elevated Mueller's variety to species rank, at the same time recognising the second species in the group, E. platycorys. The third species, E. leptocalyx, was recognised by Blakely (1934). 
Both Mueller (1882, 1884, 1889) and Maiden (Crit. Revis. Eucalyptus 6, 7) omitted E. dumosa and its varieties from their classification systems.

Blakely (1934) placed the three species in section Macrantherae subsection Longiores series Dumosae, but in three different subseries with other members of section Dumaria as we now recognise it (together with some species from section Bisectaria).

Pryor and Johnson (1971) placed all three species in section Dumaria series Torquatae, based in part on studies of Blakely's Dumosae by Carr and Carr (1969) and Brooker (1971). Brooker subsequently suggested further subdivision of this group on the basis of differences in seed and androecial structure $(1979,1981)$, placing the three species in series Merrickianae (and confusing E. scyphocalyx with E. merrickiae). Subsequent field studies have established the distinctive nature of these two species.

Chippendale (1988) followed Brooker (1979), but recognised E. scyphocalyx and E. merrickiae as distinct species, and formally erected series Merrickianae to accommodate the three taxa here included in series Leptocalyces together with the quite distinct E. merrickiae. Brooker (2000) coined the series name Furfuraceae for the group as constituted herein.

We now recognise the three species as distinct and closely related, but with clinal patterns of intergradation and considerable geographic variation that can be recognised at intraspecific rank. The series Leptocalyces is limited to only these three species, and this account concludes our revisionary studies of this series.

\section{Eucalyptus leptocalyx Blakely, Key Eucalypts: 118 (1934).}

Type: Western Australia: Nine-mile tank from Hopetoun, J.H. Maiden, Nov 1909 (lecto NSW; here designated). Cited as: 'W.A. - Nine-Mile Tank from the Hopetoun, J.H. Maiden, November, 1909; Grasspatch, C.A. Gardner, No. 2221'.

Mallee to $6 \mathrm{~m}$ tall. Bark smooth, grey, pink, whitish, shedding in ribbons. Adult leaves disjunct, lanceolate, falcate, acuminate, glossy, $6.0-12.0 \mathrm{~cm}$ long, $1.0-2.0 \mathrm{~cm}$ wide; petioles terete or \pm angular, $1.5-3.0 \mathrm{~cm}$ long; lateral veins at c. $30^{\circ}$ to midrib, moderately spaced, irregular and \pm obscure; intramarginal vein c. $1.0-1.5 \mathrm{~mm}$ from margin. Umbellasters axillary, 7-11-flowered. Peduncles terete to slightly flattened, 6-11 mm long. Pedicels terete or \pm angular, $2-4 \mathrm{~mm}$ long. Mature buds ovoid, $7-10 \mathrm{~mm}$ long, 4-8 mm diam.; calyptra conical, strongly convex, obtuse, smooth to faintly ribbed, c. $1 / 2$ as long as hypanthium. Fruits ovoid to cup-shaped, apically constricted, 3-4-locular, 6-10 mm long, 5-8 $\mathrm{mm}$ in diameter; calyptra scar and stemonophore flat, 0.5-1.0 mm wide; disc vertically depressed, c. $1.0 \mathrm{~mm}$ wide; valves deeply enclosed. Seeds \pm flattened, angular; semi-glossy grey-black, shallowly and regularly reticulate, c. $1.5 \mathrm{~mm}$ long; hilum ventral; chaff smaller, angular, glossy red-brown.

Distinguished within the series by the following: umbellasters 7-11 flowered; buds small, ovoid, green; calyptra hemispherical to conical, as wide as hypanthium, not ribbed; fruits small, ovoid.

Two subspecies are recognised.

\section{A. Eucalyptus leptocalyx Blakely subsp. leptocalyx}

Mallee to $5 \mathrm{~m}$ tall. Adult leaves $6.0-12.0 \mathrm{~cm}$ long, $1.0-3.4 \mathrm{~cm}$ wide; petioles terete or \pm angular, $0.9-2.7 \mathrm{~cm}$ long. Umbellasters axillary, 7-11-flowered. Peduncles angular, apically flattened, 3-11 mm long, to $4 \mathrm{~mm}$ wide. Pedicels $2-4 \mathrm{~mm}$ long. Mature buds 8-11 mm long, 6-8 mm diam.; calyptra smooth or faintly ribbed. Fruits 7-11 mm long, 6-9 mm diam. 
Frequent in mixed mallee shrubland on medium sandy soils from Fitzgerald River to Israelite Bay and probably east of there, usually near the coast, but not on coastal formations (Fig. 12).

Conservation status: not considered to be at risk.

Selected specimens (from 28 examined): Western Australia: 25 miles [40 km] NE of Condingup, Beard 6353, 16 Sep 1970 (KPBG, NSW); Fitzgerald River National Park, Hamersley Drive 14.1 km S of Old Ongerup road, Briggs 7690, 7691, 7692, 7695 \& Johnson, 9 Oct 1984 (NSW, CANB, PERTH); 4 road miles [6.4 km] south of the Norseman to Esperance Road on turnoff to Ravensthorpe, Brooker 3603, 21 Apr 1972 (CANB, NSW); 12.1 km E of Telegraph track on Hamersley Drive, Fitzgerald [National Park], Brooker 8763, 18 Dec 1984 (CANB, NSW); $8.4 \mathrm{~km}$ from Israelite Bay track on Mt Ragged track, Brooker 8916, 8 Apr 1985 (CANB, NSW); 5.3 km N of Jerdacuttup North road towards Bandalup Hill, Brooker 8940, 11 Apr 1985 (CANB, NSW); corner of Murray and Gordon Inlet roads, Brooker 9855, 12 Jan 1988 (CANB, NSW); 45.1 miles [72.7 km] E of Esperance, Chippendale 407, 25 Mar 1968 (CANB, NSW); 15.4 miles [25 km] SSE of Ravensthorpe, Chippendale 418, 26 Mar 1968 (CANB, NSW); near junction of Exchange Road and Merivale Road, 8-10 km south of Esperance to Israelite Bay Road (towards Cape Arid National Park), Foreman 1297, 28 Nov 1985 (MEL, CANB, NSW, PERTH); $3.1 \mathrm{~km}$ past Mt Ragged turnoff on track to Israelite Bay from Balladonia, Hill 258 \& Johnson, 20 Oct 1983 (NSW, PERTH); Devil's Creek Rd, 10.0 km NW of Fitzgerald Nat. Park entrance, Hill 3114, 6 Sep 1988 (NSW); 9 m. [9 mile=14.4 km] tank from Hopetoun, Maiden s.n., Nov 1909 (NSW 17786); $22.2 \mathrm{~km} \mathrm{~W}$ of the ruins at Israelite Bay, Pryor 182 $\mathcal{E}$ J. Briggs, 26 Oct 1978 (CANB, NSW).

11B. Eucalyptus leptocalyx Blakely subsp. petilipes L.A.S. Johnson E K.D. Hill, subsp. nov.

$\mathrm{Ab}$ subspecie leptocalyce fructibus minoribus et ovideis, pedunculi pedicellique longi tenuesque, et foliis alabastrisque aliquanto minora distinguitur.

Type: Western Australia: $5 \mathrm{~km}$ NW of Coolinup Road on Kau Rock Road, NE of

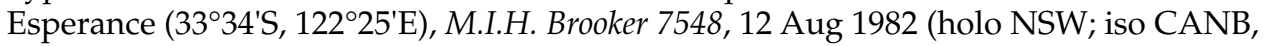
PERTH).

Mallee to $6 \mathrm{~m}$ tall. Adult leaves $6.0-12.0 \mathrm{~cm}$ long, 1.0-2.0 cm wide; petioles terete, 1.5-3.0 cm long. Umbellasters axillary, 7-flowered. Peduncles terete to slightly flattened, 6-11 mm long. Pedicels 2-4 mm long. Mature buds 7-9 mm long, 4-5 mm diam.; calyptra faintly ribbed. Fruits 6-9 mm long, 5-8 mm diam. (Fig. 14).

Subsp. petilipes differs from subsp. leptocalyx in the smaller, ovoid fruits with long, slender pedicels and peduncles, and the generally smaller leaves and buds.

This subspecies occurs on light soils on slightly elevated sites, in mixed mallee shrubland, frequently associated with E. uncinata Turcz. and E. indurata Brooker \& Hopper. To date, it is known from a small area north east of Esperance and slightly inland (Fig. 12). This region is poorly explored, and extensions of range are probable.

Intermediate populations between E. leptocalyx and E. scyphocalyx occur north of Esperance (around Salmon Gums). Although intermediate in most characters, these populations are often much coarser in foliage characters than either parent. These are stable breeding populations with their own unique genetic makeup developed from a mixing of the parent species.

Conservation status: not considered to be at risk.

The epithet is from the Latin petilis, slender, and pes, foot, from the slender pedicel.

Selected specimens (from 8 examined): Western Australia: 20 miles [32 km] NE of Mt Ney, Beard 6386, 17 Sep 1970 (KPBG, NSW); 4 km along Mt Ney Rd NE of Kau Rock Rd turnoff, NE of Esperance, Brooker 8164, 5 June 1983 (CANB, NSW); 19.9 km NE from Mt Ridley turnoff on Dempster road, Brooker 8921, 9 Apr 1985 (CANB, NSW); 44.4 km NE of Logans road on Mt Ney road, Hill 2263 \& Johnson, 5 Nov 1986 (NSW, CANB, MEL, PERTH); $15.3 \mathrm{~km} \mathrm{SE}$ of Mt Ney road on Clyde Rock road, Hill 2271 \& Johnson, 6 Nov 1986 (NSW, CANB, MEL, PERTH). 
Intergrades: E. leptocalyx subsp. leptocalyx $\leftrightarrow$ E. leptocaly $x$ subsp. petilipes

Selected specimens (from 3 examined): Western Australia: $26.2 \mathrm{~km}$ from Mt Burdett towards Mt Ney, Brooker 7090, 11 Nov 1981 (CANB, NSW, PERTH); 5 km NW of Coolinup Rd on Kau Rock Rd, NE of Esperance, Brooker 7548, 12 Aug 1982 (CANB, NSW); Mt Burdett about 50 km north east of Esperance, Foreman 1232, 26 Nov 1985 (MEL, AD, CANB, NSW, PERTH).

\section{Intergrades between species in Series Leptocalyces}

E. leptocalyx $\leftrightarrow$ E. scyphocalyx

Selected specimens (from 15 examined): Western Australia: 5 miles [8 km] E of Scaddan, Beard 6345, 15 Sep 1970 (KPBG, NSW); 38 miles [61.2 km] south of Salmon Gums, Brooker 2773, 8 Aug 1970 (PERTH, NSW); 0.5 mile [0.8 km] N of Grasspatch, Chippendale 394, 24 Mar 1968 (CANB, NSW); 5 miles [8 km] S of Salmon Gums, Johnson W 192, 18 Dec 1960 (NSW); Pullitup Swamp area, at SE corner of Fitzgerald River National Park, c. $10 \mathrm{~km}$ NE of Bremer Bay, Pullen 10,042, 15 Dec 1974 (CANB, NSW); 3.6 km S from Rollonds road on Fields road, Hill 2307, Johnson \& Blaxell, 7 Nov 1986 (NSW, PERTH).

E. leptocalyx subsp. petilipes $\times$ E. scyphocaly $x$ subsp. triadica

Specimens examined: Western Australia: $13 \mathrm{~km}$ NE of Mt Ridley turnoff on Dempster road, Brooker 8793, 16 Jan 1985 (CANB, NSW).

12. Eucalyptus scyphocalyx (F. Muell. ex Benth.) Maiden \& Blakely, Crit. Revis. Eucalyptus 8: 45 (1929). Figured in Crit. Revis. Eucalyptus 1, Plate 3, fig. 5.

= Eucalyptus dumosa A. Cunn. ex Schauer var. scyphocalyx F. Muell. ex Benth., Fl. Austral. 3: 230 (1867).

Type: Western Australia: Eyre's Relief, Maxwell s.n. (lecto K?, here designated; isolecto MEL?, NSW). The original citation was: 'W. Australia, Eyre's Relief, Maxwell. Another form, very much like this one, but with longer, not much flattened peduncles, and the fruit nearly $1 / 2$ in. long, in Herb. R. Br., gathered in Baudin's Expedition on the Ile les Amiraux.' Maiden and Blakely elevated the variety to specific rank, stating 'it has only been found at Eyre's Relief Camp, Great Australian Bight, Western Australia. Collector not known.' They thus knowingly, or unknowingly, excluded the specimen in Herb. R. Br. cited by Bentham. In order to avoid any future confusion, the Maxwell specimen is here designated the Lectotype. This species has not been confirmed at this site subsequently, and it must be assumed that some confusion exists over the original site of Maxwell's collection.

Maiden initially included this taxon in E. incrassata (Crit. Revis. Eucalyptus 1903-1933, 1: 97), although he later reconsidered, and Maiden and Blakely elevated it to specific rank. Gardner (1960) regarded it as synonymous with E. merrickiae although this view was not generally followed.

Mallee to $6 \mathrm{~m}$ tall, rarely a small tree. Bark smooth, grey, pink, whitish, shedding in ribbons, rarely with a short basal stocking of persistent fibrous bark. Juvenile leaves disjunct, ovate, grey-green, dull, to $8 \mathrm{~cm}$ long, $4 \mathrm{~cm}$ wide. Adult leaves disjunct, lanceolate to broad-lanceolate, often falcate, acuminate, more or less glossy, $4.0-120.0 \mathrm{~cm}$ long, $0.8-2.5 \mathrm{~cm}$ wide; petioles terete or \pm angular, $0.8-2.0 \mathrm{~cm}$ long; lateral veins at c. $30-40^{\circ}$ to midrib, moderately spaced, irregular and \pm obscure; intramarginal vein c. 1-2 mm from margin. Umbellasters axillary, 3-7-flowered. Peduncles terete or angular, 5-13 mm long. Pedicels terete or \pm angular, 1-7 mm long. Mature buds ovoid, often distinctly red or cream, 8-12 mm long, 6-8 mm diam.; calyptra shallowly hemispherical, sometimes broadly apiculate, smooth or faintly ribbed, $1 / 3-1 / 2$ as long as hypanthium, wider than hypanthium. Fruits ovoid to cup-shaped or campanulate, 3-4-locular, 8-12 mm long, 7-11 mm in diameter; calyptra scar and stemonophore flat, 0.5-1.0 mm wide; disc steeply depressed, 1-2 mm wide; valves deeply enclosed. Seeds 
\pm pyramidal, angular; semi-glossy grey-black, shallowly and regularly reticulate, $2-3 \mathrm{~mm}$ long; hilum ventral; chaff smaller, angular, red-brown.

Two geographic subspecies are recognised, as below.

Hybrids are recorded between E. platycorys and both subspecies.

12A. Eucalyptus scyphocalyx (F. Muell ex Benth.) Maiden E Blakely subsp. scyphocalyx

Adult leaves lanceolate to broad-lanceolate, glossy to semiglossy, 4.0-12.0 cm long, 0.8-2.5 cm wide; petioles 0.8-2.2 cm long. Umbellasters 7-flowered. Peduncles 3-13 mm long. Pedicels 1-7 mm long. Mature buds $8-12 \mathrm{~mm}$ long, 6-8 $\mathrm{mm}$ diam. Fruits ovoid to cup-shaped or campanulate, smooth or shallowly ribbed, 8-12 mm long, 7-11 mm diam.

Locally frequent on grey or white sandy soils over laterites on flat country in the area from Jerramungup to Ravensthorpe and northeast towards Salmon Gums, occupying a zone to the north and west of E. leptocalyx subsp. leptocalyx (Figs. 12, 13). Associated species include E. uncinata, E. cylindriflora Maiden \& Blakely, E. calycogona Turcz., E. eremophila (Diels) Maiden and E. spathulata Hook.

Conservation status: not considered to be at risk.

Selected specimens (from 15 examined): Western Australia: $29 \mathrm{~km} \mathrm{~W}$ of Jerramungup, Brooker 8373, 23 Nov 1983 (CANB, NSW); E side of Lake Magenta, NE of farmhouse, Brooker 8783, 14 Jan 1985 (CANB, NSW); $37 \mathrm{~km}$ SE of Lake King, North road, $6 \mathrm{~km}$ N of junction with Hayes Road, Crisp 4994, 10 Jan 1979 (CANB, NSW, PERTH); 17 km S of Pingrup on rd to Ongerup, Hill 329, Johnson $\mathcal{E}$ Blaxell, 23 Oct 1983 (NSW, CANB, PERTH); $47.8 \mathrm{~km}$ past Fields road (5 ways) on Ravensthorpe track, Hill 2342, Johnson \& Blaxell, 8 Nov 1986 (NSW, PERTH); $5.2 \mathrm{~km} \mathrm{~W}$ of Giles road (Findley road), on Magenta road, Hill 2399, Johnson, Blaxell \& Brooker, 10 Nov 1986 (NSW, PERTH); 100 m S of S shore of Lake Chinocup, Hill 2461, Johnson \& Blaxell, 13 Nov 1986 (NSW, PERTH); $43.8 \mathrm{~km}$ N of Lake King to Norseman rd on Rabbit Proof Fence rd, Hill 3045, 1 Sep 1988 (NSW); 6.7 km E on Needilup Nth Rd on Ryans Rd, Hill 3137, 7 Sep 1988 (NSW).

12B. Eucalyptus scyphocalyx (F. Muell ex Benth.) Maiden E Blakely subsp. triadica L.A.S. Johnson E K.D. Hill, subsp. nov.

$\mathrm{Ab}$ subspecies scyphocalyx umbellastris trifloras, fructus aliquanto breviores et distincte costati distinguitur.

Type: Western Australia: $15.3 \mathrm{~km}$ south-east of Mount Ney road on Clyde Rock road, K.D. Hill 2268 E L.A.S. Johnson, 6 Nov 1986 (holo NSW; iso CANB, MEL, PERTH).

Adult leaves lanceolate, semiglossy, $5.0-12.0 \mathrm{~cm}$ long, $1.0-2.2 \mathrm{~cm}$ wide; petioles $1.0-2.2 \mathrm{~cm}$ long. Umbellasters 3-flowered. Peduncles 3-10 mm long. Pedicels 1-7 mm long. Mature buds 8-12 mm long, 6-8 mm diam. Fruits cup-shaped or campanulate, often distinctly shallowly ribbed, 8-12 mm long, 8-11 mm diam. (Fig. 15).

Three-flowered umbellasters readily distinguish subsp. triadica from the type subspecies. Fruits also tend to be more squat and more distinctly ribbed, and foliage is less coarse.

Locally frequent on loamy calcareous soils in flat country in the area northeast of Esperance, in a zone lying to the east of subsp. scyphocalyx and to the north of E. leptocalyx subsp. petilipes (Fig. 13). Associated species include E. uncinata, E. ovularis Maiden \& Blakely, E. oleosa, E. eremophila and E. gracilis.

Conservation status: not considered to be at risk.

The epithet is from the Latin triad, a group of three, from the 3-flowered inflorescences. 


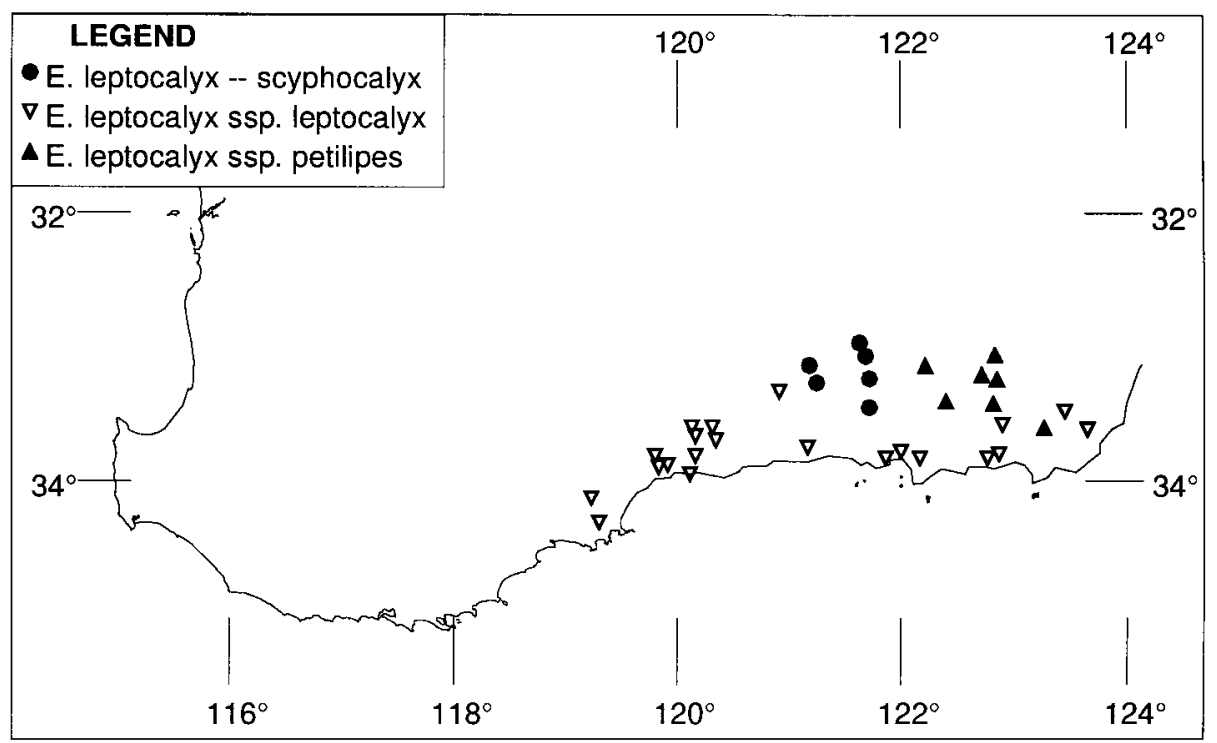

Fig. 12. Distribution of E. leptocalyx subspp. leptocalyx and petilipes, E. leptocalyx - scyphocalyx intergrades.

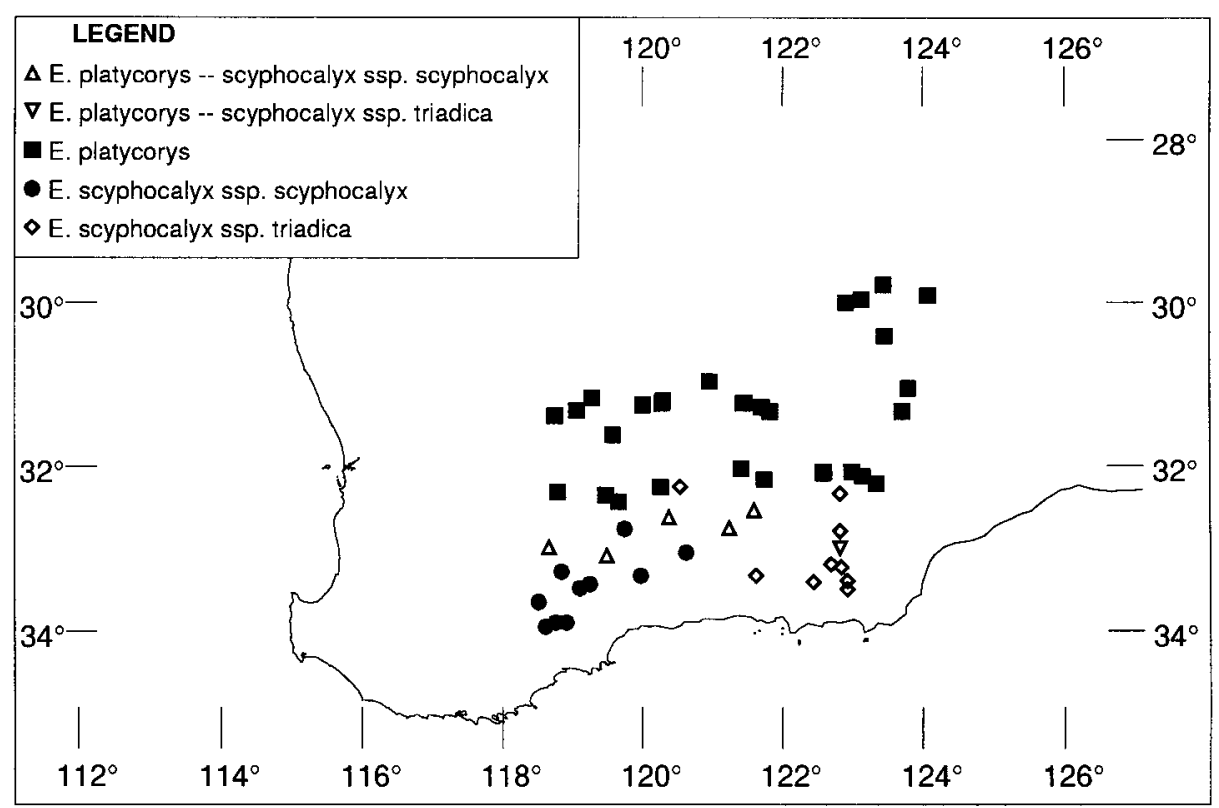

Fig. 13. Distribution of E. platycorys, E. scyphocalyx subspp. scyphocalyx and triadica, E. platycorysE. scyphocalyx subsp. scyphocalyx intergrades and E. platycorys-E. scyphocalyx subsp. triadica intergrades. 

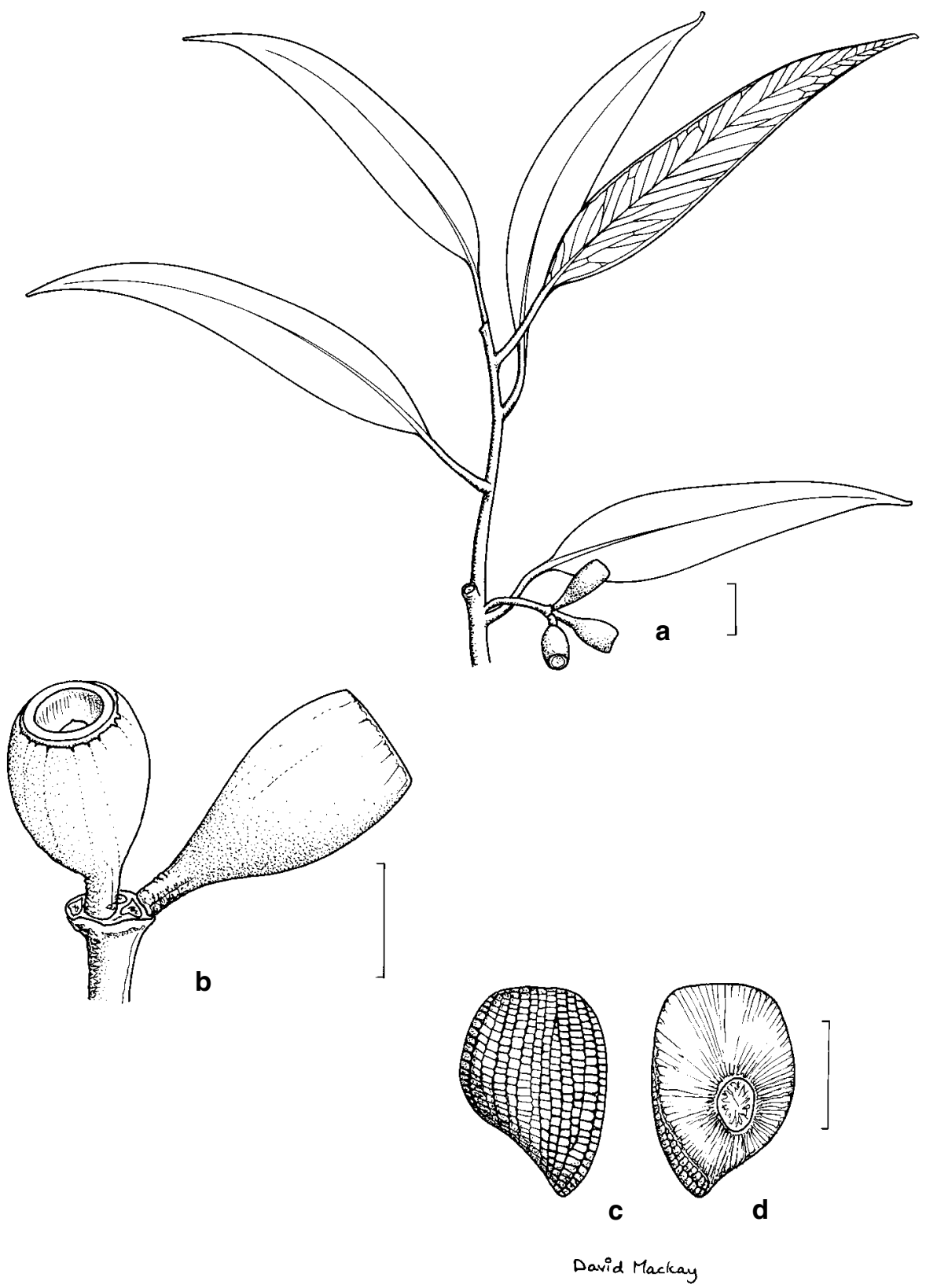

Fig. 14. E. leptocalyx subsp. petilipes. $\mathbf{a}$, adult leaves; inflorescence and fruits; $\mathbf{b}$, inflorescence and fruits; c, d, seed. (from Brooker 8921). Scale bars: a, b, =1 cm; c, d =1 mm. 
Selected specimens (from 15 examined): Western Australia: Southern Hills Station, Beard 6307, 13 Sep 1970 (KPBG, NSW); 30 miles [48 km] NE of Condingup, Beard 6357, 16 Sep 1970 (KPBG, NSW); 30 miles [48 km] NE of Mt Ney, Beard 6375, 17 Sep 1970 (KPBG, NSW); $6.6 \mathrm{~km}$ E of Truslove, Brooker 7080, 10 Nov 1981 (CANB, NSW); $35.6 \mathrm{~km}$ along Howick rd to NW of Muntz rd crossing, E of Esperance, Hill 288 \& Johnson, 21 Oct 1983 (NSW, CANB, PERTH); $132.0 \mathrm{~km} \mathrm{~W}$ of Coolgardie to Norseman rd on Hyden track, Hill 2868, 25 Aug 1988 (NSW, CANB, PERTH).

\section{Intergrades and hybrids:}

E. scyphocalyx subsp. scyphocalyx $\leftrightarrow$ E. scyphocalyx subsp. triadica

Selected specimens (from 2 examined): Western Australia: Double Tank, between Fraser Range and Esperance, Beard 6332, 13 Sep 1970 (KPBG, NSW); $177.1 \mathrm{~km} \mathrm{~W}$ of Norseman to Coolgardie rd on Hyden track (20.7 km E of crossroads), Hill 2875, 26 Aug 1988 (NSW);

\section{E. platycorys $\leftrightarrow$ E. scyphocalyx subsp. scyphocalyx}

Selected specimens (from 6 examined): Western Australia: 7.4 miles [11.8 km] W of Lake King village on main road from Newdegate, Tindale 3776, 28 Aug 1973 (NSW); $30 \mathrm{~km} \mathrm{~W} \mathrm{of} 90$ mile tank, Aplin 5922, June 1974 (PERTH, NSW); 1 mile [1.6 km] north of Burngup, Brooker 2276, 5 Nov 1969 (PERTH, NSW); road to Peak Charles, Brooker 7503, 2 May 1982 (CANB, NSW); $43.4 \mathrm{~km} \mathrm{~S}$ of Norseman on Esperance highway, Hill 2229, Johnson, Brooker \& Blaxell, 5 Nov 1986 (NSW, PERTH, CANB, MEL, CANB).

E. platycorys $\leftrightarrow$ E. scyphocalyx subsp. triadica

Specimens examined: Western Australia: $44.4 \mathrm{~km} \mathrm{NE}$ of Logans road on Mt Ney road, Hill 2262 $\mathcal{E}$ Johnson, 5 Nov 1986 (NSW, PERTH, CANB, MEL, CANB).

E. deflexa $\times($ E. platycorys $\leftrightarrow$ E. scyphocalyx $)$

Specimens examined: Western Australia: $0.5 \mathrm{~km} \mathrm{~W}$ of Hatters Hill road, on Lake King road, Hill 2350, Johnson, Blaxell \& Brooker, 8 Nov 1986 (NSW).

\section{E. deflexa $\times$ E. scyphocalyx}

Specimens examined: Western Australia: c. $200 \mathrm{~m} \mathrm{~W}$ of Hatters Hill road on Lake King to Norseman road, Brooker 8765, 18 Dec 1984 (CANB, NSW).
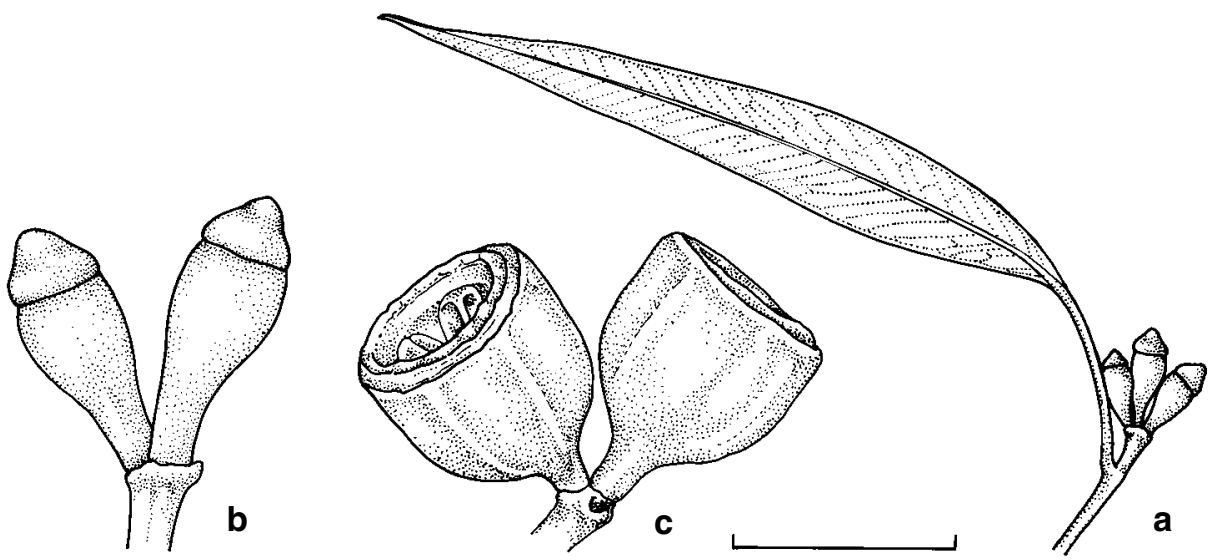

Fig. 15. E. scyphocalyx subsp. triadica. $\mathbf{a}$, adult leaf, inflorescence and buds; $\mathbf{b}$, inflorescence and buds; c, inflorescence and fruits. (a from Hill 2868, b from Johnson 228, c from Hill 2864). Scale bar $=1 \mathrm{~cm}$. 
Table 8. Published names in Series Obtusiflorae (accepted names in Bold type, taxonomic synomyms represented by ' $=$ ', nomenclatural synonyms represented by ' $\equiv$ ').

E. obtusiflora DC., Prodr. 3: 220 (1828).

E. dumosa A. Cunn. ex Oxley, J. Two Exped. 63 (1820); Schauer in Walp., Repert. Bot. Syst. 2: 925 (1843).

E. lamprocarpa F. Muell. ex Miq., Ned. Kruidk. Arch. 4: 129 (1856); = E. dumosa.

E. muelleri Miq., Ned. Kruidk. Arch. 4: 130 (1856); = E. dumosa.

E. dumosa A. Cunn. ex Schauer var. conglobata R. Br. ex Benth., Fl. Austral. 3: 230 (1867); 三E. conglobata.

E. incrassata Labill. var. dumosa (A. Cunn. ex Schauer) F. Muell., Eucalyptographia, Dec. 5 (1879-1884);

$\equiv$ E. dumosa.

E. incrassata Labill. var. conglobata (R. Br. ex Benth.) Maiden, Crit. Revis. Eucalyptus 1: 100 (1904); $\equiv$

E. conglobata.

E. striaticalyx W.V. Fitzg., J. Proc. Mueller Bot. Soc. Western Australia 1: 20 (1904).

E. woodwardii Maiden, J. Nat. Hist. Sc. Soc. Western Australia 3: 2 (1910).

E. goniantha Turcz. var. clelandii Maiden, Proc. Western Australian Nat. Hist. \& Sci. Soc. 3: 176 (1911); $\equiv$ E. clelandii.

E. clelandii (Maiden) Maiden, Crit. Revis. Eucalyptus 2: 189 (1912). Plate 69, fig. 8.

E. lesouefii Maiden, Crit. Revis. Eucalyptus 2: 187 (1914).

E. sheathiana Maiden, J. Proc. Roy. Soc. New South Wales 49: 312 (1915).

E. conglobata R. Br. ex Maiden, Crit. Revis. Eucalyptus 6: 273 (1922).

E. kondininensis Maiden \& Blakely, J. \& Proc. Roy. Soc. New South Wales 59: 189, (1925).

E. dongarraensis Maiden \& Blakely, J. \& Proc. Roy. Soc. New South Wales 59: 184 (1925); E E. obtusiflora subsp. dongarraensis.

E. pileata Blakely, Key Eucalypts, 120 (1934).

E. conglobata (R. Br. ex Benth.) Maiden subsp. fraseri Brooker, Nuytsia, 1: 251 (1972). EE. fraseri

E. fraseri (Brooker) Brooker, Australian Forest Res. 7: 65 (1976).

E. cyanophylla Brooker, Trans. \& Proc. Roy. Soc. South Australia 101(1): 15 (1977).

E. georgei Brooker \& Blaxell, Nuytsia 2(4): 224 (1978).

E. calcareana Boomsma, J. Adelaide Bot. Gard. 1(6): 361 (1979).

E. pterocarpa C. Gardner ex P. Lang, Fl. Australia 19: 510 (1988).

E. percostata Brooker \& P. Lang, J. Adelaide Bot. Gard. 13: 65 (1990).

E. cretata P. Lang \& Brooker, J. Adelaide Bot. Gard. 13: 71 (1990).

E. georgei subsp. fulgida Brooker \& Hopper, Nuytsia 9: 47 (1993).

E. tenuis Brooker \& Hopper, Nuytsia 9: 48 (1993).

E. polita Brooker \& Hopper, Nuytsia 9: 51 (1993).

\section{Series Obtusiflorae}

Treated as series Rufispermae Maiden by Chippendale (1988) and Brooker (2000).

Series distinguished as follows: seeds elliptical, dorsiventrally flattened, glossy red or red-brown, very shallowly regularly reticulate; hilum ventral, indistinct in colour.

A large and complex series with over 50 constituent species, primarily Western Australian, but with a number of species in South Australia and a few species extending into New South Wales and Victoria. Further division into subseries is somewhat problematical, and is not attempted at this stage.

The first species described in this series was E. obtusiflora DC., although confusion with the eastern Australian species E. obstans has existed since (see below). This was followed by E. dumosa, although the name E. dumosa had been published without description even earlier. E. dumosa has also been a confused concept for a long period, 
with many distinct species at one time or another being included as synonyms or varieties (e.g see Maiden, Crit. Revis. Eucalyptus 1903-1933, 1).

A large number of taxa were added during the time of Maiden and Blakely, as in many other eucalypt groups. This was followed by a period of inactivity, then a resurgence of interest with many new taxa described by various authors in the past 20 years (Table 8). The group still requires intensive study of several complexes, and additional taxa beyond the ten described below await definition.

\section{The Eucalyptus pileata complex}

This is a group of 5 species occurring in the southern wheatbelt and southern goldfields regions of Western Australia. All are trees except E. pileata Blakely, and all display distinctively smooth bark that sheds in long, durable ribbons and typically hangs in trees long after shedding. See Table 9 for species included and their identification.

13. Eucalyptus spreta L.A.S. Johnson $\mathcal{E}$ K.D. Hill, sp. nov.

$\mathrm{Ab}$ E. fraseri distinguitur: alabastra minora, saepe elongata plus minusve rostrata; fructus minores; habitu arborescenti ramis a trunco brevi adscendentibus ('marlock').

Type: Western Australia: 60 km E. of Norseman on Highway 1 (32 $04^{\prime}$ 'S 122 $\left.22^{\prime} E\right)$, K.D. Hill 692 E D.F. Blaxell, 14 Nov 1983 (holo NSW; iso CANB, K, PERTH).

[E. species U, Brooker \& Kleinig 1990: 329 (1990)]

Tree to $10 \mathrm{~m}$ tall, branched near base ('Marlock' habit). Bark smooth to base, white, grey and pink, shedding in ribbons. Juvenile leaves ovate to broad-lanceolate, dull. Adult leaves disjunct, lanceolate, acute, glossy, $6.0-12.0 \mathrm{~cm}$ long, $1.0-2.5 \mathrm{~cm}$ wide; petioles terete or \pm flattened, $0.8-2.0 \mathrm{~cm}$ long; young stems \pm quadrangular; lateral veins at c. $30-45^{\circ}$ to midrib, moderately spaced, \pm degenerate; intramarginal vein present, indistinct and slightly degenerate, $0.5-1.5 \mathrm{~mm}$ from margin. Umbellasters axillary, 7-flowered. Peduncles terete or vaguely ribbed, 3-8 $\mathrm{mm}$ long, c. $2 \mathrm{~mm}$ thick. Pedicels \pm ribbed, $0.5-2.0 \mathrm{~mm}$ long. Mature buds ovoid to \pm fusiform, $10-12 \mathrm{~mm}$ long, c. $4 \mathrm{~mm}$ diam.; calyptra conical, acute, with a pronounced median constriction, ribbed, about as long as hypanthium. Fruits obconical, 4-locular, 6-8 mm long, 6-7 mm diam.; calyptra scar and stemonophore flat, c. $0.5 \mathrm{~mm}$ wide; disc sharply depressed, $1.0-1.5 \mathrm{~mm}$ wide; valves broadly triangular, enclosed, raised at c. $45^{\circ}$. Seeds irregular, flattened, shallowly reticulate, glossy deep red brown, 1.5-2.0 mm long; hilum ventral; chaff similar, angular, smaller (Fig. 16).

E. spreta differs from E. fraseri in the smaller, often elongate and \pm rostrate buds and the smaller fruits, and the 'marlock' habit. The 'marlock' habit (a low-branching tree with steeply ascending branches and a short bole) is also different from the habit of the related taxa E. fraseri and E. valens, and foliage is also distinctively stiff and erect. E. spreta has been included in a somewhat confused concept of E. pileata to date; the latter is a mallee species from further west with distinctively clavate buds with broad, flat calyptra (see also Table 9).

Locally frequent south and east of Norseman to west of Balladonia (Fig. 17). Not well collected and probably more widespread. Hybrids with E. fraseri are known.

Restricted to woodlands on calcareous loams or sandy loams, associated with various species including E. gracilis, E. flocktoniae, E. valens and E. fraseri.

Conservation status: not considered to be at risk. 
The epithet is from the Latin spretus (past participle of spreno), separated or removed, referring to the geographic separation from E. pileata, with which has been confused in the past.

Selected specimens (from 52 examined): Western Australia: along Eyre Highway, 28.3 miles [ $52.5 \mathrm{~km}$ ] S of Norseman, Baker 65, 13 Nov 1970 (CANB, NSW); on Telegraph line, S of Fraser Range, Beard 6316, 12 Sep 1970 (KPBG, NSW); 30 miles [48 km] NE of Mt Ney, Beard 6373, 17 Sep 1970 (KPBG, NSW); 28.2 km NW of Balladonia towards Norseman, Brooker 8839, 10 Feb 1985 (CANB, NSW);

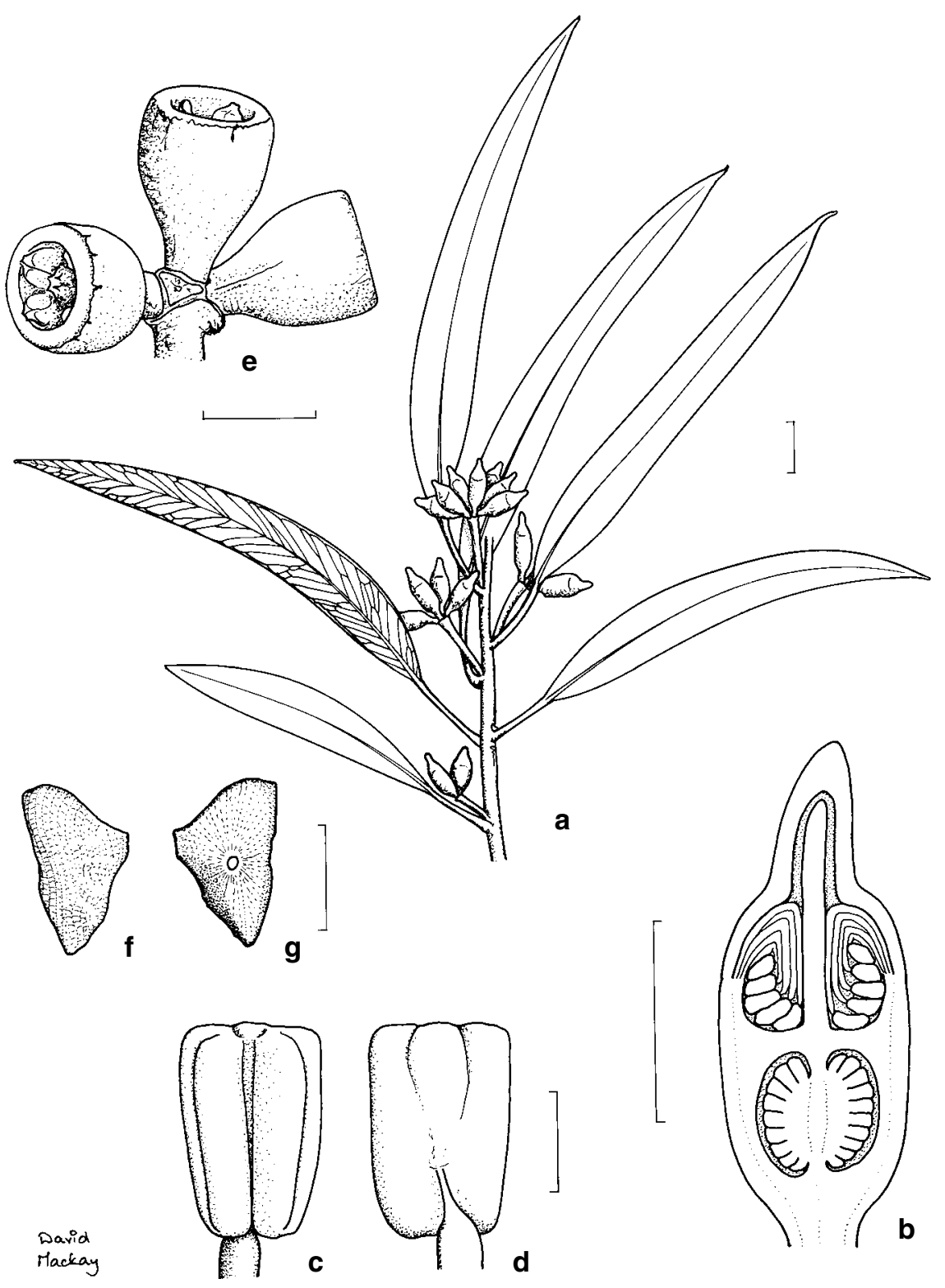

Fig. 16. E. spreta. $\mathbf{a}$, adult leaves, inflorescence and buds; $\mathbf{b}$, longitudinal section of bud; $\mathbf{c}, \mathbf{d}$, anther; e, inflorescence and fruits; $\mathbf{f}$, $\mathbf{g}$, seed (from Brooker 8839). Scale bars: $a=1 \mathrm{~cm} ; b, e=5 \mathrm{~mm} ; c, d=0.5 \mathrm{~mm}$; $\mathrm{f}, \mathrm{g}=1 \mathrm{~mm}$. 
1-2 km west of Kumarl on Peak Charles road, Brooker 8906, 7 Apr 1985 (CANB, NSW); 14.4 miles [22.8 km] NNW of Salmon Gums, Chippendale 172, 13 Mar 1967 (CANB, NSW); $71 \mathrm{~km}$ from Balladonia Motel along Eyre Highway towards Norseman, Crisp 5646, 2 Feb 1979 (CANB, AD, NSW, PERTH); $11.7 \mathrm{~km}$ south of Balladonia roadhouse on track to Mount Ragged, Hill $234 \mathcal{E}$ Johnson, 20 Oct 1983 (NSW); $66.5 \mathrm{~km} \mathrm{~N}$ of Esperance on rd to Norseman, Hill 298, Johnson E Blaxell, 22 Oct 1983 (NSW, CANB, PERTH); $60 \mathrm{~km}$ E of Norseman on Highway 1, Hill 692 \& Blaxell, 14 Nov 1983 (NSW, CANB, PERTH); 22.9 km W of Balladonia roadhouse on highway, Hill $2194 \mathcal{E}$ Johnson, 4 Nov 1986 (NSW, CANB, MEL, PERTH); $54.5 \mathrm{~km} \mathrm{~W}$ of Balladonia roadhouse on highway, Hill 2207 $\mathcal{E}$ Johnson, 4 Nov 1986 (NSW, CANB, MEL, PERTH); 10.7 km north of Salmon Gums on Norseman to Esperance highway, Hill 2240, Johnson, Brooker \& Blaxell, 5 Nov 1986 (NSW, CANB, MEL, PERTH); $14 \mathrm{~km}$ north of Rollonds road on Fields road, Hill 2312, Johnson, Blaxell \& Brooker, 7 Nov 1986 (NSW, CANB, MEL, PERTH); Dowak (N of Salmon Gums), Johnson W 189, 18 Dec 1960 (NSW); $65.8 \mathrm{~km} \mathrm{~S}$ of Balladonia towards Israelite Bay, Pryor 172 \& J. Briggs, 25 Oct 1978 (CANB, NSW).

14. Eucalyptus fraseri (Brooker) Brooker, Australian Forest Res. 7: 65 (1976).

Basionym: Eucalyptus conglobata (R. Br. ex Benth.) Maiden subsp. fraseri Brooker, Nuytsia, 1: 251 (1972).

Type: Western Australia: 14 miles west of Balladonia, M.I.H. Brooker 2472, 14 Feb 1970 (holo PERTH; iso PERTH, AD, GAUBA, BRI, CANB, K, MEL, NSW).

Tree to $25 \mathrm{~m}$ tall. Bark smooth, white with brown or bronze stripes, shedding in long ribbons (with a persistent 'stocking' in subsp. melanobasis). Juvenile leaves disjunct, petiolate, ovate to orbiculate, glaucous, to $15 \mathrm{~cm}$ long, $10 \mathrm{~cm}$ wide Adult leaves disjunct, lanceolate to broad lanceolate, acute, glossy, dark green, coriaceous, $10.0-25.0 \mathrm{~cm}$ long, $1.5-4.0 \mathrm{~cm}$ wide; petioles \pm flattened or quadrangular, \pm decurrent into 4 -angled young stems, $1.5-4.0 \mathrm{~cm}$ long; lateral veins at $20-30^{\circ}$ to midrib, moderately closely spaced, \pm degenerate; intramarginal vein present, indistinct, c. $1.0 \mathrm{~mm}$ from margin. Umbellasters axillary, 7-flowered. Peduncles thick, angular, 2-12 mm long. Buds and fruits sessile, rarely shortly pedicellate with thick pedicels up to $3 \mathrm{~mm}$ long. Mature

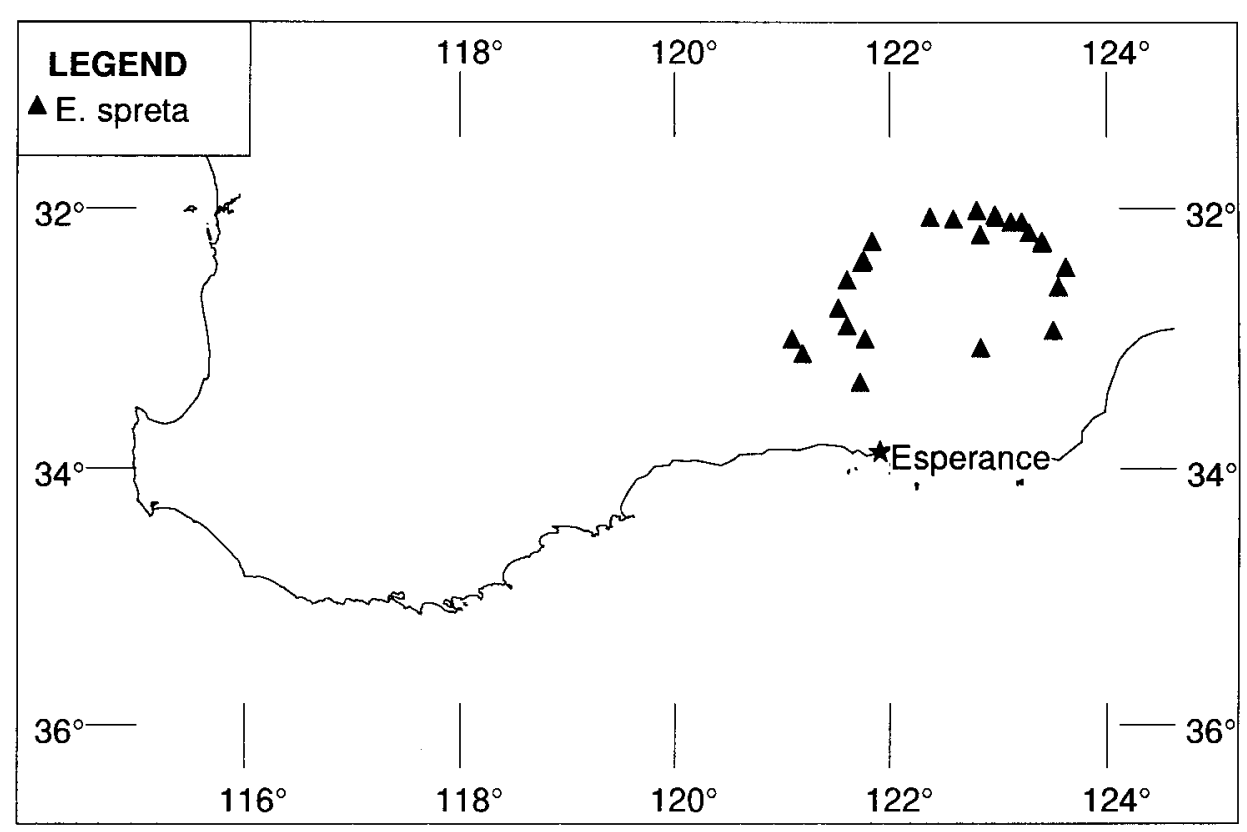

Fig. 17. Distribution of E. spreta. 


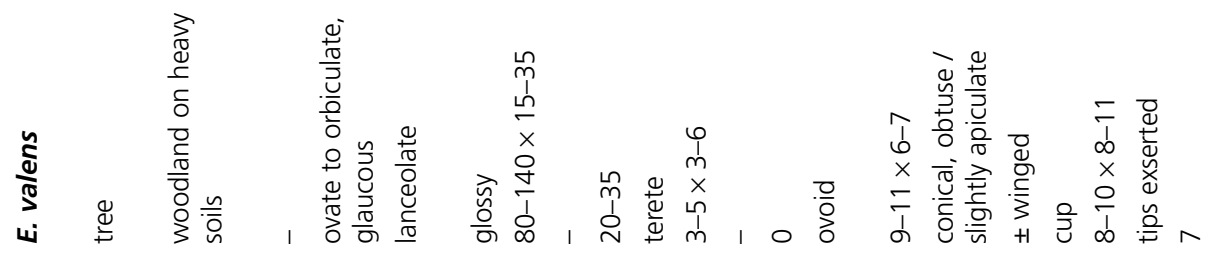

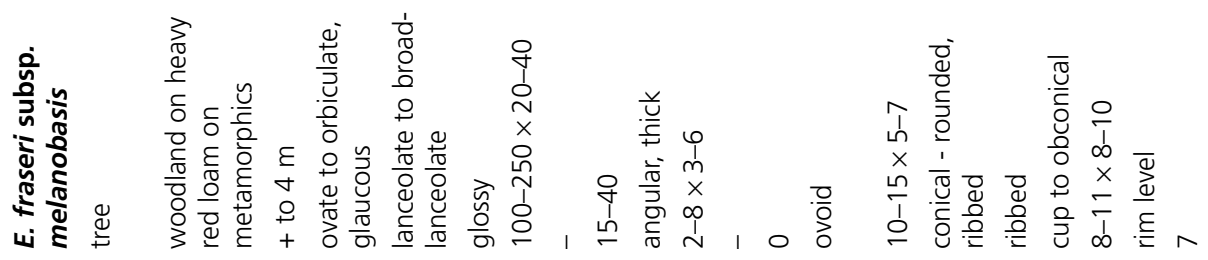

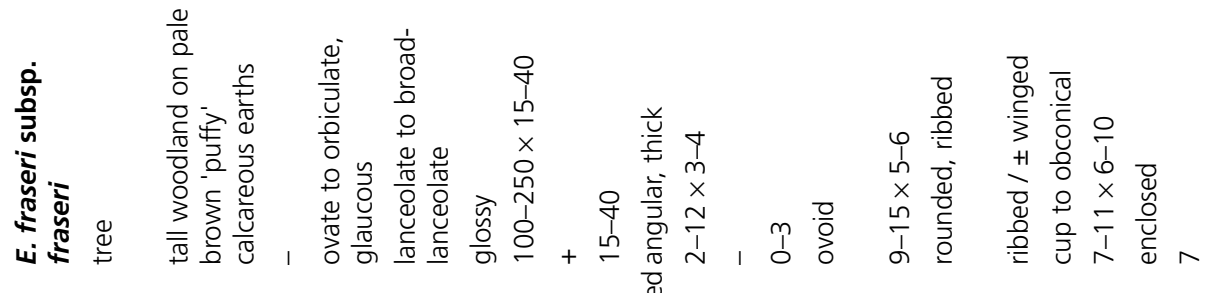

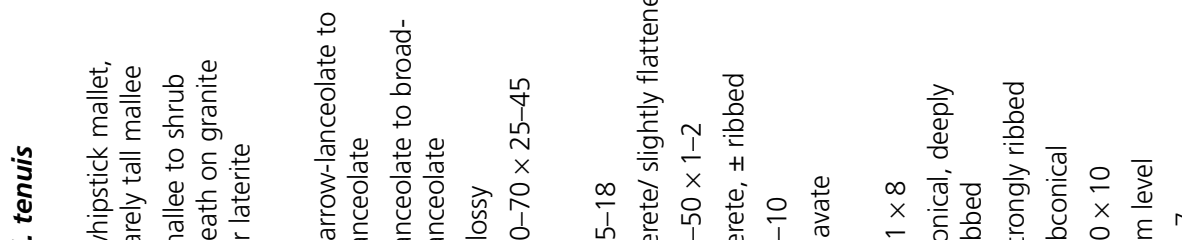

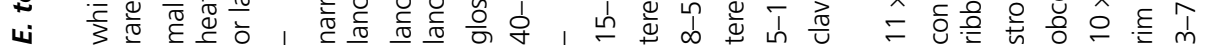

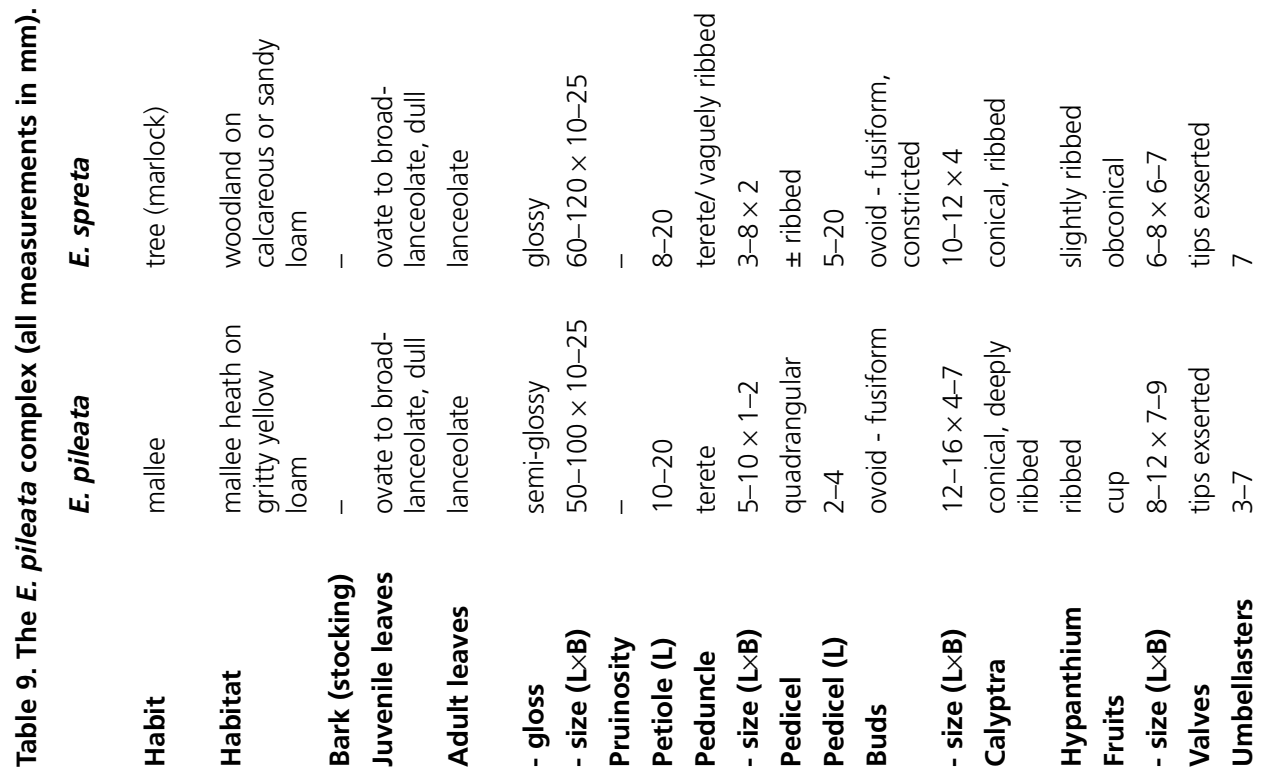


buds ovoid, 9-15 mm long, 5-6 mm diam.; calyptra \pm cup-shaped, rounded, often with a pronounced median constriction, ribbed, \pm as long as hypanthium or slightly shorter. Fruits cup-shaped or obconical, slightly constricted apically, 4-locular, 7-11 mm long, 6-10 mm diam.; calyptra scar and stemonophore flat or somewhat raised, c. $1.0 \mathrm{~mm}$ wide; disc depressed at c. $45^{\circ}, 1.0-1.5 \mathrm{~mm}$ wide; valves broadly triangular, enclosed, raised at c. $45^{\circ}$. Seeds irregular, flattened, shallowly reticulate, glossy deep red-brown, c. $2.0 \mathrm{~mm}$ long; hilum ventral. Chaff similar, angular, smaller.

Two subspecies are recognised, as follows (see also Table 9).

14A. Eucalyptus fraseri (Brooker) Brooker subsp. fraseri

Tree to $15 \mathrm{~m}$ tall. Bark smooth throughout. Adult leaves 9-14 cm long, 1.5-3.0 cm wide; petioles $1.5-3.5 \mathrm{~cm}$ long. Umbellasters axillary, 7-flowered. Peduncles 5-13 mm long. Buds and fruits sessile or shortly pedicellate. Mature buds ovoid, 9-13 mm long, 5-6 mm diam. Fruits 7-9 mm long, 6-9 mm diam.

Locally frequent but sporadic, in tall woodland on pale brown 'puffy' calcareous earths from east of the Fraser Range to east of Balladonia, and somewhat north of there (Fig. 18).

Conservation status: not considered to be at risk.

Selected specimens (from 20 examined): Western Australia: $5 \mathrm{~km}$ west of Balladonia [roadhouse], Boomsma 359, 28 July 1978 (AD, NSW); 9 miles [14.4 km] N of Tower Hill corner on road to Balladonia, Brooker B 4532, 10 Apr 1974 (CANB, NSW); 8.3 km S of Balladonia towards Mt Ragged, Brooker 5627, 3 Apr 1977 (CANB, AD, MEL, NSW, PERTH); 156 km W of Cocklebiddy, Brooker 5624, 2 Apr 1977 (CANB, AD, MEL, NSW, PERTH); Cape Arid National Park, 16 km S of Juranda Rock Hole along road to Mt Ragged (Tower Peak), Crisp 4800, 5 Jan 1979 (CANB, NSW, PERTH); 102 km west of Caiguna on Highway 1, Hill 204 E Johnson, 19 Oct 1983 (NSW, CANB, PERTH); 81 km E of Balladonia roadhouse on Highway 1, Hill 2180 \& Johnson, 3 Nov 1986 (NSW, CANB, MEL, PERTH); $16.9 \mathrm{~km} \mathrm{~W}$ of Balladonia roadhouse on Highway 1, Hill 2189 \& Johnson, 4 Nov 1986 (NSW, CANB, MEL, PERTH); $50.3 \mathrm{~km} \mathrm{~W}$ of Balladonia roadhouse on Highway 1, Hill $2204 \mathcal{E}$ Johnson, 4 Nov 1986 (NSW, PERTH, CANB, MEL, CANB); $30.7 \mathrm{~km} \mathrm{~N}$ of Israelite Bay turnoff at Mt Ragged on track to Balladonia, Hill 3172, 9 Sep 1988 (NSW, CANB, PERTH).

Intergrades: E. fraseri subsp. fraseri $\leftrightarrow$ E. spreta

Specimens examined: Western Australia: Coragina Rock, Beard 5283, 27 Oct 1967 (KPBG, NSW); Pine Hill, Beard 6405, 18 Sep 1970 (KPBG, NSW).

14B. Eucalyptus fraseri (Brooker) Brooker subsp. melanobasis L.A.S. Johnson E K.D. Hill, subsp. nov.

A subsp. fraseri distinguitur: fructus majores, sessiles in pedunculis brevioribus; calyptra constricta, folia majora coriaceque, et cortex basaliter asper induratusque.

Type: Western Australia: Fraser Range, $87.7 \mathrm{~km}$ W of Balladonia Roadhouse on Highway 1 (3201'S 17249'E), K.D. Hill 701 E D.F. Blaxell, 14 Nov 1983 (holo NSW; iso CANB, K, PERTH)

[E. fraseri subsp. 'blackbutt', Brooker and Kleinig (1990: 325)]

Tree to $15 \mathrm{~m}$ tall. Bark smooth, with a persistent thick hard black basal 'stocking' for 1.5-4 m. Adult leaves $10.0-25.0 \mathrm{~cm}$ long, $2.0-4.0 \mathrm{~cm}$ wide; petioles $1.5-4.0 \mathrm{~cm}$ long. Umbellasters axillary, 7-flowered. Peduncles 2-8 mm long. Buds and fruits sessile. Mature buds ovoid, c. $15 \mathrm{~mm}$ long, c. $6 \mathrm{~mm}$ diam. Fruits 8-11 mm long, 8-10 mm diam (Fig. 19). 
Subsp. melanobasis is distinguished from subsp. fraseri by the larger, sessile fruits on shorter peduncles, the constricted calyptra, the larger, leathery leaves and the distinctive stocking of hard, rough black bark.

Distributed for a few kilometres along Highway One on the eastern slopes and crest of the Fraser Range, and probably extending north and south along the range (Fig. 18). This distribution lies to the west of that of subsp. fraseri, and also appears to be restricted to outcrops of basic metamorphic rocks.

This taxon is locally dominant on calcareous red loam over basic metamorphic rocks, usually in association with E. optima L.A.S. Johnson \& K.D. Hill and E. laevis.

Conservation status: restricted to a small area, although not at risk within this area (2R).

The epithet is from the Greek melas, melanos, dark, and basis, base, in reference to the characteristic stocking of black persistent bark.

Selected specimens (from 6 examined): Western Australia: $83 \mathrm{~km} \mathrm{~W}$ of Balladonia, Brooker 7487, 28 Apr 1982 (CANB, NSW); 67.4 miles [108.5 km] E of Norseman, Chippendale 158, 12 Mar 1967 (CANB, NSW); Fraser Range, $84 \mathrm{~km}$ west of Balladonia roadhouse on Highway 1, Hill $230 \mathcal{E}$ Johnson, 19 Oct 1983 (NSW).

15. Eucalyptus valens L.A.S. Johnson $\mathcal{E}$ K.D. Hill, sp. nov.

$\mathrm{Ab}$ E. fraseri distinguitur: fructus et alabastra sessiles in pedunculis brevioribus crassioribus.

Type: Western Australia: $1 \mathrm{~km} \mathrm{~W}$ of Norseman to Esperance road on Lake King Road (32¹2'S, 1214'ㄹ), M.I.H. Brooker 5658, 5 Apr 1977 (holo NSW; iso AD, CANB, MEL, PERTH).

[E. species T, Brooker \& Kleinig 1990: 323 (1990)]

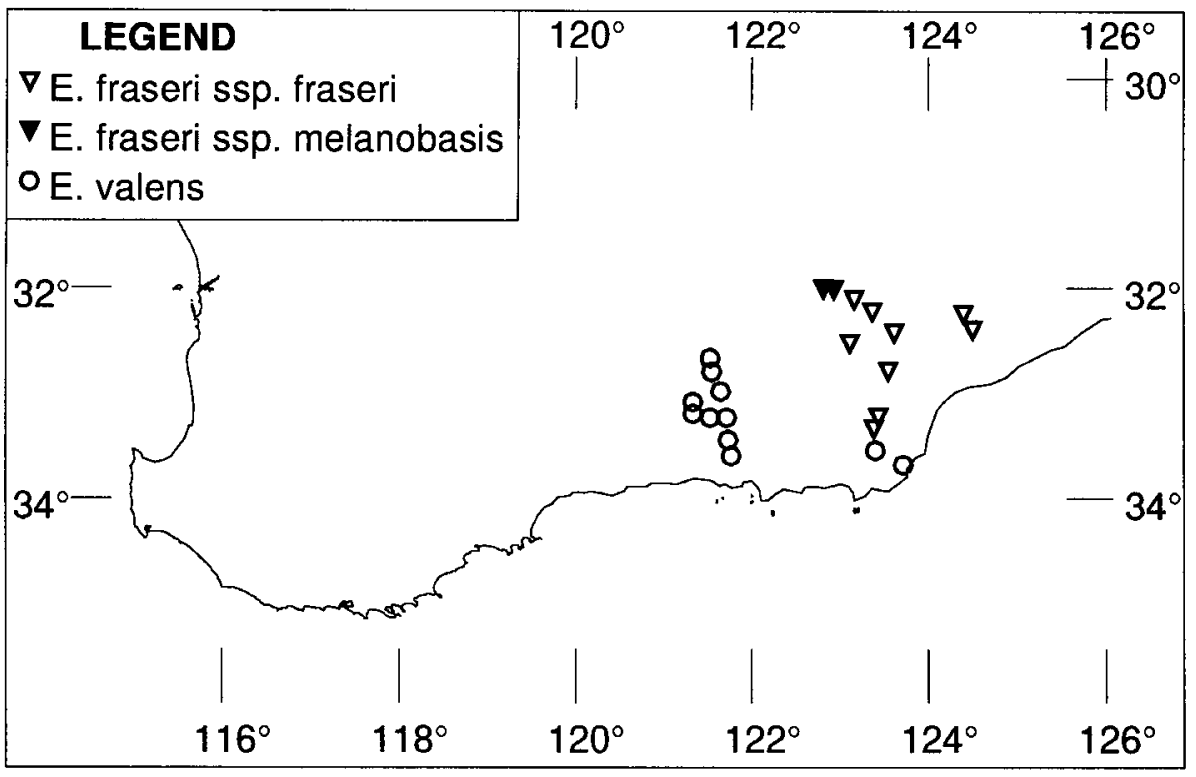

Fig. 18. Distribution of E. fraseri subsp. fraseri, E. fraseri subsp. melanobasis, E. valens. 
Tree to $10 \mathrm{~m}$ tall, characteristically with a long, straight bole. Bark smooth, white to base, shedding in long ribbons. Juvenile leaves ovate to orbiculate, glaucous. Adult leaves disjunct, lanceolate, acuminate, glossy, coriaceous, $8.0-14.0 \mathrm{~cm}$ long, $1.5-3.5 \mathrm{~cm}$ wide. Petioles flattened, $2.0-3.5 \mathrm{~cm}$ long. Young stems 4 -angled. Lateral veins at c. $30-45^{\circ}$ to midrib, moderately spaced, somewhat degenerate, intramarginal vein present, \pm indistinct, $1.0-2.0 \mathrm{~mm}$ from margin, Umbellasters axillary, 7-flowered. Peduncles 3-5 mm long, 3-6 mm diam. Buds and fruits sessile. Mature buds ovoid,
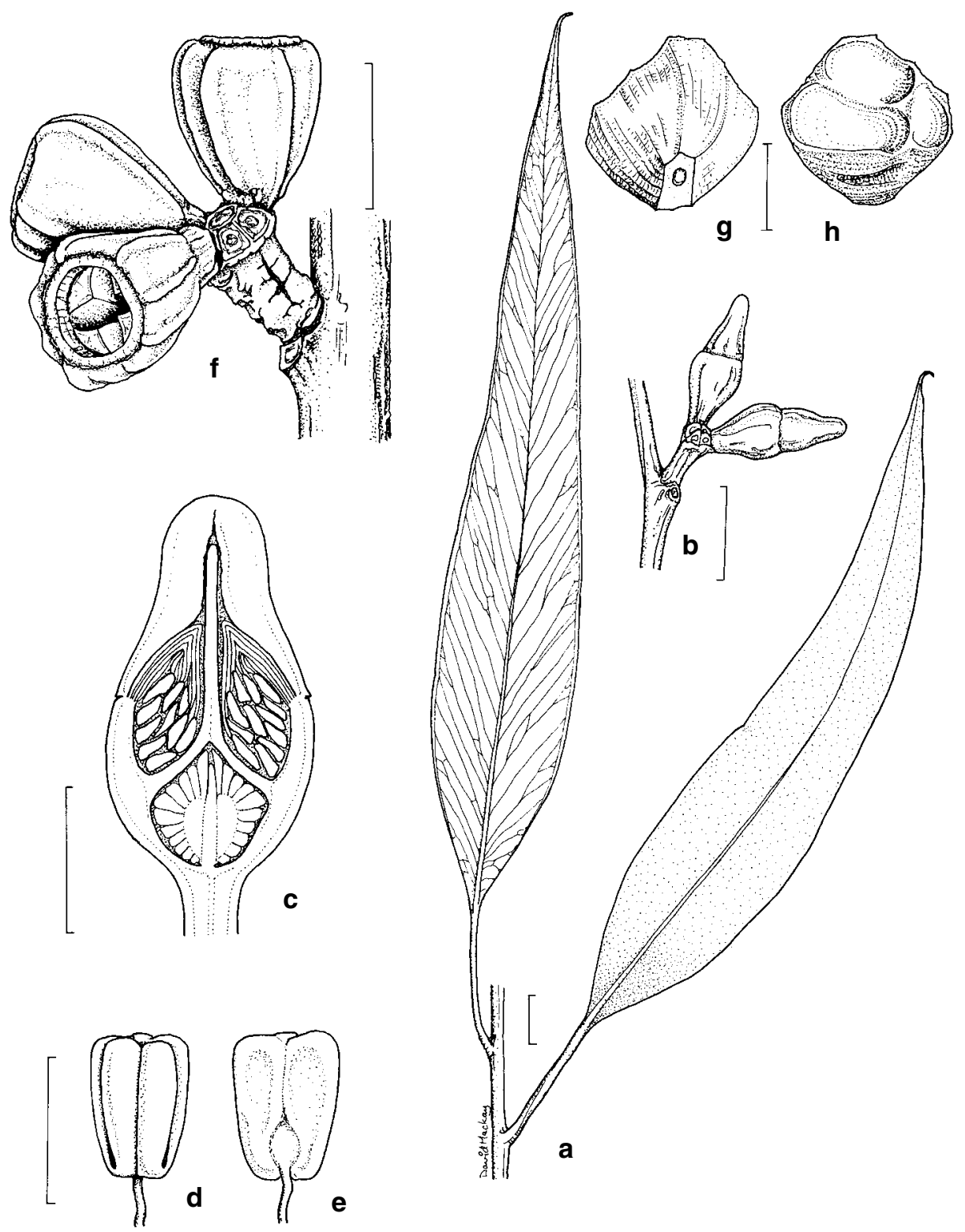

Fig. 19. E. fraseri subsp. melanobasis. $\mathbf{a}$, adult leaves; $\mathbf{b}$, inflorescence and buds; $\mathbf{c}$, longitudinal section of bud; $\mathbf{d}, \mathbf{e}$, anther; $\mathbf{f}$, inflorescence and fruits; $\mathbf{g}$, $\mathbf{h}$, seed (from Hill 230). Scale bars: $a, b, f=1 \mathrm{~cm}$; $c=5 \mathrm{~mm} ; \mathrm{d}, \mathrm{e}, \mathrm{g}, \mathrm{h}=1 \mathrm{~mm}$. 
0.9-1.1 cm long, 0.6-0.7 cm in diameter. Calyptra conical, strongly convex, obtuse, slightly shorter than hypanthium. Fruits cup shaped, 4-5-locular, often \pm 2 -winged, 0.8-1.0 cm long, 0.8-1.1 cm diam. Calyptra scar and stemonophore raised, sometimes vertically, c. $1 \mathrm{~mm}$ wide. Disc depressed, from near horizontal to near vertical. Valves broadly triangular, enclosed, tips rim-level or slightly exserted, incurved. Seeds irregular, flattened, shallowly reticulate, glossy deep red-brown, c. $2.0 \mathrm{~mm}$ long; hilum ventral. Chaff similar, angular, smaller (Fig. 20).

$E$. valens differs from $E$. fraseri in the sessile, usually shorter buds and fruits and the shorter; thicker peduncles (see also Table 9).

Distributed through the wheat belt areas north of Esperance, away from the coast (Fig. 18).

A woodland species of heavier, 'harder' soils, often associated with E. longicornis (F. Muell.) F. Muell. ex Maiden, E. transcontinentalis Maiden, E. flocktoniae and to a lesser extent many other southern woodland species.

Conservation status: not considered to be at risk.

The epithet is from the Latin valens, strong or vigorous, referring to the robust tree habit.

Selected specimens (from 25 examined): Western Australia: 10 miles [16 km] SW of Mt Ragged, Beard 6401, 18 Sep 1970 (KPBG, NSW); between 26 and 58 miles [42-92.4 km] south of Norseman towards Esperance, Brooker 2495, 15 Feb 1970 (PERTH, NSW); ca. 6 miles [9.6 km] east of Scaddan, Brooker 2772, 8 Aug 1970 (PERTH, NSW); 1 km W of Norseman to Esperance road on Lake King road, Brooker 5658, 5 Apr 1977 (CANB, AD, MEL, NSW, PERTH); between Bishops road and Lort River on Belgian road, Brooker 7125, 12 Nov 1981 (CANB, NSW, PERTH); 2 km E of Lort Road on Rollonds road, Brooker 7126, 12 Nov 1981 (CANB, NSW, PERTH); $1.5 \mathrm{~km}$ from Israelite Bay track on Mt Ragged track, Brooker 8910, 8 Apr 1985 (CANB, NSW); 14.4 miles [23 km] NNW of Salmon

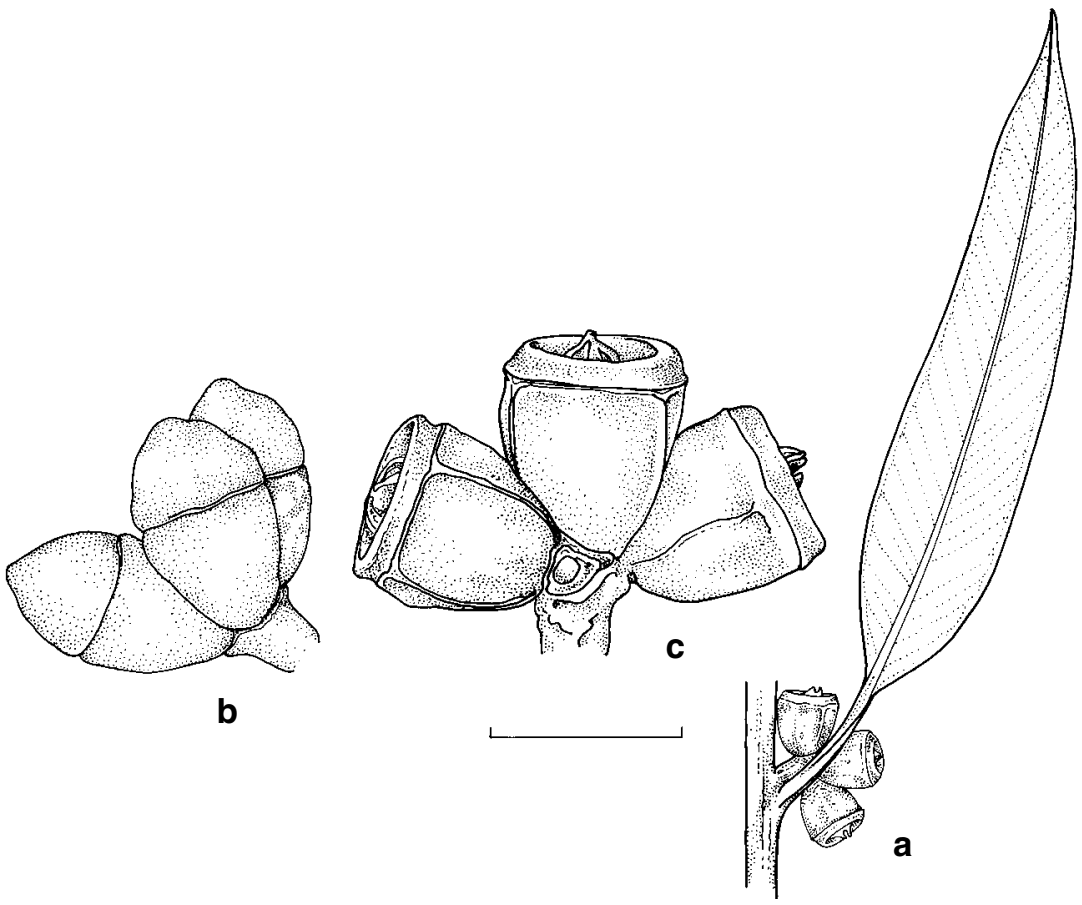

Fig. 20. E. valens. a, adult leaf, inflorescence and fruits; $\mathbf{b}$, inflorescence and buds; $\mathbf{c}$, inflorescence and fruits. (from Hill 2246). Scale bar $=1 \mathrm{~cm}$. 
Gums, Chippendale 171, 13 Mar 1967 (CANB, NSW); ca. 50 km north of Esperance, Diels 5448, 5 Nov 1901 (B, NSW); Grasspatch, Gardner 2220, 23 May 1924 (PERTH, NSW); 2 miles [3.2 km] southward from Beete, Gardner 11161, 7 Nov 1953 (PERTH, NSW); 16 km west of Grasspatch on Grasspatch road, Hill 299, Johnson \& Blaxell, 22 Oct 1983 (NSW, CANB); 19 km south of Salmon Gums on Norseman to Esperance road, Hill 2246, Johnson, Brooker \& Blaxell, 5 Nov 1986 (NSW, CANB, MEL, PERTH); 5 miles [8 km] S of Salmon Gums, Johnson W 191, 18 Dec 1960 (NSW).

\section{The Eucalyptus obtusiflora complex}

Four species in Western Australia and South Australia, including E. repullans Nicolle and E. gypsophila Nicolle, which we would place here rather than near E. striaticalyx W.V. Fitzg. on the basis of the mallee habit and similarities in bark and fruit morphology. See Table 10 for species included and their identification.

\section{Eucalyptus obtusiflora DC., Prodr. 3: 220 (1828).}

Type: cited as 'in Nova-Hollandia ad oram orientalem.' The corresponding specimen held in G-DC (Port Jackson, F.W. Sieber 473, 1823) is not the same as replicates of Sieber 473 held elsewhere, which represents the eastern Australian species (of section Renantheria) since described as E. obstans L.A.S. Johnson \& K.D. Hill. The specimen held in $G$ represents the Western Australian species discussed here; the 'replicates' can only be the result of the mixing of specimens.

Mallee, sometimes a small tree, to $10 \mathrm{~m}$ tall. Bark persistent on lower trunk, grey, shortly fibrous-flaky, smooth above, or smooth to base, white or greyish, shed in long, brown ribbons. Twigs, buds and fruits sometimes glaucous. Juvenile leaves disjunct, ovate to orbiculate, petiolate, glaucous, to $7 \mathrm{~cm}$ long, $5 \mathrm{~cm}$ wide. Adult leaves disjunct, narrow- to broad-lanceolate, acuminate, \pm falcate, dull, mid-green to grey-green or glaucous $5.0-14.0 \mathrm{~cm}$ long, $1.2-3.0 \mathrm{~cm}$ wide; petioles terete or slightly flattened, $1.0-2.5 \mathrm{~cm}$ long. Lateral veins indistinct, at c. $30^{\circ}$ to midrib, moderately spaced; intramarginal vein indistinct, $0.5-1.0 \mathrm{~mm}$ from margin. Umbellasters axillary, 7-11-flowered. Peduncles terete or angular, 5-20 mm long. Pedicels terete or angular, 1-15 mm long. Mature buds ovoid, 10-20 mm long, 5-8 mm diam.; calyptra hemispherical to broadly conical, striate, $1 / 2$ as long as hypanthium, distinctly narrower than hypanthium at join. Fruits cylindrical to obconical, not ribbed, 4-5-locular, 8-15 mm long, 5-12 mm diam. Calyptra scar and stemonophore c. $1 \mathrm{~mm}$ wide, raised at c. $45^{\circ}$. Disc steeply depressed, 1.5-2.0 mm wide. Valves broadly triangular, obtuse, enclosed. Seeds irregular, flattened, shallowly reticulate, glossy deep red brown, 2-2.5 mm long; hilum ventral; chaff similar, angular, smaller.

Distributed from Shark Bay to Yorkrakine Hill. Subcoastal in the north of the range, extending inland to the south, and entirely inland south of Enneabba (Fig. 21).

Three geographically separated subspecies are recognised (see Table 10 for identification).

\section{A. Eucalyptus obtusiflora DC. subsp. obtusiflora}

Mallee, usually with a short persistent stocking of fibrous bark. Buds and fruits non-glaucous. Peduncles slender. Buds and fruits slender. Calyptra rounded (Fig. 22a, b, c).

Distributed from Shark Bay to Watheroo, in coastal regions to the north but extending inland to the east of subsp. dongarraensis in the south (Fig. 21).

Locally frequent but sporadic, on red sandy soils.

Conservation status: not at risk.

Selected specimens (from 24 examined): Western Australia: 10 miles [16 km] N of Murchison River on NE Coastal Highway, Beard 6738, 7 Oct 1973 (PERTH, NSW); 30 miles [48.3 km] E of Binnu, Beard 6871, 19 Oct 1973 (PERTH, NSW); 25 miles [40.3 km] N and W of Yuna, Beard 6869, 10 Oct 1973 
(PERTH, NSW); 11.5 km NNW of Coburn Station, Brooker 5010 \& Blaxell, 8 Oct 1975 (CANB, NSW); $23 \mathrm{~km}$ NW of Strawberry on Burma Road, Brooker 7947, 26 Jan 1983 (CANB, NSW); Madden road NE of Gutha, Brooker 8655, 1 Sep 1984 (CANB, NSW); 5 km E of Highway 1 along State Barrier Fence, NE of Binnu, Brooker 8724, 31 Oct 1984 (CANB, NSW); breakaway SSE of Mount Horner, N of Pincher's road, Brooker 8816, 4 Feb 1985 (CANB, NSW); corner of Kalbarri on highway, Brooker 9464, 8 Oct 1986 (CANB, NSW); $19.3 \mathrm{~km}$ W of Denham road on Useless Loop road, Brooker 9469 , 8 Oct 1986 (CANB, NSW); 15.3 miles [24.6 km] SW of Mullewa, Chippendale 47, 20 Oct 1966 (CANB, NSW); White Peak, pr. Champion Bay, Diels 3226, 28 June 1901 (NSW); 3.9 km SE of Peter rd on Yuna rd, Hill 2943, 28 Aug 1988 (NSW); c. 4 miles [6.4 km] N of Watheroo, Johnson W 20, 10 Dec 1960 (NSW); 19.5 km south west of Denham Road on Useless Loop Road, Johnson 9379 \& B. Briggs, 10 Aug 1991 (NSW, PERTH); 11.6 miles [c. 18.5 km] N of Murchison R Crossing on NW Coastal Highway, Tindale 2726, 21 Aug 1973 (NSW, PERTH).

Hybrids: E. arachnaea subsp. arachnaea $\times$ E. obtusiflora subsp. obtusiflora

Selected specimens (from 3 examined): Western Australia: c. $15 \mathrm{~km}$ from Three Springs on Eneabba road, Hill 2558, Johnson, Brooker \& Blaxell, 21 Nov 1986 (NSW, PERTH).

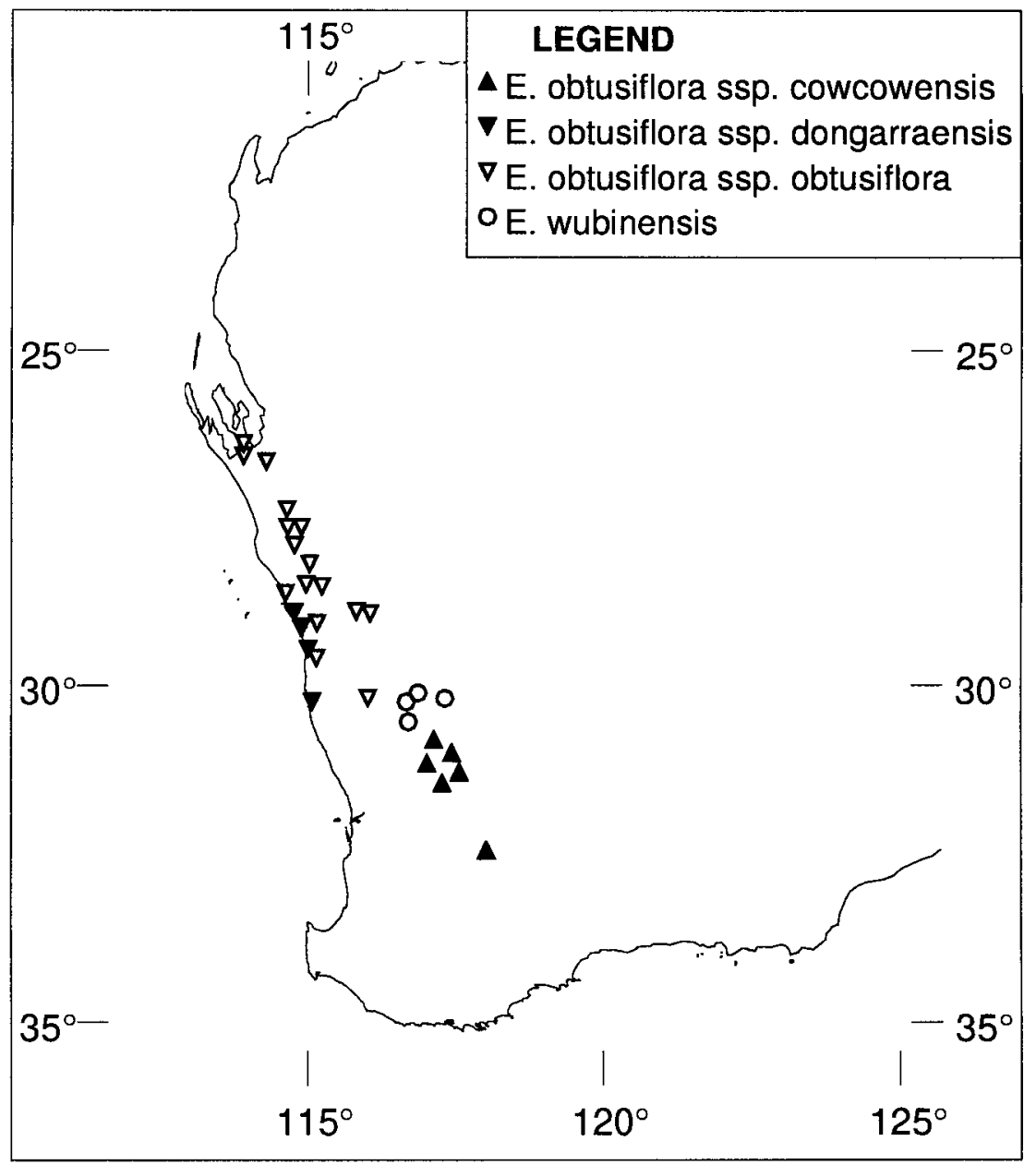

Fig. 21. Distribution of E. obtusiflora subspp. cowcowensis, dongarraensis, obtusiflora, E. wubinensis. 


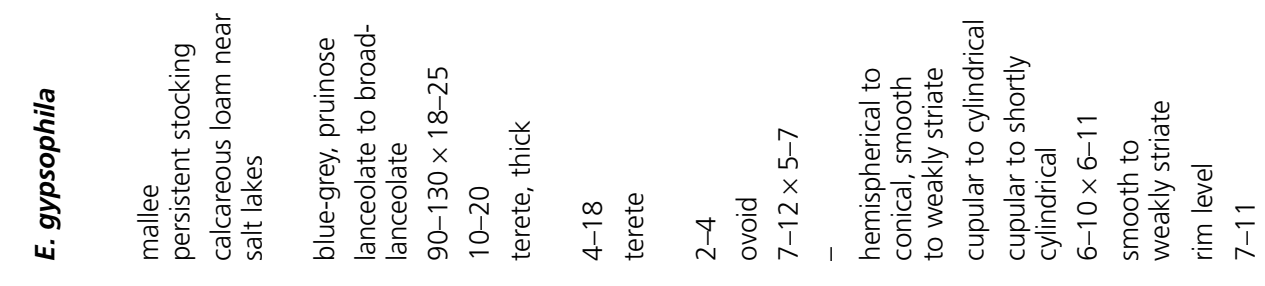

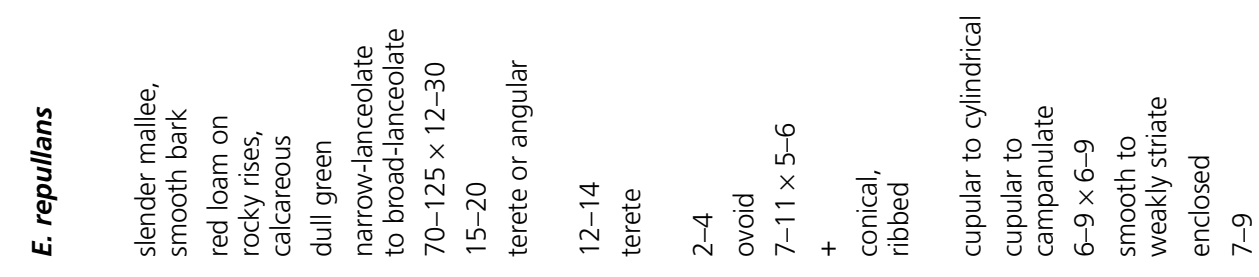

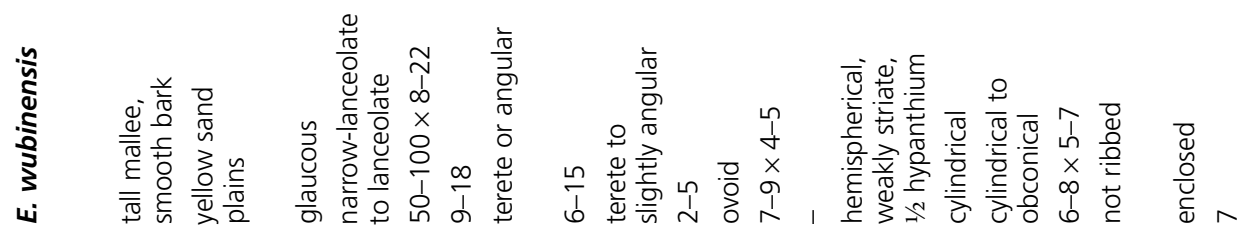

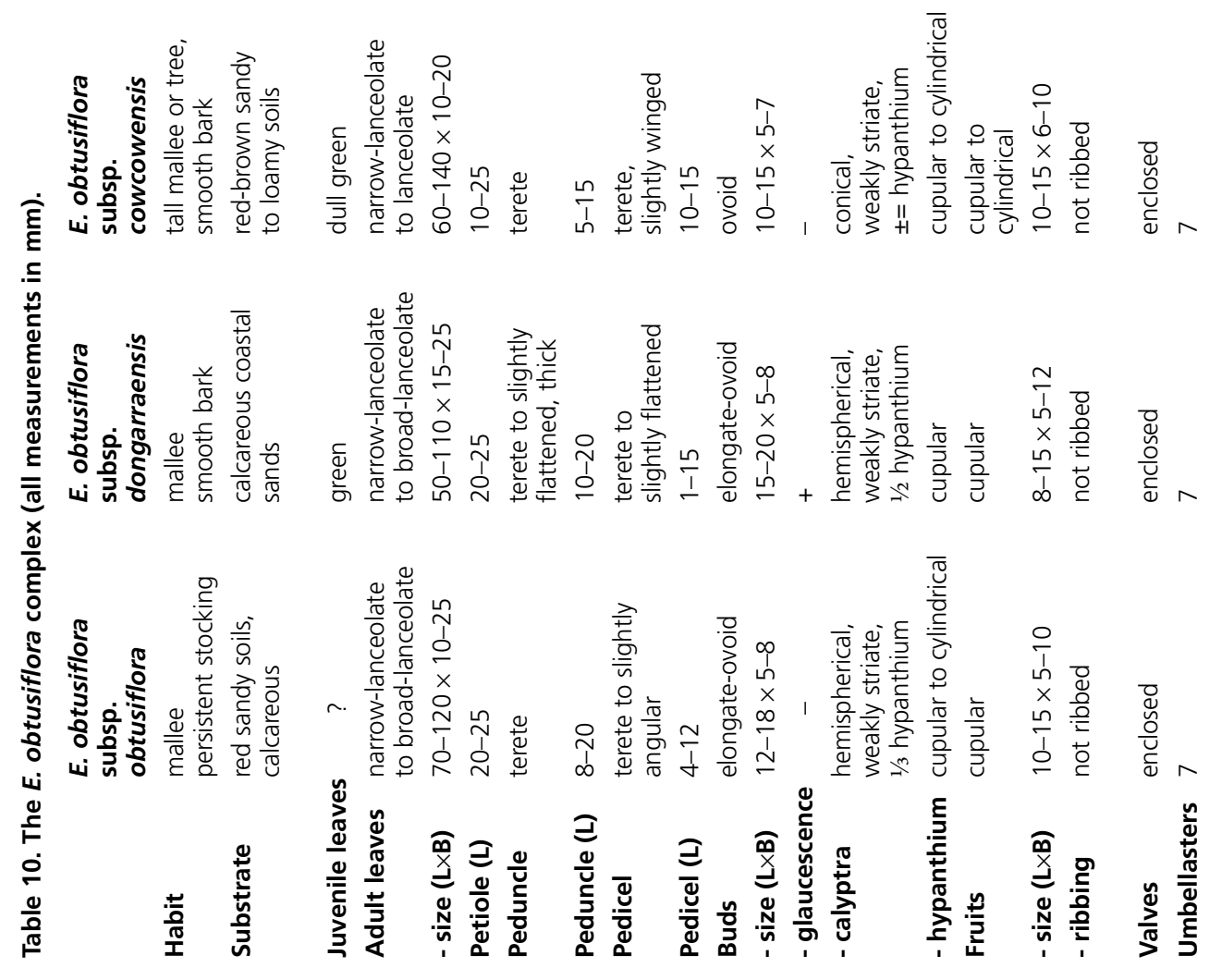


16B. Eucalyptus obtusiflora DC. subsp. dongarraensis (Maiden E Blakely) L.A.S. Johnson \& K.D. Hill, comb. et stat. nov.

Basionym: Eucalyptus dongarraensis Maiden \& Blakely, J. \& Proc. Roy. Soc. New South Wales 59: 184 (1925).

Type: Western Australia: Dongarra, J.H. Maiden, Oct 1909 (holo NSW; iso CANB, K, MEL, PERTH - 2 sheets).

Mallee. Bark smooth. Peduncles and pedicels thick. Buds and fruits broad, glaucous. Calyptra low, hemispherical (Fig. 22d, e, f).

Distributed from a short distance south of Geraldton south almost to Cliff Head (Fig. 21).

Locally frequent in dense mallee shrubland on calcareous coastal dunes.

Conservation status: not at risk.

Selected specimens (from 9 examined): Western Australia: between Georgina and Greenough, Beard 6919, 25 Oct 1973 (PERTH, NSW); Cliff Head turn-off from Highway 1, Blaxell W75/91, 7 Oct 1975 (NSW); Cliff Head road, W of Brand Highway, Brooker 8404, 23 Jan 1984 (CANB, NSW); 10 miles [16.1 km] NE from Yuna, Gardner 14263, 20 Dec 1962 (PERTH, NSW); Drovers Cave National Park, near Jurien, George 14266, 11 June 1976 (PERTH, NSW); Dongarra, Maiden s.n., Oct 1909 (NSW 42723, CANB, K, MEL, PERTH).

16C. Eucalyptus obtusiflora DC. subsp. cowcowensis L.A.S. Johnson E K.D. Hill, subsp. nov.

Inter subspecies E. obtusiflorae distinguitur: habitus 'malleeformis' vel arborescens; cortex laevis; nec alabastra nec fructus glauci; pedicelli longi graciles; alabastra angusta; calyptra conica, acuta.

Type: Western Australia: 3.3 miles [5.5 km] W. of Wyalkatchem, G.M. Chippendale 252, 9 Aug 1967 (holo NSW; iso CANB, PERTH).

Tall mallee or tree. Bark smooth. Buds and fruits not glaucous. Peduncles long and slender. Buds narrow. Calyptra conical, pointed (Fig. 22g, h, i).

Scattered and sporadic, from near Wongan Hills to Yorkrakine (Fig. 21).

Conservation status: not at risk.

The epithet is from the Cowcowing district of Western Australia, where this taxon occurs. The syllable 'ing' is deliberately omitted for brevity and euphony.

Selected specimens (from 13 examined): Western Australia: $4.3 \mathrm{~km} \mathrm{~N}$ of Dowerin on Cadoux Road, Brooker 7610, 14 Sep 1982 (CANB, NSW); 3.3 miles [5.1 km] W of Wyalkatchem, Chippendale 252, 9 Aug 1967 (CANB, NSW); 2 miles [3.2 km] S of Yorkrakine, Chippendale 335, 18 Mar 1968 (CANB, NSW); $25.3 \mathrm{~km}$ from Kondinin on Corrigin road, Hill 2479, Johnson \& Blaxell, 15 Nov 1986 (NSW, PERTH); $38.2 \mathrm{~km}$ south of Koorda on Wyalkatchem road, Hill 2921, 27 Aug 1988 (NSW, CANB, PERTH); $26.7 \mathrm{~km} \mathrm{~N}$ of Cunderdin on Wyalkatchem rd, Johnson 9114 \& Johnson, 18 May 1988 (NSW, PERTH); Cowcowing, Koch 987, Aug 1904 (NSW); Next to Ninghan location 1716, Smith 643, 13 Feb 1986 (MEL, NSW).

Intergrades: E. obtusiflora subsp. cowcowensis $\leftrightarrow$ subsp. obtusiflora

Selected specimens (from 6 examined): Western Australia: W slope of Mt O'Brien, NW of Wongan Hills, Briggs 8996, 7 Oct 1992 (NSW); track to tower, Wongan Hills, Brooker 8189, 30 June 1983 (CANB, NSW); $25 \mathrm{~km}$ from Piawaning along road to Wongan Hills town, $1 \mathrm{~km} \mathrm{~S}$ of road, Crisp 5486, 26 Jan 1979 (CANB, NSW, PERTH); Wongan Hills, N slope of Mt O'Brien on track to radio tower, Hill 2933, 27 Aug 1988 (NSW). 


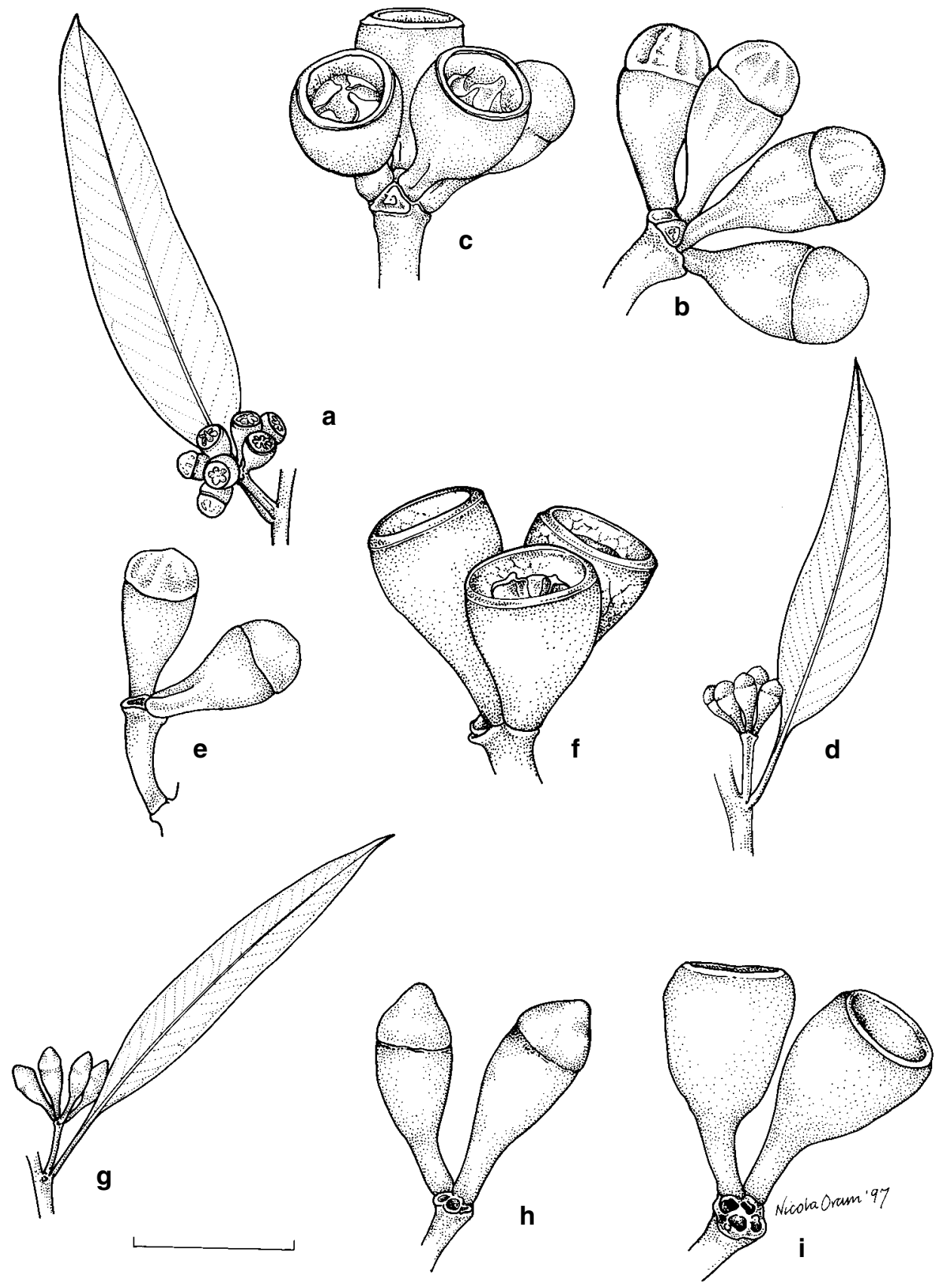

Fig. 22. E. obtusiflora subsp. obtusiflora. a, adult leaf, inflorescence and immature fruits; b, inflorescence and buds; c, inflorescence and fruits (from Johnson W20). E. obtusiflora subsp. dongarraensis. $\mathbf{d}$, adult leaf, inflorescence and buds; $\mathbf{e}$, inflorescence and buds; $\mathbf{f}$, inflorescence and fruits (from Blaxell W75/91). E. obtusiflora subsp. cowcowensis. g, adult leaf, inflorescence and buds; $\mathbf{h}$, inflorescence and buds; i, inflorescence and fruits (from Hill 2921). Scale bar $=1 \mathrm{~cm}$. 


\section{Eucalyptus wubinensis L.A.S. Johnson \& K.D. Hill, sp. nov.}

Affinis E. obtusiflora, distinguitur: habitus 'malleeformis', cortex laevis non glauca; fructus parvi (ad $7 \times 6 \mathrm{~mm}$ ) non costatae.

Type: Western Australia: $6.8 \mathrm{~km}$ E of Rabbit Proof Fence rd along Glamoff rd, SE of Wubin, Hill 378, Johnson, Blaxell \& Brooker, 26 Oct 1983 (holo NSW; iso CANB, PERTH).

Mallee to $8 \mathrm{~m}$ tall. Bark smooth to base, white or greyish with brown or bronze streaks, shedding in long ribbons. Twigs, buds and fruits not glaucous. Juvenile leaves disjunct, ovate to orbiculate, petiolate, glaucous, to $7 \mathrm{~cm}$ long, $4.5 \mathrm{~cm}$ wide. Adult leaves disjunct, narrow-lanceolate to lanceolate, acuminate, \pm falcate, dull, mid-green to grey-green, not glaucous, $5.0-10.0 \mathrm{~cm}$ long, $0.8-2.2 \mathrm{~cm}$ wide; petioles terete or slightly flattened, $0.9-1.8 \mathrm{~cm}$ long. Lateral veins distinct, at $30-40^{\circ}$ to midrib, moderately spaced; intramarginal vein distinct, $0.5-1.0 \mathrm{~mm}$ from margin. Umbellasters axillary, 7-flowered. Peduncles terete or angular, 6-15 mm long. Pedicels terete or angular, 2-5 mm long. Mature buds ovoid, 7-9 mm long, 4-5 mm diam.; calyptra hemispherical, weakly striate, $1 / 2$ as long as hypanthium, distinctly narrower than hypanthium at join. Fruits cylindrical to obconical, not ribbed, 4-5-locular, 6-8 mm long, 5-7 mm diam. Calyptra scar and stemonophore c. $1 \mathrm{~mm}$ wide, raised at c. $45^{\circ}$. Disc steeply depressed, 1.5-2.0 mm wide. Valves broadly triangular, obtuse, enclosed. Seeds irregular, flattened, shallowly reticulate, glossy deep red brown, c. $2 \mathrm{~mm}$ long; hilum ventral. Chaff similar, angular, smaller (Fig. 23).
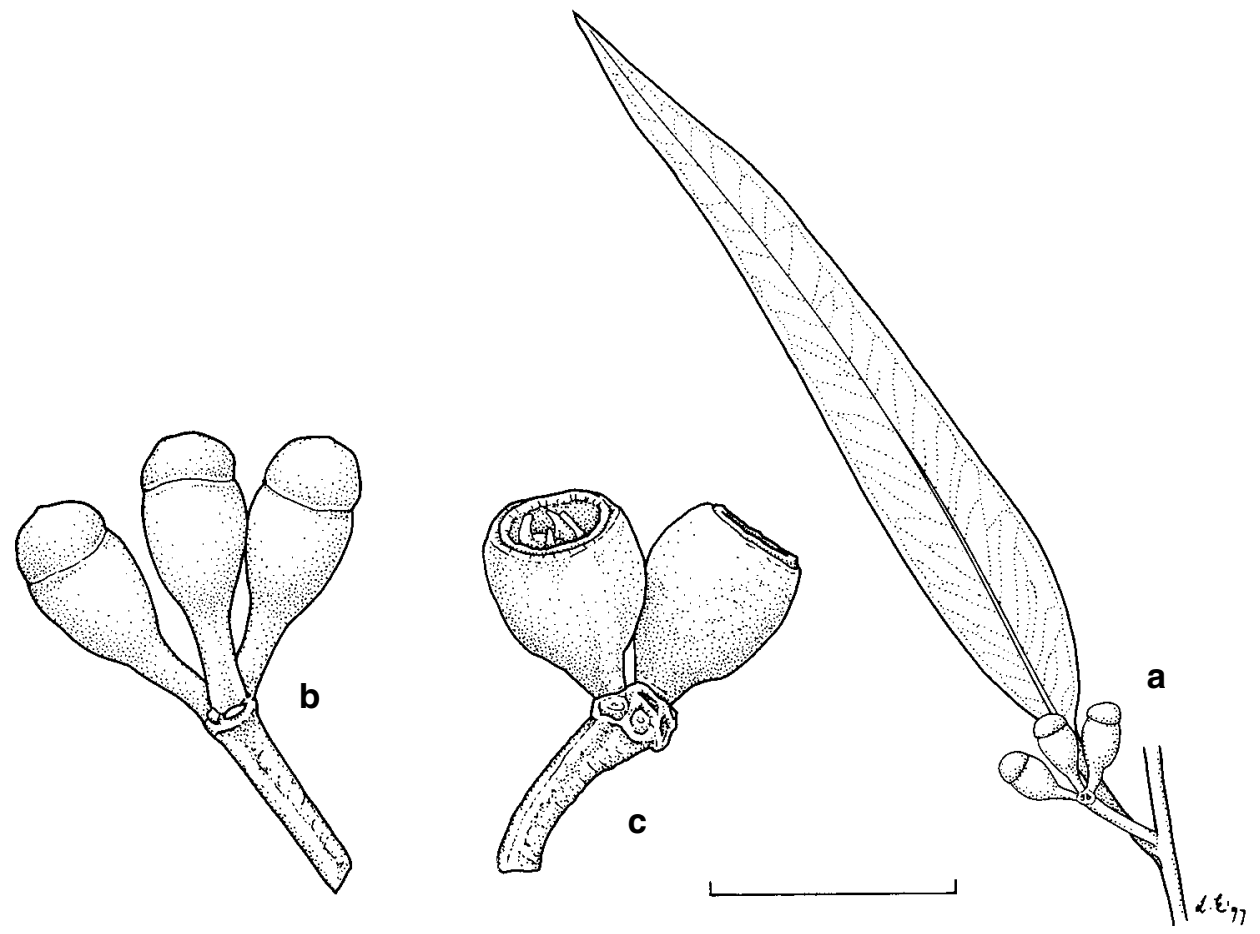

Fig. 23. E. wubinensis. a, adult leaf, inflorescence and buds; $\mathbf{b}$, inflorescence and buds. c, inflorescence and fruits. (a, b from Hill 378, c from Brooker 8303). Scale bar $=1 \mathrm{~cm}$. 
Nearest to E. obtusiflora, from which it can be distinguished by the following combination of characters: mallee; bark smooth; juvenile leaves glaucous; buds and fruits not glaucous; fruits small (to $8 \times 7 \mathrm{~mm}$ ), not ribbed (see also Table 10). Although various of these character states are shared with the subspecies of E. obtusiflora in different combinations, it is the combination of characters that distinguishes this taxon.

Distributed over a restricted area from east of Wubin to Ballidu, east to Kulja (Fig. 21).

Locally frequent in mallee shrubland on yellow sandplain country. Often associated with E. plenissima (C. Gardner) Brooker and E. dolichocera L.A.S. Johnson \& K.D. Hill, although about 15 other eucalypt species have been recorded as associates.

Conservation status: not at risk.

The epithet is from the occurrence in the Wubin district.

Selected specimens (from 10 examined): Western Australia: between Damboring and Ballidu, at rail crossing, $8.6 \mathrm{~km} \mathrm{~N}$ of Ballidu, Brooker 7923, 12 Jan 1983 (CANB, NSW); $6.6 \mathrm{~km}$ E of old rabbit proof fence on Glamoff road, E of Wubin, Brooker 8302, 25 Oct 1983 (CANB, NSW); on old rabbit proof fence, south of Glamoff road, Brooker 8303, 26 Oct 1983 (CANB, NSW); $1.3 \mathrm{~km} \mathrm{~S}$ of Glamoff Road on RPF [Rabbit Proof Fence] road E of Wubin, Brooker 8429, 25 Jan 1984 (CANB, NSW); c. 3 km SE of Karrakatta [Karrakutata] hill, Brooker 8431, 25 Jan 1984 (NSW); $1.2 \mathrm{~km} \mathrm{E} \mathrm{of} \mathrm{highway} \mathrm{on}$ Goatcher rd (N of Dalwallinu), Hill 2938, 27 Aug 1988 (NSW, CANB, PERTH); Watheroo Rabbit fence, Koch 1608, Sep 1905 (NSW).

18. Eucalyptus assimilans L.A.S. Johnson $\mathcal{E}$ K.D. Hill, sp. nov.

Affinis E. sheathianae, distinguitur: folia, alabastra et fructus multum majores; pedunculi pedicellique proportione longiores.

Type: Western Australia: $20.2 \mathrm{~km}$ W. of Balladonia Roadhouse on Highway $1\left(32^{\circ} 15^{\prime} \mathrm{S}\right.$ 12326'E), K.D. Hill 218 E L.A.S. Johnson, 19 Oct 1983 (holo NSW; iso CANB, K, PERTH)

Tree to $15 \mathrm{~m}$ tall. Bark smooth to base, white or greyish, shed in long, broad pale brown ribbons. All parts glaucous. Juvenile leaves ovate to broad-lanceolate, markedly acuminate. Adult leaves disjunct, lanceolate, acuminate, \pm falcate, dull or slightly glossy, $7.0-18.0 \mathrm{~cm}$ long, $1.5-4.0 \mathrm{~cm}$ wide; petioles terete or slightly flattened, $2.0-3.3 \mathrm{~cm}$ long; lateral veins indistinct, at c. $30^{\circ}$ to midrib, moderately spaced, \pm degenerate; intramarginal vein indistinct, $0.5-1.0 \mathrm{~mm}$ from margin. Umbellasters axillary, 7-flowered. Peduncles terete or vaguely angular, 10-22 mm long. Pedicels terete or vaguely angular, 4-8 mm long. Mature buds ovoid, c. $15 \mathrm{~mm}$ long and $7 \mathrm{~mm}$ diam. (or more); calyptra conical, convex, obtuse, slightly shorter than hypanthium. Fruits obconical, 5-locular, 9-12 mm long, 8-9 mm diam.; calyptra scar and stemonophore c. $1 \mathrm{~mm}$ wide, raised at c. $45^{\circ}$; disc depressed at c. $45^{\circ}, 1.5-2.0 \mathrm{~mm}$ wide; valves broadly triangular, obtuse, enclosed. Seeds irregular, flattened, shallowly reticulate, glossy deep red brown, 2.5-3.0 mm long; hilum ventral. Chaff similar, angular, smaller (Fig. 24).

Scattered along the highway from the type locality west to around Newman's Rock (Fig. 25). The country away from the highway is poorly explored, and further exploration will probably extend the range of this species.

A sporadic woodland species on somewhat sandy calcareous loams in gently undulating country. Associated with E. optima, E. melanoxylon, E. indurata and Triodia sp.

E. assimilans differs from E. sheathiana Maiden in the much larger leaves, buds and fruits with proportionally longer peduncles and pedicels.

Conservation status: not considered to be at risk.

The epithet is from the Latin assimilans, a variant of assimulans, making like, in a sense resembling, from the species general resemblance to E. sheathiana. 
Selected specimens (from 13 examined): Western Australia: $32.1 \mathrm{~km} \mathrm{NW}$ of Balladonia towards Norseman, Brooker 8837, 10 Feb 1985 (CANB, NSW); On road between Norseman and Balladonia, Carr 1237 E Carr, 9 Sep 1969 (CANB, AD, MEL, NSW, PERTH); $20.2 \mathrm{~km} \mathrm{~W}$ of Balladonia roadhouse on Highway 1, Hill 710 \& Blaxell, 14 Nov 1983 (NSW, AD, CANB, K, MEL, PERTH); $52.5 \mathrm{~km} \mathrm{~W}$ of Balladonia roadhouse on Highway 1, Hill 2205 E Johnson, 4 Nov 1986 (NSW, CANB, MEL, PERTH); $16.9 \mathrm{~km}$ west of Balladonia roadhouse on Highway 1, Hill 2188 \& Johnson, 4 Nov 1986 (NSW, CANB, MEL, PERTH).

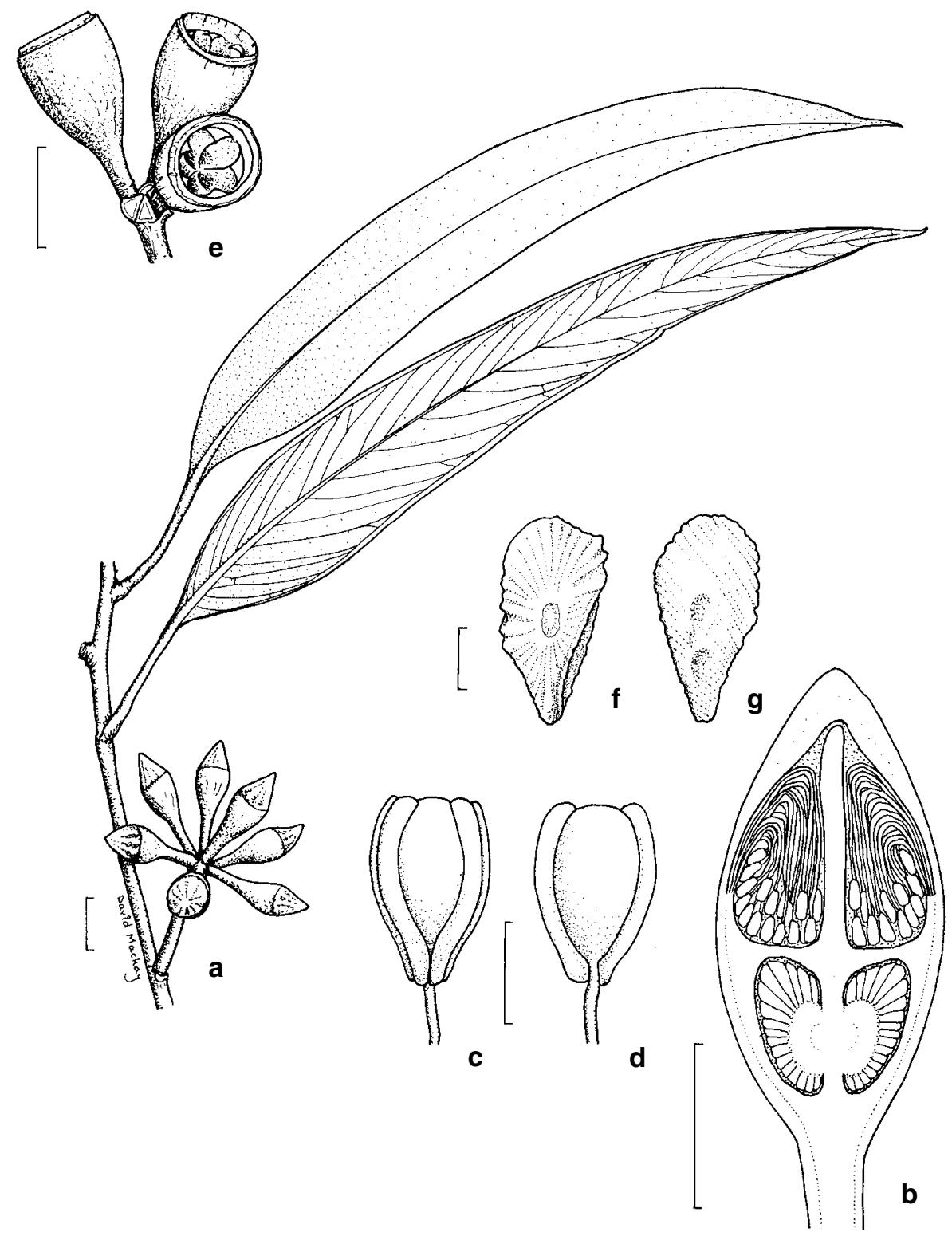

Fig. 24. E. assimilans. a, adult leaves, inflorescence and buds; $\mathbf{b}$, longitudinal section of bud. $\mathbf{c}$, $\mathbf{d}$, anther; $\mathbf{e}$, inflorescence and fruits; $\mathbf{f}, \mathbf{g}$, seed (from Hill 218). Scale bars: $\mathrm{a}, \mathrm{e}=1 \mathrm{~cm} ; \mathrm{b}=5 \mathrm{~mm}$; c, $\mathrm{d}=0.5 \mathrm{~mm} ; \mathrm{f}, \mathrm{g}=1 \mathrm{~mm}$. 
19. Eucalyptus infracorticata L.A.S. Johnson $\mathcal{E}$ K.D. Hill, sp. nov.

Habitus 'malleeformis' (multicaulis); cortex in regione basali (usque ad medium trunci) persistens, quasi-fibrosa; ramuli et alabastri glauci. Affinitates aliquanto incertae, forsan E. striaticalycis affinis, sed calyptra laevi et hemisphaerica differt. Alternative aliquanto assimulat E. sheathianam quae cortice toto laevi longe decorticanti differt.

Type: Western Australia: $8.6 \mathrm{~km} \mathrm{~S}$ of Queen Victoria Spring on Cundeelee track, K.D. Hill 2648 E L.A.S. Johnson, 30 Oct 1986 (holo NSW; iso PERTH).

Mallee. Bark persistent on lower to half trunk, finely fibrous-flaky, pale grey, yellow-brown under. Twigs glaucous. Juvenile leaves not known. Adult leaves disjunct, broad-lanceolate, dull, $6-11 \mathrm{~cm}$ long, $1.5-2.5 \mathrm{~cm}$ wide; petioles terete, $1.5-3.0 \mathrm{~cm}$ long; lateral veins distinct, regular, moderately spaced, at $30-45^{\circ}$ to midrib; reticulation incomplete; intramarginal vein continuous, distinct, within $0.5 \mathrm{~mm}$ of margin. Umbellasters simple, axillary, 7-11-flowered. Peduncles terete or ribbed, 8-15 mm long. Pedicels terete or slightly angled, 2-5 mm long. Buds glaucous, pyriform, 9-10 mm long, 5-6 mm diam.; calyptra shorter than hypanthium, as wide as hypanthium and lacking any constriction at the join, not striate, hemispherical. Fruits cylindrical, 4-5 locular, 7-9 mm long, 5-6 mm diam.; calyptra scar and stemonophore flat, narrow (less than $0.5 \mathrm{~mm}$ wide); disc initially raised but sharply incurved and depressed for most of width, 1.5-2 mm wide (Fig. 26).

Diagnosed as follows: mallee; bark persistent on lower trunk; adult leaves dull; twigs and buds glaucous. Relationships are unclear, but it may be allied to E. striaticalyx W.V. Fitzg., from which it is distinguished by the smooth hemispherical calyptra. Alternatively, there are resemblances to E. sheathiana, which differs in the wholly smooth bark shedding in long streamers.

Known only from a small population at the type locality (Fig. 27).

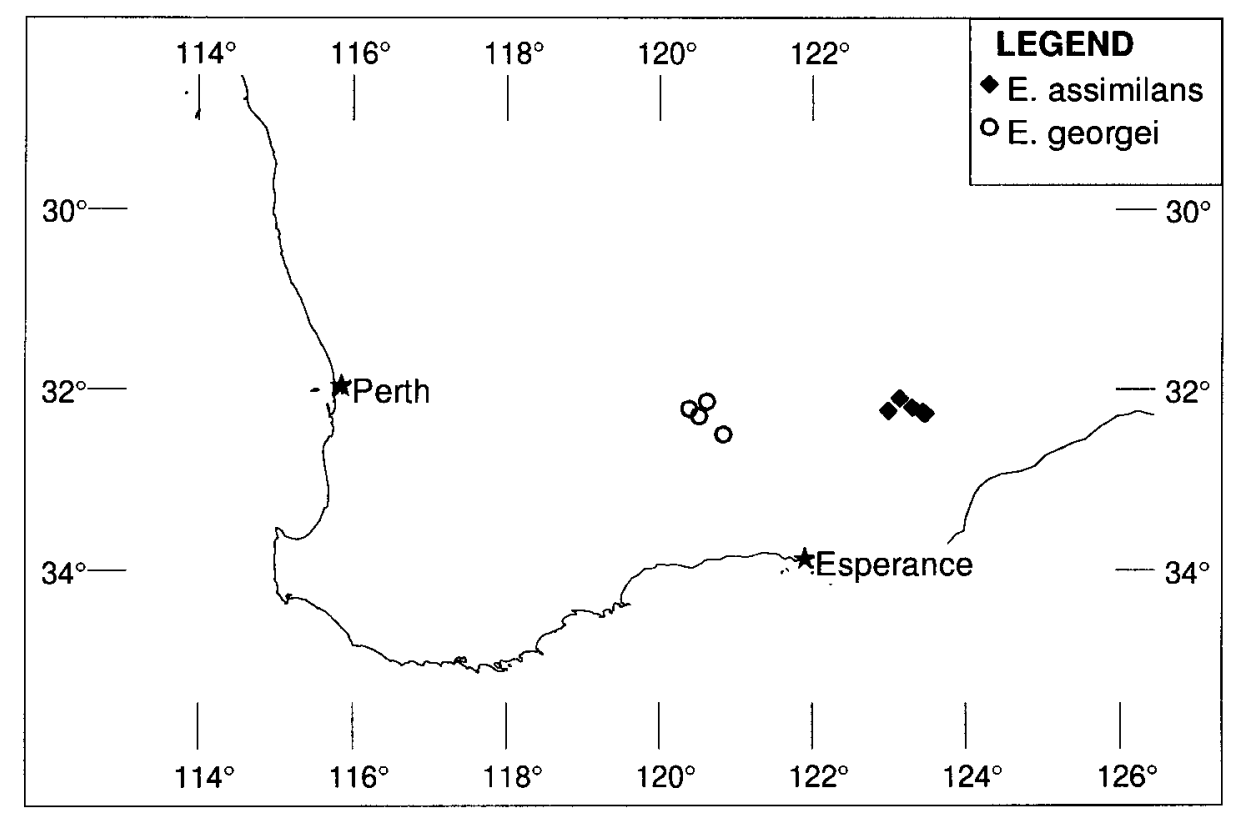

Fig. 25. Distribution of E. assimilans, E. georgei. 


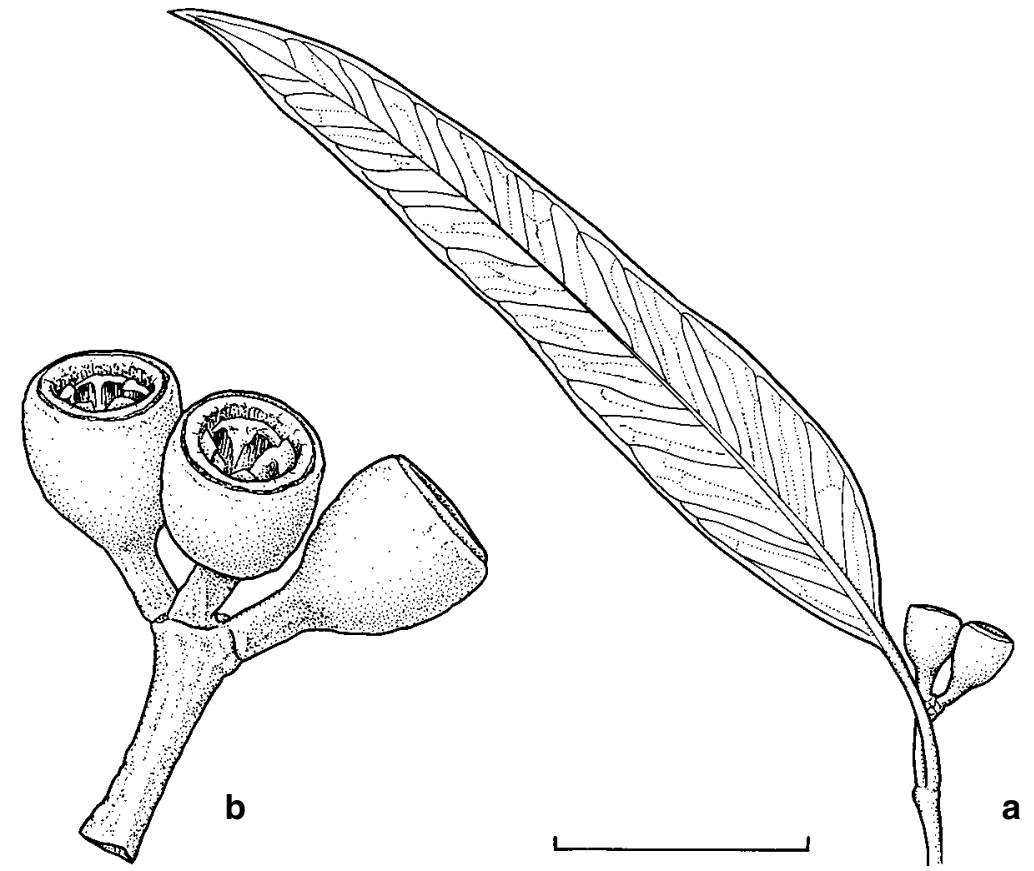

Fig. 26. E. infracorticata. a, adult leaf, inflorescence and fruits; $\mathbf{b}$, inflorescence and fruits (from Hill 2684B). Scale bar $=1 \mathrm{~cm}$.

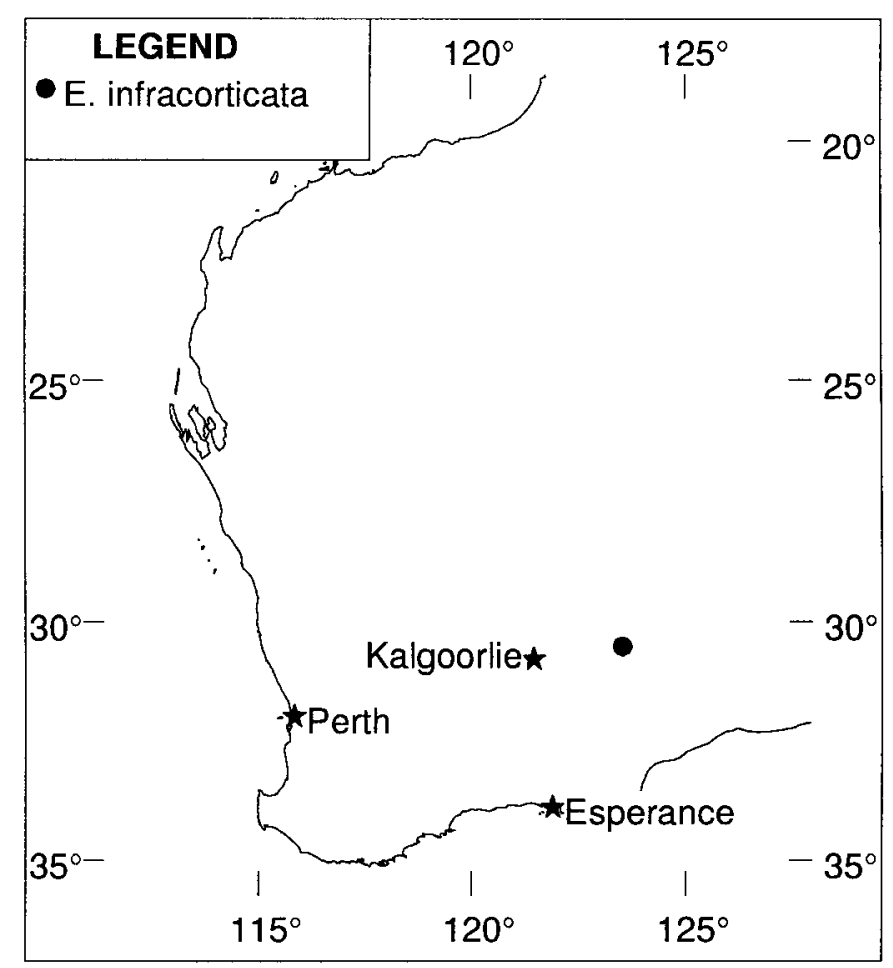

Fig. 27. Distribution of E. infracorticata. 
This species occurs in open mallee shrubland with Triodia understorey on red sandy desert loam.

Conservation status: not sufficiently known (K).

The epithet is from the Latin infra, below, and corticatus, covered with bark, from the persistent bark over the lower trunk.

Specimens examined: Western Australia: $8.6 \mathrm{~km} \mathrm{~S}$ of Queen Victoria Spring on Cundeelee track, Hill 2684B \& Johnson, 30 Nov 1986 (NSW).

\section{The Eucalyptus kondininensis complex}

There are four recognisable entities in this group. These could conservatively be treated as a single species, but this would take no account of differences in habitat and morphology (see Table 11). Three of the four were included in E. polita by Brooker and Hopper (1993), based solely on the bark differences from E. kondininensis. We here choose to treat them as four separate, although closely related, species. Three of the four occur in the undeveloped country east of Hyden, south of Southern Cross and west of the Coolgardie-Esperance road. They are consequently little-collected and poorly understood in the field.

20. Eucalyptus kondininensis Maiden \& Blakely, J. \& Proc. Roy. Soc. New South Wales 59: 189, (1925).

Type citation: 'Collected at Kondinin, between Bendering and Gnarming, on loam flats forming open forest with E. salmonophloia and E. flocktoniae (C. A. Gardner, Nos. 1843 and 1966).'

Type: syn NSW; isosyn K (1966), MEL (1843), PERTH (1843 \& 1966).

Tree to $15 \mathrm{~m}$ tall. Bark smooth, pale grey with grey, brown and pink streaks, shedding in long ribbons, with a clearly defined scaly black persistent stocking to up to $4 \mathrm{~m}$. Juvenile leaves disjunct, ovate, subglaucous. Adult leaves disjunct, narrow-lanceolate to lanceolate, strongly glossy, 5-12 cm long. $0.7-1.5 \mathrm{~cm}$ wide; petioles slightly channelled, $1.0-2.0 \mathrm{~cm}$ long; lateral veins indistinct, regular, at $30-40^{\circ}$ to midrib; intramarginal vein indistinct, continuous, within $1 \mathrm{~mm}$ of margin. Inflorescences simple, axillary. Umbellasters 7-flowered. Peduncles angular, 4-10 mm long. Buds and fruits sessile or shortly pedicellate, pedicels to $2 \mathrm{~mm}$ long. Mature buds ovoid to fusiform, 6-8 mm long, c. $4 \mathrm{~mm}$ diam.; calyptra conical, often distinctly apiculate, about as long as hypanthium, as wide as hypanthium, but slightly narrowed at junction, distinctly regularly ribbed; hypanthium indistinctly ribbed or smooth. Fruits cup-shaped to obconical, 3-4-locular, 4-6 mm long, 4-6 mm diam.; calyptra scar and stemonophore slightly raised, less than $0.5 \mathrm{~mm}$ wide; disc level or slightly depressed, ultimately incurved, c. $1 \mathrm{~mm}$ wide; valves broadly triangular, rim-level (Fig. 28).

Diagnosed as follows: tree with a clearly defined black stocking of persistent bark; leaves glossy; buds and fruits not glaucous; fruits conical to cup-shaped, sessile or subsessile (see also Table 11). Fruits tend to be pedicellate and conical in the north of the range, becoming cup-shaped and sessile in the south.

Known from the Kondinin district to Lake Magenta and Lake King (Fig. 29).

Restricted to low sites on heavy pale grey calcareous loams, often near salt lakes.

E. kondininensis is a 'blackbutt', but its affinities are not with the other blackbutt taxa in the Obtusiflorosae, E. clelandii and E. lesouefii (which are related rather to E. striaticalyx), but with E. redimiculifera and its allies.

Conservation status: not considered to be at risk. 


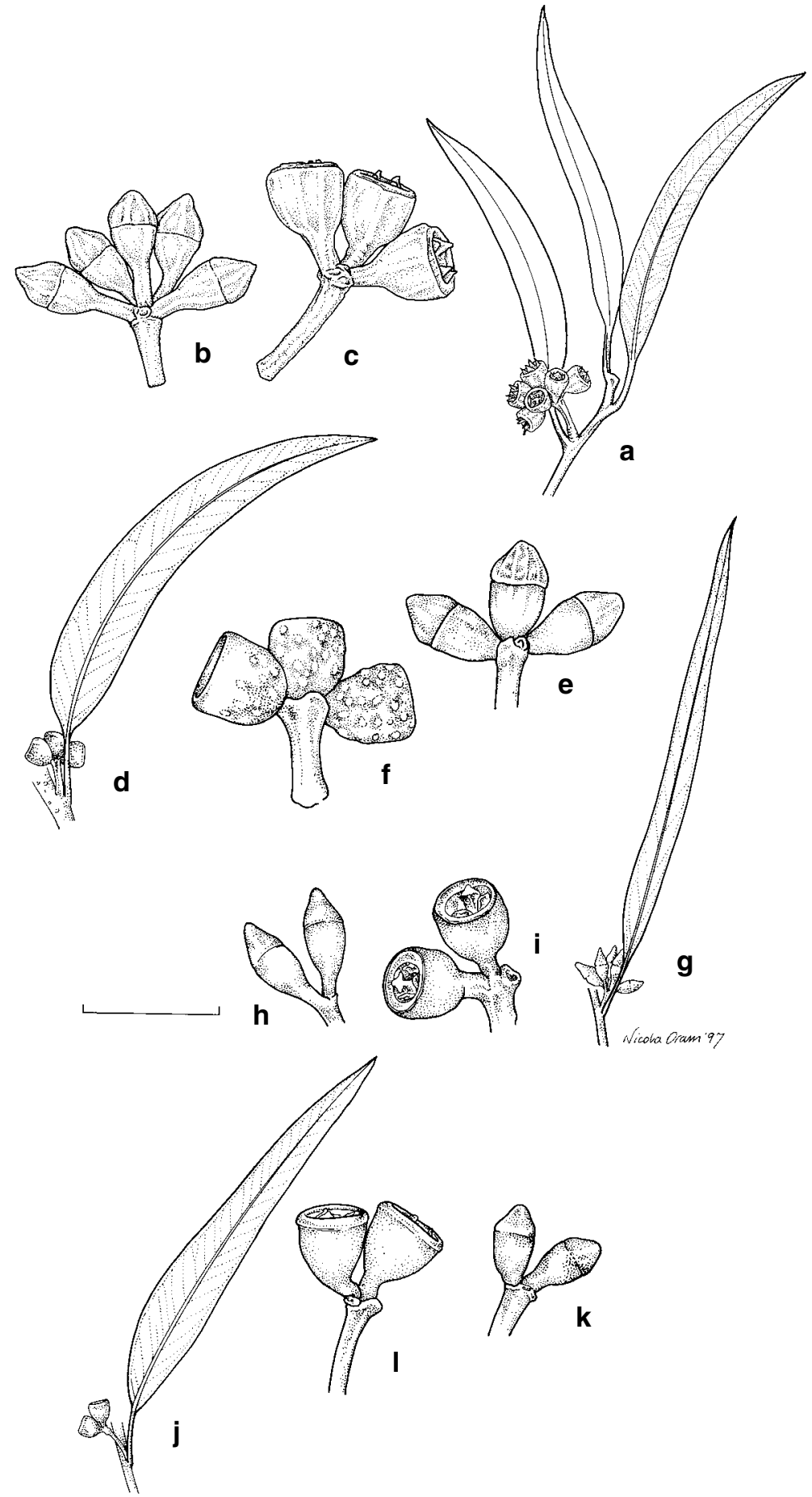

Fig. 28. E. polita. $\mathbf{a}$, adult leaf, inflorescence and fruits; $\mathbf{b}$, inflorescence and buds; $\mathbf{c}$, inflorescence and fruits ( from Johnson 9099B). E. paralimnetica. d, adult leaf, inflorescence and buds; e, inflorescence and buds; f, inflorescence and fruits (from Crisp 5954). E. redimiculifera. g, adult leaves, inflorescence and fruits; $\mathbf{h}$, inflorescence and buds; $\mathbf{i}$, inflorescence and fruits (from Gardner 11153). E. kondininensis. j, adult leaf, inflorescence and fruits; $\mathbf{k}$, inflorescence and buds; 1, inflorescence and fruits (from Gardner 1843). Scale bar: a, d, g, j= $3 \mathrm{~cm}, \mathrm{~b}, \mathrm{c}, \mathrm{e}, \mathrm{f}, \mathrm{h}, \mathrm{i}, \mathrm{k}, \mathrm{l}=1 \mathrm{~cm}$. 
Selected specimens (from 26 examined): Western Australia: ca. 1 miles [1.6 km] east of Buniche, Brooker 2278, 5 Nov 1969 (PERTH, NSW); 32.2 km west of Hyden towards Kondinin, Brooker 8362, 8 Nov 1983 (CANB, NSW); E side of Lake Magenta, on track, Brooker 8779, 14 Jan 1984 (CANB, NSW); 19.8 km north-west of Varley turnoff towards Hyden, Brooker 8889, 13 Mar 1985 (CANB, NSW); Lake Pallarup, south side, Brooker 8895, 21 Mar 1985 (CANB, NSW); Soldiers Road, E of Narembeen, Brooker 9635, 8 May 1987 (CANB, NSW); 9.3 km from Brookton to Corrigin Road on Quairading Road, Brooker 9710, 15 July 1987 (CANB, NSW); 2.7 km from Wickepin towards Pingelly, Brooker 9830, 16 Dec 1987 (CANB, NSW); 1 km N of Lake Bryde Road on Needilup Road, Brooker 10006, 21 July 1988 (CANB, NSW); corner Tincurrin Nth Road and Stock Route 3, c. 20 km W of Harrismith, Brooker 10141, 12 Dec 1988 (CANB, NSW); 1.5 miles [2.4 km] E of Newdegate, Chippendale 226, 17 Mar 1967 (CANB, NSW); S side of Kondinin township, Chippendale 260, 10 Aug 1967 (CANB, NSW); 8 km W of Lake Grace town, E edge of Lake, Crisp 5541, 5542, 28 Jan 1979 (CANB, NSW, PERTH); Kondinin, Gardner 1843, 30 Oct 1922 (PERTH, NSW); Pingrup, Gardner 10310, 22 Feb 1952 (PERTH, NSW); 3.4 km W of Lake King township on rd to Lake Grace, Hill 320, Johnson \& Blaxell, 22 Oct 1983 (NSW); $31.8 \mathrm{~km} \mathrm{~W}$ of Hyden on rd to Kondinin, Hill 642, 8 Nov 1983 (NSW); $0.9 \mathrm{~km} \mathrm{~S}$ of Brookton to Corrigin rd on Dudinin rd, Hill 2984, 31 Aug 1988 (NSW); S side of Lake Varley, $6.7 \mathrm{~km}$ W of Lake King to Hyden rd on Holt Rock to Kulin rd, Johnson $9186 \mathcal{E}$ B. Briggs, 1 Nov 1988 (NSW, CANB).

21. Eucalyptus polita Brooker \& Hopper, Nuytsia 9: 51 (1993).

Type: Western Australia: $62.7 \mathrm{~km}$ west of Mt Day road on Hyden-Norseman track (32²1'S 11954'E), M.I.H. Brooker 8361, 7 Nov 1983 (holo PERTH; iso AD, CANB, MEL, NSW).

Tree to $12 \mathrm{~m}$ tall. Bark smooth, pale grey and pink, shed in long ribbons, with a irregular scaly black persistent stocking on older plants. Juvenile leaves disjunct, ovate, subglaucous, to $7 \mathrm{~cm}$ long, $4 \mathrm{~cm}$ wide, petioles to $1.5 \mathrm{~cm}$ long. Adult leaves

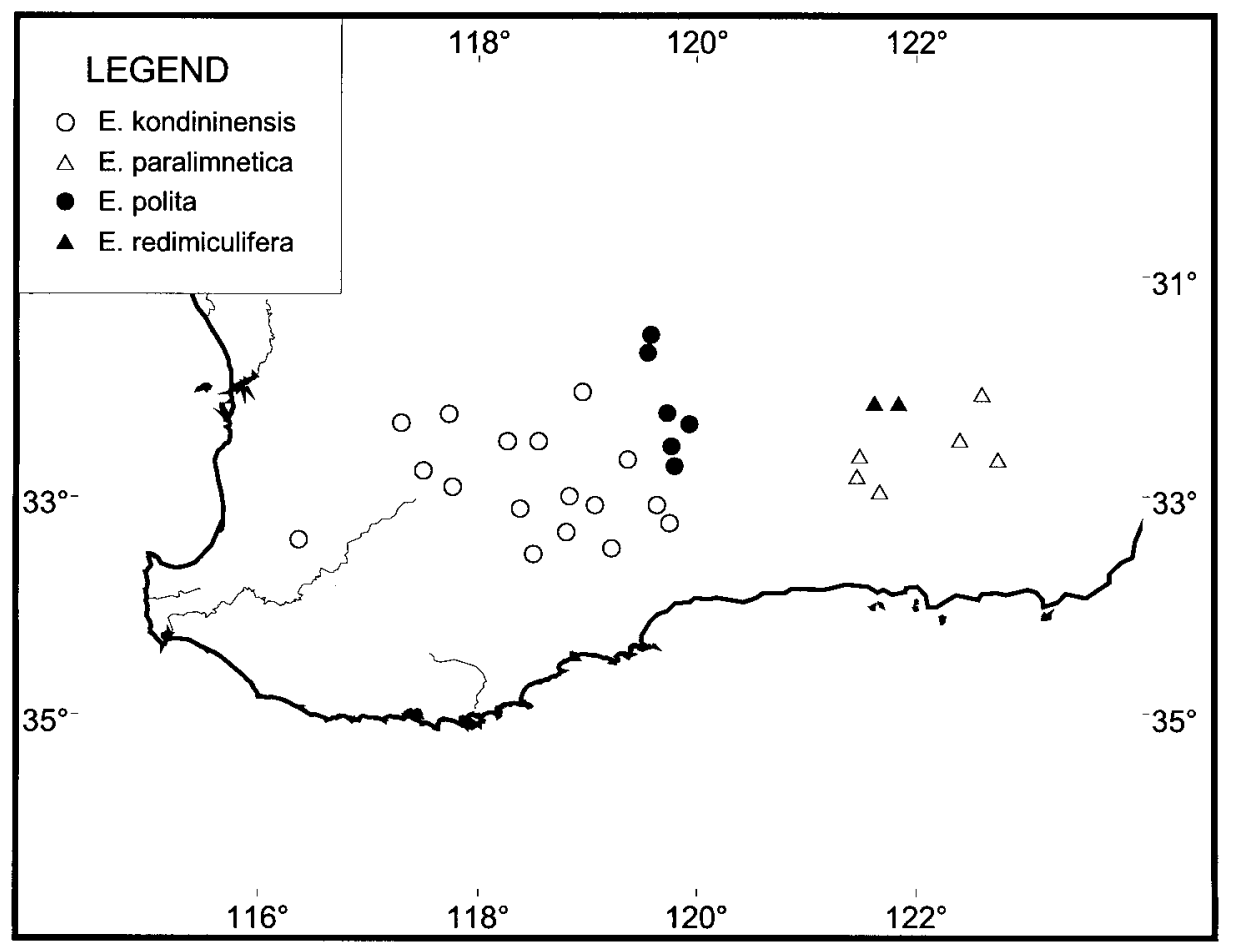

Fig. 29. Distribution of E. kondininensis, E. paralimnetica, E. polita, E. redimiculifera. 
disjunct, lanceolate, strongly glossy, 5-10 cm long. $0.8-1.8 \mathrm{~cm}$ wide; petioles slightly channelled, $0.7-1.8 \mathrm{~cm}$ long; lateral veins indistinct, regular, at $30-40^{\circ}$ to midrib; intramarginal vein indistinct, continuous, within $1 \mathrm{~mm}$ of margin. Inflorescences simple, axillary. Umbellasters (3-)7-flowered. Peduncles angular, 5-10 mm long. Buds and fruits sessile. Mature buds ovoid, 6-8 mm long, 4-5 mm diam.; calyptra inflated conical, about as long as or slightly shorter than hypanthium, as wide as hypanthium or slightly wider, but slightly narrowed at junction, distinctly regularly ribbed; hypanthium smooth to indistinctly ribbed. Fruits obconical to campanulate, 3-4-locular, 4-7 mm long, 4-6 mm diam.; calyptra scar and stemonophore slightly raised, less than $0.5 \mathrm{~mm}$ wide; disc level or slightly depressed, ultimately incurved, c. $1 \mathrm{~mm}$ wide; valves broadly triangular, rim-level or with remnants of style exserted (Fig. 28).

Diagnosed as follows: tree; bark smooth or persistent in a short stocking; adult leaves glossy; fruits conical to campanulate, sessile (see also Table 11).

The circumscription by Brooker and Hopper in the protologue included the taxa described below as E. redimiculifera and E. paralimnetica, and the illustrations more reflect these taxa than E. polita. Distinguishing features of E. redimiculifera and E. paralimnetica are given below and in Table 6 .

Known from the Forrestania district and some distance north and east of there (Fig. 29). The known distribution is very sporadic in poorly-explored country, and this taxon is probably more widespread.

Locally abundant but restricted in extent, in mallet woodlands on red lateritic loam or clay-loam. This contrasts to the habitat of E. kondininensis, usually on calcareous substrates, often around salt pans.

Conservation status: rare, although not under immediate threat (2R).

Selected specimens (from 9 examined): Western Australia: $10 \mathrm{~km} \mathrm{~S}$ of Marvel Loch (SE of Southern Cross) on road to Hyden, Blaxell 1728, Pryor \& J. Briggs, 13 Sep 1978 (NSW, PERTH); 62.7 $\mathrm{km}$ west of Mt Day road on Hyden to Norseman track, Brooker 8361, 7 Nov 1983 (CANB, NSW); $0.7 \mathrm{~km} \mathrm{~S}$ of Cross-roads, E of Hyden, Brooker 9570, 28 Jan 1987 (CANB, NSW); $187 \mathrm{~km} \mathrm{~W}$ of Norseman to Coolgardie rd on track to Hyden, Hill 637, Johnson, Blaxell, Brooker E Hopper, 7 Nov 1983 (NSW); $184.5 \mathrm{~km} \mathrm{~W}$ of Norseman to Coolgardie rd on Hyden track (13.3 km E of crossroads), Hill 2877, 26 Aug 1988 (NSW); $8.4 \mathrm{~km} \mathrm{~N}$ of Coolgardie to Hyden rd on Varley to Southern Cross rd, Hill 2883, 26 Aug 1988 (NSW); $91.6 \mathrm{~km}$ north of Coolgardie to Hyden road on Varley to Southern Cross road, Hill 2906, 26 Aug 1988 (NSW, CANB, PERTH); 7.8 km east of Rabbit Proof Fence on Varley to Southern Cross road, Hill 3054, 1 Sep 1988 (NSW, CANB, PERTH); $13.5 \mathrm{~km} \mathrm{~N}$ of Varley crossroads on Southern Cross rd, Hill 3061, 1 Sep 1988 (NSW); $98.5 \mathrm{~km}$ east of Hyden on Hyden to Norseman road (ie $11.7 \mathrm{~km}$ east of Crossroads), Johnson 9099B \& Johnson, 17 May 1988 (NSW, PERTH).

\section{Eucalyptus paralimnetica L.A.S. Johnson $\mathcal{E}$ K.D. Hill, sp. nov.}

Arbor; cortex toto laevis, longe decorticans; folia adulta nitida, linearia ad angustolanceolata; fructus cupuliformes brevipedicellati.

Type: Western Australia: $8.3 \mathrm{~km}$ from highway on Peak Charles road $\left(32^{\circ} 46^{\prime} \mathrm{S}\right.$ $1^{\circ} 1^{\circ} 8^{\prime}$ E), K.D. Hill 2318, L.A.S. Johnson E D.F. Blaxell, 8 Nov 1986 (holo NSW, iso CANB, MEL, PERTH).

Tree to $10 \mathrm{~m}$ tall. Bark smooth, pale pink-grey, shed in long ribbons. Juvenile leaves disjunct after node 6 , ovate, becoming narrow-lanceolate by node 8 , subglaucous. Adult leaves disjunct, linear to narrow-lanceolate, strongly glossy, 5-10 cm long. $0.5-1.1 \mathrm{~cm}$ wide; petioles slightly channelled, $1.0-1.5 \mathrm{~cm}$ long; lateral veins indistinct, regular, at $40-50^{\circ}$ to midrib; intramarginal vein indistinct, continuous, within $0.5 \mathrm{~mm}$ of margin. Inflorescences simple, axillary. Umbellasters 7-flowered. Peduncles angular, 
5-8 mm long. Pedicels angular, 1-4 mm long. Mature buds ovoid, 6-7 mm long, c. $3 \mathrm{~mm}$ diam.; calyptra inflated conical, about as long as hypanthium, as wide as hypanthium but slightly narrowed at junction, distinctly regularly ribbed; hypanthium indistinctly ribbed. Fruits cup-shaped, 3-4-locular, 4-5 mm long, 4-5 mm diam.; calyptra scar and stemonophore slightly raised, less than $0.5 \mathrm{~mm}$ wide; disc level or slightly depressed, ultimately incurved, c. $1 \mathrm{~mm}$ wide; valves broadly triangular, rim-level (Fig. 28).

Diagnosed as follows: tree; bark wholly smooth; adult leaves strongly glossy; fruits cup-shaped, shortly pedicellate (see also Table 11).

At present known from a band of country from around Peak Charles to the southern extension of the Fraser Range (Fig. 29). Known distribution is very sporadic but in remote country, and future extensions of range are likely.

A locally common species in open woodland on pale brown calcareous loam, often at the edges of salt pans.

Conservation status: not considered to be at risk.

The epithet is from the Greek, para, beside, and limneticos, relating to lakes, in reference to the occurrence adjacent to salt lakes.

Selected specimens (from 8 examined): Western Australia: on Telegraph line, $\mathrm{S}$ of Fraser Range W of Norseman, Beard 6317, 13 Sep 1970 (KPBG, NSW); between Clear Streak and Double Tank on an old track from Fraser Range to Esperance, Beard 6325, 13 Sep 1970 (KPBG, NSW); c. 109 km W of Balladonia (81.5 km E of Norseman), Brooker 6458, 22 Aug 1979 (CANB, NSW); c. 55 km SSW of Norseman, $5 \mathrm{~km}$ from highway towards Peak Charles, Crisp 5954, 20 Sep 1979 (CANB, MEL, NSW, PERTH); $107.6 \mathrm{~km} \mathrm{~W}$ of Balladonia roadhouse on highway, Hill 2832, 24 Aug 1988 (NSW, CANB, PERTH).

23. Eucalyptus redimiculifera L.A.S. Johnson $\mathcal{E}$ K.D. Hill, sp. nov.

Arbor; cortex toto laevis; folia adulta obscura vel plus minusve nitida; ramuli, alabastra et fructus aliquantulo pruinosi; alabastra distincte pedicellata; fructus mediocres (ad $7 \times 6 \mathrm{~mm})$, ovoidei.

Type: Western Australia: $5.6 \mathrm{~km}$ west of highway on track turning off $11 \mathrm{~km}$ north of Norseman, K.D. Hill 589, L.A.S. Johnson, D.F. Blaxell, M.I.H. Brooker E S.D. Hopper, 6 Nov 1983 (holo NSW; iso CANB, PERTH).

Tree to $10 \mathrm{~m}$ tall. Bark smooth, white, pale grey and pink, shed in long ribbons. Juvenile leaves disjunct, broad-lanceolate, subglaucous, to $9 \mathrm{~cm}$ long, $2.5 \mathrm{~cm}$ wide, petioles to $0.8 \mathrm{~cm}$ long. Branchlets, buds and fruits weakly pruinose. Adult leaves disjunct, lanceolate, dull to semi-glossy, $4-10 \mathrm{~cm}$ long. $0.6-1.2 \mathrm{~cm}$ wide; petioles slightly channelled, $0.7-1.8 \mathrm{~cm}$ long; lateral veins indistinct, regular, at $30-50^{\circ}$ to midrib; intramarginal vein indistinct, continuous, within $0.5 \mathrm{~mm}$ of margin. Inflorescences simple, axillary. Umbellasters 7-flowered. Peduncles angular, 4-11 mm long. Pedicels 2-4 mm long. Mature buds ovoid, 6-7 mm long, c. $4 \mathrm{~mm}$ diam.; calyptra hemispherical, slightly shorter than hypanthium, as wide as hypanthium slightly narrowed at junction, distinctly regularly ribbed; hypanthium indistinctly ribbed. Fruits ovoid, 3-4-locular, 5-7 mm long, 5-6 mm diam.; calyptra scar and stemonophore slightly raised, c. $1 \mathrm{~mm}$ wide; disc level or slightly depressed, c. $1 \mathrm{~mm}$ wide; valves broadly triangular, steeply raised, tips vertically exserted but fragile and usually broken at rim-level (Fig. 28).

Diagnosed as follows: tree; bark wholly smooth; adult leaves dull to semiglossy; slight pruinosity present on twigs, buds and fruits; buds distinctly pedicellate; fruits medium (to $7 \times 6 \mathrm{~mm}$ ), ovoid (see also Table 11). 
Table 11. The E. kondininensis complex (all measurements in $\mathrm{mm}$ )

\begin{tabular}{|c|c|c|c|c|}
\hline Habit & $\begin{array}{l}\text { E. kondininensis } \\
\text { tree }\end{array}$ & $\begin{array}{l}\text { E. polita } \\
\text { tree }\end{array}$ & $\begin{array}{l}\text { E. redimiculifera } \\
\text { tree }\end{array}$ & $\begin{array}{l}\text { E. paralimnetica } \\
\text { tree }\end{array}$ \\
\hline Bark (stocking) & + & + & - & - \\
\hline Juvenile leaves & ovate & ovate & broad-lanceolate & broad-lanceolate \\
\hline Adult leaves & glossy & glossy & $\begin{array}{l}\text { dull semi- } \\
\text { glossy }\end{array}$ & glossy \\
\hline - size $(L \times B)$ & $50-120 \times 7-15$ & $50-100 \times 8-18$ & $40-100 \times 6-15$ & $50-100 \times 5-11$ \\
\hline Pruinosity & - & - & + & - \\
\hline Petiole (L) & $10-20$ & $7-18$ & $7-18$ & $10-15$ \\
\hline Peduncle (L) & $4-10$ & $5-10$ & $4-11$ & $5-8$ \\
\hline Pedicel (L) & $0-2$ & 0 & $2-4$ & $1-4$ \\
\hline \multicolumn{5}{|l|}{ Buds } \\
\hline - size $(L \times B)$ & $6-8 \times 4$ & $6-8 \times 4-5$ & $6-7 \times 4$ & $6-7 \times 3$ \\
\hline Fruits & cup to conical & $\begin{array}{l}\text { conical to } \\
\text { campanulate }\end{array}$ & ovoid & cup \\
\hline - size $(\mathbf{l} \times \mathbf{b})$ & $4-6 \times 4-6$ & $4-7 \times 4-6$ & $5-7 \times 5-6$ & $4-5 \times 4-5$ \\
\hline
\end{tabular}

Gardner had distinguished this species as new and a specimen with his manuscript name 'redimiculiphloia' is in NSW (Gardner 11153). Since Gardner's name is a mixture of Greek and Latin, we have coined the new name 'redimiculifera', from the Latin, redimiculum, a band or fetter, and -fera, bearing, referring to the 'bracelets' of shed bark encircling the twigs and smaller branches

Known from a few scattered populations near Norseman (Fig. 29).

Locally abundant in open woodland on heavy, calcareous loams.

Conservation status: restricted in occurrence and apparently nowhere in large stands, although no immediate threat is evident (2R).

Selected specimens (from 9 examined): Western Australia: ca. 6 miles [9.6 km] by road from the Norseman to Coolgardie road, 6.6 miles [10.6 k] from Norseman, Brooker 4539, 6 Apr 1974 (CANB, NSW); $5.5 \mathrm{~km}$ W of highway on track $15 \mathrm{~km} \mathrm{~S}$ of Hyden turnoff, Brooker 7060, 9 Nov 1981 (CANB, AD, MEL, NSW, PERTH); $5.6 \mathrm{~km} \mathrm{~W}$ of Coolgardie to Norseman road, Brooker 8349, 6 Nov 1983 (CANB, NSW); 8 miles [12.8 km] NW from Norseman, Gardner 11153, 6 Nov 1953 (CANB, NSW).

\section{Acknowledgments}

Thanks are due to Leonie Stanberg, who has provided extremely valuable technical and editorial assistance throughout the project, and prepared the maps. Also David Mackay, Nicola Oram and Lesley Elkan who prepared the illustrations, and Peter Wilson for editorial advice and assistance with Latin diagnoses, as well as an anonymous referee for helpful critical comments.

\section{References}

Bentham, G. (1867) Flora Australiensis, vol. 3 (L. Reeve: London).

Blakely, W.F. (1934) A Key to the eucalypts (The Worker Press: Sydney).

Briggs, J.D. \& Leigh, J.H. (1996) Rare or Threatened Australian Plants (CSIRO: Collingwood, Vic.)

Brooker, M.I.H. (1971) Studies in the genus Eucalyptus, series Dumosae. Nuytsia 1: 210-216. 
Brooker, M.I.H. (1979) A new series based on seed characters in the informal section Dumaria Pryor and Johnson of the Genus Eucalyptus. Aust. For. Res. 9: 185-188.

Brooker, M.I.H. (1981) A new series Ovulares, of the genus Eucalyptus based on the subseries Ovularinae Pryor \& Johnson. Brunonia 4: 1-26.

Brooker, M.I.H. (2000) A new classification of the Genus Eucalyptus L.Hér. (Myrtaceae). Austral. Syst. Bot. 13: 79-148.

Brooker, M.I.H. \& Hopper, S.D. (1979) A taxonomic revision of Eucalyptus wandoo, E. redunca and allied species (Eucalyptus series Levispermae Maiden - Myrtaceae) in Western Australia. Nuytsia 8: 1-189.

Brooker, M.I.H. \& Hopper, S.D. (1993) New series, subseries, species and subspecies of Eucalyptus (Myrtaceae) from Western Australia and from South Australia. Nuytsia 9: 1-68.

Brooker, M.I.H. \& D.A. Kleinig (1990) Field guide to eucalypts, vol. 2 South-western and Southern Australia (Inkata Press: Melbourne).

Burbidge, N.T. (1947) Key to the South Australian species of Eucalyptus. Trans. Roy. Soc. South Australia 1: 137-163.

Carr, S.G.M. \& Carr, D.J. (1969) Oil glands and ducts in Eucalyptus L'Herit. I. The phloem and the pith. Austral. J. Bot. 17: 471-513.

Chippendale, G.M. (1988) Eucalyptus. In A.S. George (ed.), Flora of Australia, vol. 19 (AGPS: Canberra).

Gardner, C.A. (1960) Trees of Western Australia. Nos 47 to 54. J. Agric. Western Australia 47-54.

Hill, K.D. \& Johnson, L.A.S. (1994) Systematic studies in the eucalypts. 6. A revision of the coolibahs, Eucalyptus subgenus Symphyomyrtus section Adnataria series Oliganthae subseries Microthecosae (Myrtaceae). Telopea 5: 693-702.

Hill, K.D. \& Johnson, L.A.S. (1995) Systematic studies in the eucalypts. 7. A revision of the bloodwoods, genus Corymbia (Myrtaceae). Telopea 6: 185-504.

Luehmann, J.G. (1897) Victorian Naturalist 13: 147, 168.

Maiden, J.H. (1903-1933) A critical revision of the genus Eucalyptus (Govt. Printer: Sydney).

Maiden, J.H. (1911) J. Nat. Hist. Sci. Soc. Western Australia 3: 177 .

Mueller, F. (1882) Systematic census of Australian plants.

Mueller, F. (1884) Eucalyptographia X.

Mueller, F. (1889) Second systematic census of Australian plants.

Nicolle, D. (1997) A taxonomic revision of the Eucalyptus striaticalyx group (Eucalyptus series Rufispermae: Myrtaceae). Nuytsia 11(3): 365-382.

Pryor, L.D. \& L.A.S. Johnson (1971) A classification of the eucalypts (ANU Press: Canberra).

Manuscript received: 6 Jan 2000

Manuscript accepted: 1 Nov 2000 